Article

\title{
Self-Assembly of Antiferromagnetically-Coupled Copper(II) Supramolecular Architectures with Diverse Structural Complexities
}

\author{
Santokh S. Tandon ${ }^{1,2, * \mathbb{D}}$, Scott D. Bunge ${ }^{2}$, Neil Patel ${ }^{2}$, Esther C. Wang ${ }^{2}$ \\ and Laurence K. Thompson ${ }^{3}$ \\ 1 Department of Chemistry and Biochemistry, Kent State University-Salem Campus, Salem, OH 44460, USA \\ 2 Department of Chemistry and Biochemistry, Kent State University, Kent, OH 44242, USA; \\ sbunge@kent.edu (S.D.B.); neilnpatel89@gmail.com (N.P.); ewang2@kent.edu (E.C.W.) \\ 3 Department of Chemistry, Memorial University, St. John's Newfoundland, NL A1B 3X7, Canada; \\ laurie.thomp@gmail.com \\ * Correspondence: standon@kent.edu; Tel.: +1-330-337-4235 \\ Academic Editor: Catherine Housecroft \\ Received: 25 October 2020; Accepted: 23 November 2020; Published: 26 November 2020

\begin{abstract}
The self-assembly of 2,6-diformyl-4-methylphenol (DFMP) and 1-amino-2-propanol (AP)/2-amino-1,3-propanediol (APD) in the presence of copper(II) ions results in the formation of six new supramolecular architectures containing two versatile double Schiff base ligands $\left(\mathrm{H}_{3} \mathrm{~L}\right.$ and $\left.\mathrm{H}_{5} \mathrm{~L} 1\right)$ with one-, two-, or three-dimensional structures involving diverse nuclearities: tetranuclear $\left[\mathrm{Cu}_{4}\left(\mathrm{HL}^{2-}\right)_{2}\left(\mathrm{~N}_{3}\right)_{4}\right] \cdot 4 \mathrm{CH}_{3} \mathrm{OH} \cdot 56 \mathrm{H}_{2} \mathrm{O}(\mathbf{1})$ and $\left[\mathrm{Cu}_{4}\left(\mathrm{~L}^{3-}\right)_{2}(\mathrm{OH})_{2}\left(\mathrm{H}_{2} \mathrm{O}\right)_{2}\right](2)$, dinuclear $\left[\mathrm{Cu}_{2}\left(\mathrm{H}_{3} \mathrm{L1}^{2-}\right)\left(\mathrm{N}_{3}\right)\left(\mathrm{H}_{2} \mathrm{O}\right)\left(\mathrm{NO}_{3}\right)\right]$ (3), polynuclear $\left\{\left[\mathrm{Cu}_{2}\left(\mathrm{H}_{3} \mathrm{~L}^{2-}\right)\left(\mathrm{H}_{2} \mathrm{O}\right)\left(\mathrm{BF}_{4}\right)\left(\mathrm{N}_{3}\right)\right] \cdot \mathrm{H}_{2} \mathrm{O}\right\}_{\mathrm{n}}$ (4), heptanuclear $\left[\mathrm{Cu}_{7}\left(\mathrm{H}_{3} \mathrm{L1}^{2-}\right)_{2}(\mathrm{O})_{2}\left(\mathrm{C}_{6} \mathrm{H}_{5} \mathrm{CO}_{2}\right)_{6}\right] \cdot 6 \mathrm{CH}_{3} \mathrm{OH} \cdot 44 \mathrm{H}_{2} \mathrm{O}$ (5), and decanuclear $\left[\mathrm{Cu}_{10}\left(\mathrm{H}_{3} \mathrm{L1}^{2-}\right)_{4}(\mathrm{O})_{2}(\mathrm{OH})_{2}\left(\mathrm{C}_{6} \mathrm{H}_{5} \mathrm{CO}_{2}\right)_{4}\right]\left(\mathrm{C}_{6} \mathrm{H}_{5} \mathrm{CO}_{2}\right)_{2} \cdot 20 \mathrm{H}_{2} \mathrm{O}(6)$. X-ray studies have revealed that the basic building block in 1,3, and 4 is comprised of two copper centers bridged through one $\mu$-phenolate oxygen atom from $\mathrm{HL}^{2-}$ or $\mathrm{H}_{3} \mathrm{~L}^{2-}$, and one $\mu-1,1$-azido $\left(\mathrm{N}_{3}{ }^{-}\right)$ion and in 2,5 , and 6 by $\mu$-phenoxide oxygen of $\mathrm{L}^{3-}$ or $\mathrm{H}_{3} \mathrm{~L}^{2-}$ and $\mu-\mathrm{O}^{2-}$ or $\mu_{3}-\mathrm{O}^{2-}$ ions. H-bonding involving coordinated/uncoordinated hydroxy groups of the ligands generates fascinating supramolecular architectures with 1D-single chains (1 and 6), 2D-sheets (3), and 3D-structures (4). In 5, benzoate ions display four different coordination modes, which, in our opinion, is unprecedented and constitutes a new discovery. In $\mathbf{1}$, 3 , and $5, \mathrm{Cu}(\mathrm{II})$ ions in $\left[\mathrm{Cu}_{2}\right]$ units are antiferromagnetically coupled, with $\mathrm{J}$ ranging from -177 to $-278 \mathrm{~cm}^{-1}$.
\end{abstract}

Keywords: self-assembly of supramolecular architectures; antiferromagnetically-coupled copper(II) complexes; magneto-structural correlations; phenolate and azido bridged copper(II) complexes

\section{Introduction}

Self-assembly processes use simple building blocks in biological systems for the construction of symmetrical complex supramolecular biomolecules such as proteins, lipoproteins, DNA, glycoproteins, enzymes etc. [1-3]. Inspired by nature, in the last few decades, chemists have used the self-assembly methodology [4-6] to successfully generate a variety of supramolecular architectures including organic materials [7-9], metalacyclic polygons and polyhedrons [10], and nanoscale systems [11,12] with desirable sizes, shapes, and functions. The self-assembly technique, which utilizes a variety of cooperative and noncovalent interactions such as hydrogen bonding, strong electrostatic, and van der Walls forces, $\pi-\pi$ stacking, hydrophobic, hydrophilic, and metal-ligand interactions etc., has many advantages over the stepwise synthesis of large supramolecular assemblies. In these processes, 
the formation of the desired products from the building blocks occur spontaneously and efficiently in one pot. For the spontaneous self-assembly of supramolecular coordination complexes including 1D-, 2D-, and 3D-network structures and grids, appropriate precursor building blocks are reacted in the presence of metal ions as templates [13-23].

We successfully used the self-assembly process to produce spin-coupled coordination complexes of transition metal ions with macrocyclic [23-38] and noncyclic [39-43] Schiff base ligands to get a deeper insight into magneto-structural relationships, to understand the role of metal ions on the self-assembly and structural complexities of assemblies, and the effects of the anions on the formation and coordination abilities of the Schiff-base ligands. Our interest in this area stemmed from the implications of transition metal complexes in homogeneous catalysis [44-46] as enzyme models [47-50], and their potential applications in magnetic materials [51-55]. In the last three decades, many spin-coupled coordination complexes exhibiting ferromagnetic and antiferromagnetic behavior have been designed, synthesized and structurally characterized, and magneto-structural relationships have been investigated [56-88]. In spin coupled coordination clusters, the bridging ligands between metal centers play a central role on the nature and the magnitude of the magnetic spin exchange interactions. In addition to organic ligands, a variety of doubly, triply, or quadruply bridging anions like $\mathrm{N}_{3}{ }^{-}, \mathrm{RO}^{-}\left(\mathrm{R}=\mathrm{H}, \mathrm{C}_{6} \mathrm{H}_{5}, \mathrm{CH}_{3}\right.$ etc.), $\mathrm{N}(\mathrm{CN})_{2}{ }^{-}, \mathrm{CN}^{-}, \mathrm{NCS}^{-}, \mathrm{O}^{2-}, \mathrm{RCO}_{2}^{-}\left(\mathrm{R}=\mathrm{C}_{6} \mathrm{H}_{5}, \mathrm{CH}_{3}\right)$ are used often to generate extended network structures [89-94]. Due to the flexi-dentate nature and diverse coordination modes, hydroxy and azido are the most versatile anions for providing intra/interdimer bridges to generate supramolecular clusters and to propagate spin-exchange interactions between the metal centers [40,42,53,95-104].

In our earlier communications, we reported the self-assembly of 2,6-diformyl-4-alkyl(R)phenol ( $\mathrm{R}=\mathrm{CH}_{3}$, DFMP and $\left.\mathrm{R}=\mathrm{C}\left(\mathrm{CH}_{3}\right)_{3}, \mathrm{DFTBP}\right)$ with diamine/diamino alcohols in the presence of Lewis acids $\left(\mathrm{H}^{+} /\right.$transition metal ions) as a templating agent to generate metal free macrocycles [27] and coordination complexes of macrocyclic ligands with different nuclearities ranging from dinuclear [28,30,32,34,36] to tetranuclear/dimeric octanuclear [24-26,29,30,32,37], and hexanuclear/dimeric dodecanuclear clusters in which a single macrocycle incorporates six metal ions in a distorted boat-shaped 'benzene-like' array with three hydroxide ions in the central cavity [31,35], heptanuclear/dimeric tetradecanuclear body centered clusters with $\mathrm{Cu}^{2+}$ ion in the center of macrocyclic cavity [38], and dimeric dodecanuclear supramolecular metallo-clusters in which the central $\mathrm{BO}_{3}{ }^{3-}$ species is linked to six copper(II) ions held together by a single macrocyclic ligand through three $\mu 1,1-\mathrm{O}\left(\mathrm{BO}_{3}{ }^{3-}\right)$ and three $\mu 1,3-\mathrm{O}\left(\mathrm{BO}_{3}{ }^{3-}\right)$ bridges [23]. In continuation of our interest in the self-assembly of spin coupled transition metal complexes of cyclic/noncyclic Schiff-base ligands and our investigation of magneto-structural relationships, the effects of various anions and the transition metal ions on the self-assembly of supramolecular architectures with different nuclearities and structural complexities, and the formation and the coordination abilities of Schiff-base ligands, we have undertaken a systematic approach of reacting DFMP and various hydroxy-amines incorporating one, two, and three hydroxy groups. The self-assembly of DFMP and 2-aminoethanol in the presence of $\mathrm{Co}^{2+} / \mathrm{Ni}^{2+} / \mathrm{NaN}_{3}$ generates ferromagnetically-coupled tetranuclear and hexanuclear azide-bridged 1D single-chain coordination polymers [40], whereas in the presence of $\mathrm{Cu}^{2+} / \mathrm{NaN}_{3}$ antiferromagnetically-coupled copper coordination, polymers based on single-chain or sheet structures involving dinuclear and tetranuclear copper(II) units are produced [41]. One pot self-assembly reactions between DFMF and tris(hydroxymethyl)aminomethane (THMAM) in the presence of copper(II)/nickel(II)/ $\mathrm{NaC}_{6} \mathrm{H}_{5} \mathrm{CO}_{2} /\left(\mathrm{NaN}_{3}\right)$ produce an antiferromagnetically-coupled $\mathrm{Cu}$ (II) coordination polymer consisting of repeating pentanuclear units with a novel double-stranded ladder-like structure in which $\left[\mathrm{Cu}\left(\mathrm{N}_{3}\right)_{4}\right]^{2-}$ anions link single chains comprised of dinuclear cationic $\left[\mathrm{Cu}_{2}\left(\mathrm{H}_{5} \mathrm{~L}^{2-}\right)\left(\mu-\mathrm{N}_{3}\right)\right]^{+}$subunits, forming a 3D structure of interconnected ladders through $\mathrm{H}$ bonding [39,42] and ferromagnetically-coupled hexanuclear nickel(II) clusters [42]. One-pot self-assembly reactions of DFMF with 1-amino-2-propanol (AP) and 2-amino-1,3-propanediol (APD) in the presence of nickel(II)/ $\mathrm{NaN}_{3}$ give antiferromagnetically-coupled tetranuclear coordination complexes of nickel(II) with incomplete double cubane structural cores which form 1D-single 
chains, 2D-sheets, and 3D structures through a network of H-bonding [43]. The coordination versatility of the Schiff-base ligands $\mathrm{H}_{3} \mathrm{~L}$ (2,6-bis-\{(2-hydroxypropylimino)methyl\}-4-methylphenol), potentially pentadentate $\left(\mathrm{N}_{2} \mathrm{O}_{3}\right)$, trianionic ligand) and $\mathrm{H}_{5} \mathrm{~L} 1$ (2,2' - [(2-hydroxy-5-methyl-1,3-phenylene) bis (methylidynenitrilo)]-1,3-propanediol, potentially heptadentate $\left(\mathrm{N}_{2} \mathrm{O}_{5}\right)$, pentaanionic ligand) towards nickel(II) ions [43] has prompted us to explore the coordination chemistry of these ligands towards copper(II) ions. In this report, the synthesis, crystal structures, and magnetic properties of six new copper(II) coordination complexes of two double Schiff-base ligands $\mathrm{H}_{3} \mathrm{~L}$ and $\mathrm{H}_{5} \mathrm{~L} 1$ with diverse nuclearities $\left(\mathrm{Cu}_{2}, \mathrm{Cu}_{4}, \mathrm{Cu}_{7}, \mathrm{Cu}_{10}, \mathrm{Cu}_{n}\right)$ are presented. Variable temperature magnetic studies performed on three complexes $(1,3$, and 5$)$ revealed that the magnetic exchange interactions within dinuclear units are dominated by strong antiferromagnetic coupling ( $\mathrm{J}$ ranging from -177 to $-278 \mathrm{~cm}^{-1}$ ).

\section{Results and Discussion}

\subsection{Synthesis of the Complexes}

Herein, we report the self-assembly, structural characterization, and magnetic studies of six new copper(II) complexes of two very versatile double Schiff base ligands $\left(\mathrm{H}_{3} \mathrm{~L}\right.$ and $\left.\mathrm{H}_{5} \mathrm{~L} 1\right)$ with a high degree of conformational flexibility. Previously [43], we reported the H-bonding directed self-assembly of ferromagnetically-coupled tetranuclear nickel(II) complexes of Schiff-base ligands $\mathrm{H}_{3} \mathrm{~L}$ and $\mathrm{H}_{5} \mathrm{~L} 1$ with one-, two- and three dimensional structural complexities. Reactions of DFMP with 1-amino-2-propanol (AP) and 2-amino-1,3-propanediol (APD) in the presence of copper(II) salts, $\mathrm{CuX}_{2}\left(\mathrm{X}=\mathrm{CH}_{3} \mathrm{CO}_{2}{ }^{-}, \mathrm{NO}_{3}, \mathrm{Cl}, \mathrm{ClO}_{4}, \mathrm{BF}_{4}^{-}\right) / \mathrm{NaN}_{3} / \mathrm{TEA}$, under varied conditions in one-pot, self-assembly produced dinuclear (3), tetranuclear (1 and 2), heptanuclear (5), decanuclear (6), and polynuclear (4) copper(II) complexes of $\mathrm{H}_{3} \mathrm{~L}$ and $\mathrm{H}_{5} \mathrm{~L} 1$ ligands. These complexes grow into beautiful 1D-single chains, 2D-sheets, or 3D structures through network of H-bonding. Previously [41-43], we observed that the nature of the anions and the metal ions had remarkable effects on the self-assembly of polynuclear supramolecular clusters, on the structural complexities, and the coordination abilities of the ligands. In the presence of $\mathrm{Ni}(\mathrm{II})$ ions [42,43], initially formed double Schiff-base ligands $\left(\mathrm{H}_{5} \mathrm{~L} 1\right.$ and $\left.\mathrm{H}_{7} \mathrm{~L} 3\right)$ undergo metal catalyzed partial hydrolysis of the double Schiff-base ligands to produce tetranuclear $\left[\mathrm{Ni}_{4}\left(\mathrm{HL}^{-2}\right)_{2}\left(\mathrm{APD}^{-1}\right)_{2}\right]\left(\mathrm{ClO}_{4}\right)_{2}$ and hexanuclear $\left[\mathrm{Ni}_{6}\left(\mathrm{H}_{3} \mathrm{~L}^{-1}\right)_{2}\left(\mathrm{THMAM}^{2-}\right)_{2}\left(\mu-\mathrm{N}_{3}\right)_{4}\left(\mathrm{CH}_{3} \mathrm{CO}_{2}\right)_{2}\right]$ and $\left[\mathrm{Ni}_{6}\left(\mathrm{H}_{3} \mathrm{~L}^{-1}\right)_{2}\left(\mathrm{THMAM}^{2-}\right)_{2}\left(\mu-\mathrm{N}_{3}\right)_{4}\left(\mathrm{C}_{6} \mathrm{H}_{2} \mathrm{CO}_{2}\right)_{2}\right]$ complexes of mono Schiff-base ligands $\mathrm{H}_{3} \mathrm{~L} 5$ and $\mathrm{H}_{4} \mathrm{~L} 4$, respectively (Figure 1). Complexes 1, 3, and 4 exhibit the same type of $\left[\mathrm{Cu}_{2}\right]$ basic building block cemented by the phenoxide O-atom of the Schiff base and $\mu-1,1$-azido bridge which dimerizes or polymerizes producing tetranuclear or supramolecular architectures through a variety of alkoxide, methoxide, oxide, and azido bridges. In complexes 1 and $2, \mathrm{H}_{3} \mathrm{~L}$ holds two copper centers in close proximity forming dinuclear units in which $\mathrm{Cu}(\mathrm{II})$ ions are bridged by phenoxide oxygen and $\mu-1,1-\mathrm{N}_{3}(1) / \mu_{3}-\mathrm{OH}^{-}(2)$ bridges. The dinuclear units dimerize through two interdimer $\mu-1,1-\mathrm{N}_{3}$ bridges (1) or through two $\mu_{3}-\mathrm{OH}^{-}$and two $\mu_{3}-\mathrm{PhO}^{-}$ (intra/interdimer) bridges that form neutral centrosymmetric tetranuclear complex (2). In complexes 3 and $4, \mathrm{H}_{5} \mathrm{~L} 1$ holds two $\mathrm{Cu}(\mathrm{II})$ centers via phenoxide oxygen and $\mu-1,1-\mathrm{N}_{3}$ bridges that form dinuclear units which grow into 2D-Sheets (3)/1D-single chains (4), which are crosslinked to generate 3D-structures through a network of strong $\mathrm{H}$-bonding. In complexes 5 and $\mathbf{6}, \mathrm{H}_{5} \mathrm{~L} 1$ holds two $\mathrm{Cu}(\mathrm{II})$ ions through phenoxide oxygen and $\mu_{3}-\mathrm{O}^{2-} / \mu-\mathrm{OH}^{-}$bridges to form dinuclear units which are interconnected through benzoate $/ \mu_{3}-\mathrm{O}^{2-} / \mu-\mathrm{OH}^{-}$bridges to generate heptanuclear (5) and decanuclear (6) complexes, which are relatively rare nuclearities. In 5 , benzoate ions display 4 different coordination modes which, in our opinion, is unprecedented and constitutes a first report. In complex 6, decanuclear units are interconnected through $\mathrm{H}$-bonds producing a supramolecular 1D-single chains structure. 


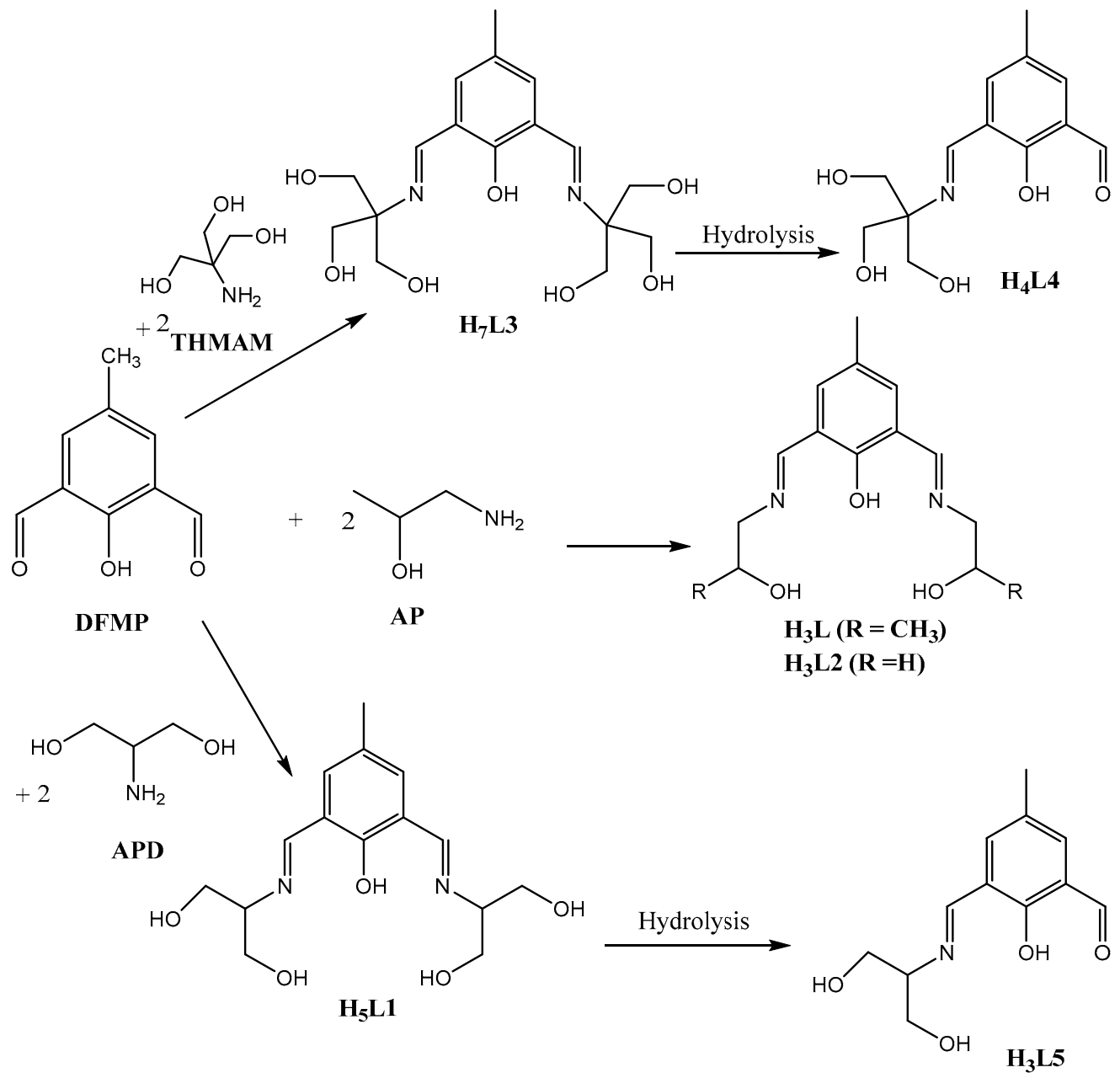

Figure 1. Structures of the Schiff base ligands. DFMP (2,6-diformyl-4-methylphenol), APD (2-amino-1,3-propanediol), AP (1-amino-2-propanol), and THMAM (tris(hydroxymethyl) amino methane).

\subsection{Description of Structures}

The $\mathrm{Cu}-\mathrm{N}$ and $\mathrm{Cu}-\mathrm{O}$ distances in the equatorial plane of all the complexes (1-6) reported in this paper fall in the ranges 1.888(13)-2.001(7) $\AA$ and 1.874(10)-2.038(4) $\AA$ (data Tables S1-S6), respectively, like other reported complexes with similar Schiff-base ligands [40-42,105-108]. The long axial $\mathrm{Cu}-\mathrm{O}$ distances lie in the range 2.337(2)-2.79(7) $\AA$. The $\mathrm{Cu}-\mathrm{Cu}$ separation in dinuclear units $\left(\mathrm{Cu}_{2}\right)$ of these complexes lies in the range 2.92(5)-3.09(2) $\AA$, similar to other dinuclear units in copper, cobalt and nickel complexes with Schiff-base ligands [40-42,105-108]. The $\mathrm{Cu}-\mathrm{Cu}$ distance between dinuclear units lies in the range 2.865(13)-3.58(1) , which, in some cases, is significantly longer than the intermetallic separation within dinuclear units, and is similar to that reported in similar tetranuclear copper(II) complexes [41].

\subsection{1. $\left[\mathrm{Cu}_{4}\left(\mathrm{HL}^{2-}\right)_{2}\left(\mathrm{~N}_{3}\right)_{4}\right] \cdot 4 \mathrm{CH}_{3} \mathrm{OH} \cdot 56 \mathrm{H}_{2} \mathrm{O}(\mathbf{1})$}

The molecular structure of centrosymmetric complex 1 is shown in Figure 2, together with relevant atomic labeling. Important bond distances and angles are listed in Table S1. In complex 1, $\mathrm{H}_{3} \mathrm{~L}$ acts as a tetradentate $\left(\mathrm{N}_{2} \mathrm{O}_{2}\right)$ dianionic ligand $\left(\mathrm{HL}^{2-}\right)$, binding through two imine nitrogen atoms, a deprotonated alkoxide oxygen in the side arm of the ligand, and a deprotonated phenoxide oxygen, bridging two copper(II) ions into a dinuclear unit. The alkoxy group on one side of the Schiff-base ligand remains protonated and uncoordinated. In each dinuclear unit, two copper(II) ions are bridged 
through a phenoxide oxygen and a $\mu-1,1-\mathrm{N}_{3}$ bridge. The link between $\left[\mathrm{Cu}_{2}\right]$ pairs is established via two end-on (EO) $\mu-1,1-\mathrm{N}_{3}$ bridges that form neutral centrosymmetric tetranuclear units, which are linked though remarkably strong H-bonds ( $2.688 \AA$ ) via protonated uncoordinated hydroxyl group $(\mathrm{HO}(3))$ in the side arm of the ligand forming single chains along the $a$-axis. A perspective view of the polymeric single chains along the $a$-axis is presented in Figure 3.

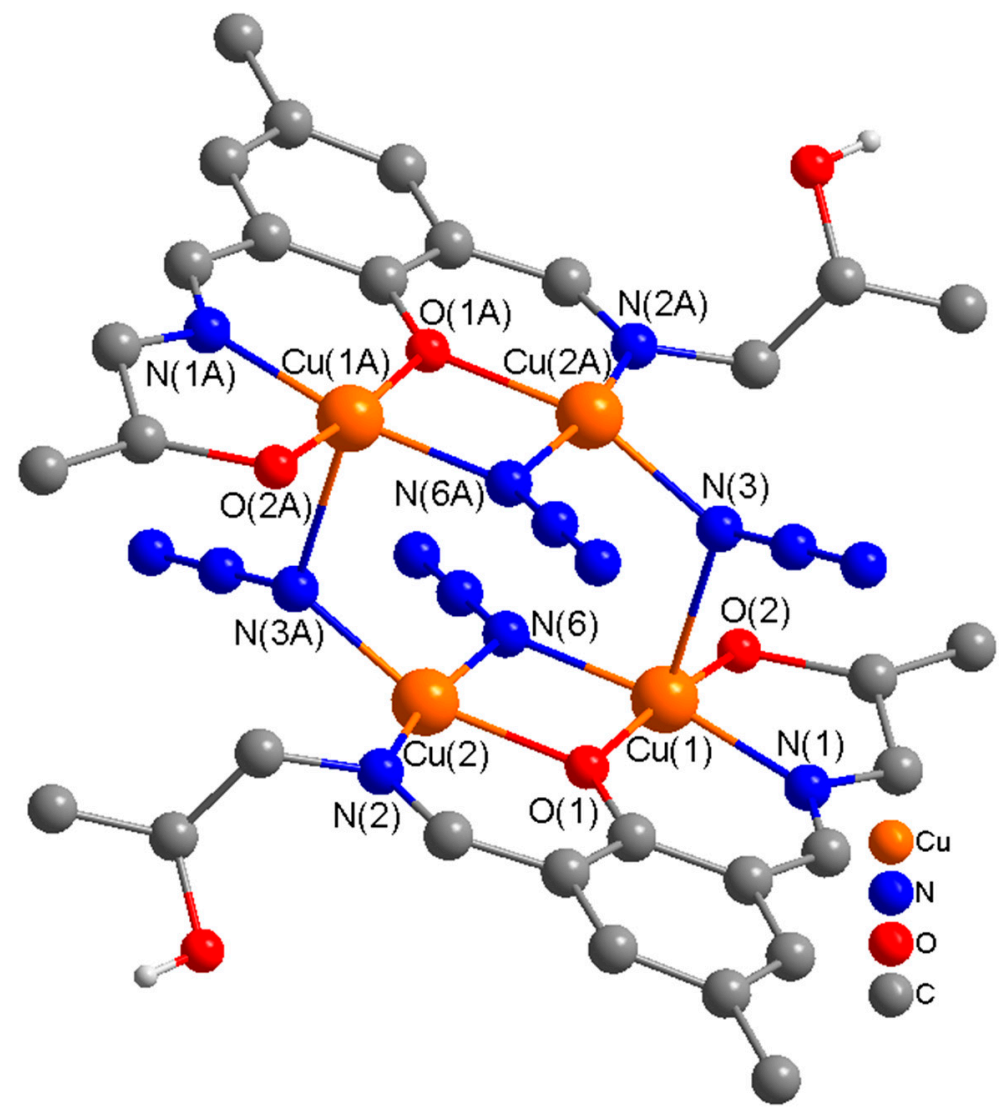

Figure 2. Molecular structure of a neutral centrosymmetric tetranuclear unit $\left[\mathrm{Cu}_{4}\left(\mathrm{HL}^{2-}\right)_{2}\left(\mathrm{~N}_{3}\right)_{4}\right](\mathbf{1})$ with numbering of atoms in the coordination environment. $\mathrm{H}$ atoms and solvent molecules are omitted for clarity. Atoms with A in their labels are symmetry generated.

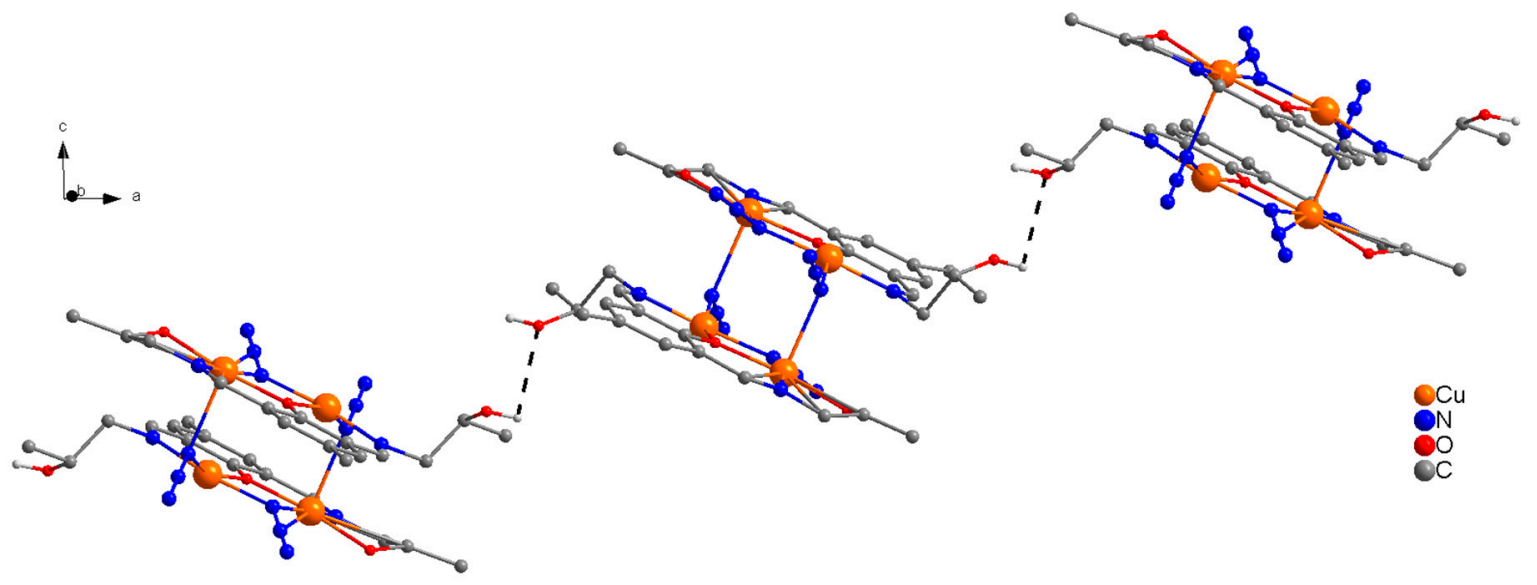

Figure 3. Perspective view of the crystal packing of $\mathbf{1}$ as seen along the $a$-axis generating $1 \mathrm{D}$-single chains via protonated uncoordinated hydroxy groups in the side arm of the ligands.

The stereochemistry at $\mathrm{Cu}(1)$ in an asymmetric dinuclear unit can best be described as distorted square pyramidal with a phenoxide $\mathrm{O}$, imine $\mathrm{N}$, alkoxide $\mathrm{O}$, and an azido nitrogen atom in the 
equatorial plane; and an azido nitrogen in the axial position $(\tau=0.07)$; and a square planar geometry at $\mathrm{Cu}(2)(\tau=0.22)$ defined by phenoxide $\mathrm{O}$, imine $\mathrm{N}$, and two azido nitrogen atoms in the equatorial plane. ( $\tau$ is a geometric parameter which is applicable to five coordinate structures as an index of the degree of trigonality). The sum of the angles in the basal plane of $\mathrm{Cu}(1)$ and $\mathrm{Cu}(2)$ are $359.4(3)^{\circ}$ and $358.0(3)^{\circ}$ respectively, indicating planar arrangements around these metal centers allowing effective overlap of the atomic orbitals for effective spin-exchange interactions between the metal centers. In a dinuclear unit, the bridge angles at the phenoxide oxygen $(\mathrm{O}(1))$ and azido nitrogen $(\mathrm{N}(6))$ are $101.88^{\circ}$ and $102.4(3)^{\circ}$ respectively. The sum of the angles around the phenoxide bridging $\mathrm{O}$-atom, $\mathrm{O}(1)$, and an azide bridging $\mathrm{N}$-atom, $\mathrm{N}(6)$ are $360.0(4)^{\circ}$ and $356.8(5)^{\circ}$ respectively, indicating fairly planar arrangements at these atoms to allow effective magnetic exchange interactions between the $\mathrm{Cu}(1)$ and $\mathrm{Cu}(2)$ ions in the dinuclear unit. The sum of the angles at $\mathrm{N}(3)\left(355.0(5)^{\circ}\right)$, indicates some distortion from planarity. The bridge angle of $101.9(2)^{\circ}$ at phenoxy oxygen, $\mathrm{O}(1)$ and of $102.4(3)^{\circ}$ at the $\mu-1,1-\mathrm{N}_{3}$ nitrogen, $\mathrm{N}(6)$, suggests an antiferromagnetic and a ferromagnetic interaction between copper centers within the dinuclear units $[39,56]$.

\subsection{2. $\left[\mathrm{Cu}_{4}\left(\mathrm{~L}^{3-}\right)_{2}(\mathrm{OH})_{2}\left(\mathrm{H}_{2} \mathrm{O}\right)_{2}\right](2)$}

The molecular structure of centrosymmetric complex 2 is comprised of discreate neutral tetranuclear $\left[\mathrm{Cu}_{4}\left(\mathrm{~L}^{3-}\right)_{2}\left(\mu_{3}-\mathrm{OH}\right)_{2}\left(\mathrm{H}_{2} \mathrm{O}\right)_{2}\right]$ units, and is shown in Figure 4 , together with relevant atomic labeling. Important bond distances and angles are listed in Table S2. The coordination mode of $\mathrm{H}_{3} \mathrm{~L}$ in 2 is quite different from that in complex 1 . In $2, \mathrm{H}_{3} \mathrm{~L}$ utilizes its full coordination potential acting as a pentadentate $\left(\mathrm{N}_{2} \mathrm{O}_{3}\right)$ trianionic $\left(\mathrm{L}^{3-}\right)$ ligand by binding through two imine nitrogen, deprotonated phenoxy oxygen, and two deprotonated alkoxy oxygen atoms in the side arms. $\mathrm{L}^{3-}$ holds two Cu(II) ions in close proximity in a dinuclear unit bridged by two single atom bridges: a deprotonated phenoxy oxygen of the ligand, and a hydroxy bridge $\left(\mu_{3}-\mathrm{OH}^{-}\right)$. The two dinuclear units are linked through two $\mu_{3}-\mathrm{OH}^{-}$ions $(\mathrm{Cu}-\mathrm{O}=2.361 \AA)$, which in addition to providing an intra-dinuclear bridge also act as an inter-dinuclear bridge, forming neutral tetranuclear units.

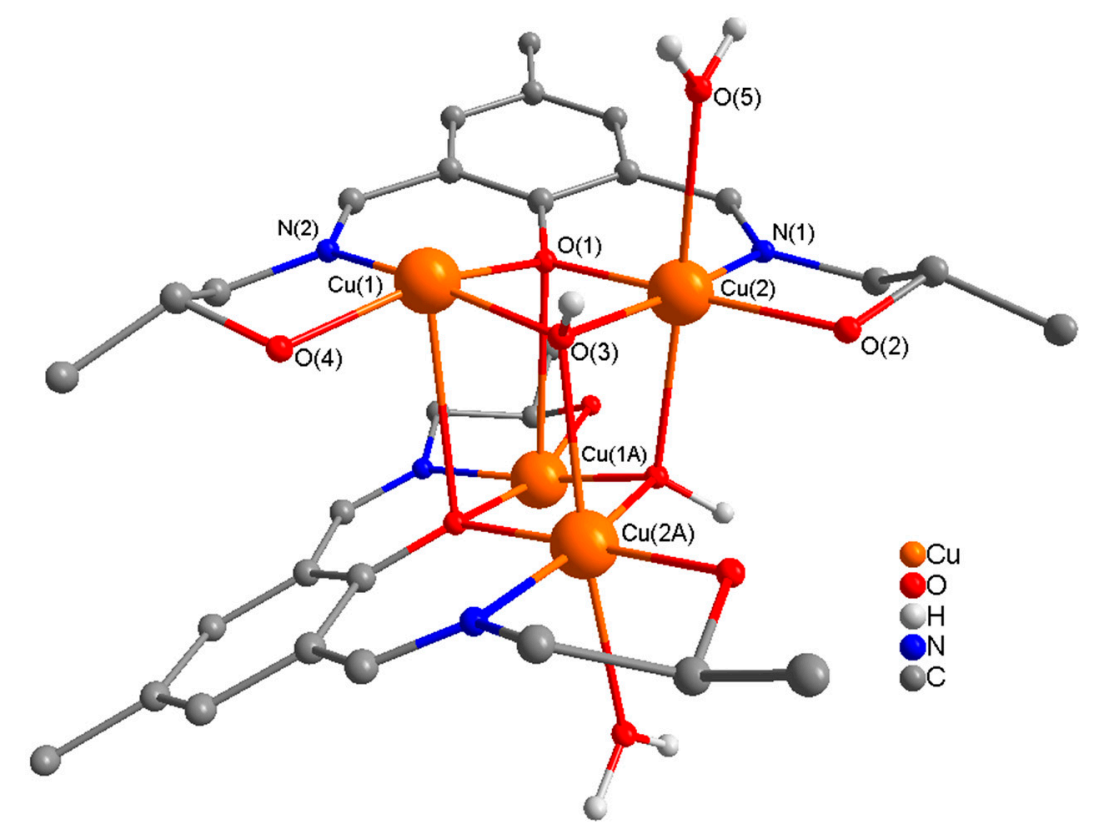

Figure 4. Molecular structure of the tetranuclear unit $\left[\mathrm{Cu}_{4}\left(\mathrm{~L}^{3-}\right)_{2}(\mathrm{OH})_{2}\left(\mathrm{H}_{2} \mathrm{O}\right)_{2}\right](2)$ with numbering of relevant atoms in the coordination environment. $\mathrm{H}$ atoms and solvent molecules are omitted for clarity. Atoms with A in their labels are symmetry generated.

The geometry at $\mathrm{Cu}(1)$ in the dinuclear unit can best be described as distorted square pyramidal with phenoxide $\mathrm{O}$, imine $\mathrm{N}$, alkoxide $\mathrm{O}$, and a $\mu_{3}$-hydroxy $\mathrm{O}$ atoms in the basal plane, and a phenoxy 
oxygen $\mathrm{O}(1 \mathrm{~A})$ in the axial plane $(\tau=0.21)$; a distorted octahedral geometry at $\mathrm{Cu}(2)$ defined by phenoxide $\mathrm{O}$, imine $\mathrm{N}$, alkoxide $\mathrm{O}$, and $\mu_{3}$-hydroxy $\mathrm{O}$ atoms in the equatorial plane and a $\mu_{3}$-hydroxy $\mathrm{OA}$ and a water $\mathrm{O}$ in the axial plane. The sum of the angles in the basal plane of $\mathrm{Cu}(1)$ and $\mathrm{Cu}(2)$ are $357.32(5)^{\circ}$ and $359.98(15)^{\circ}$ respectively, indicating almost planar arrangements around these metal centers. In a dinuclear unit the bridge angles at the phenoxide oxygen $(\mathrm{O}(1))$ and $\mu_{3}-\mathrm{OH}^{-}(\mathrm{O}(3))$ are $98.02(14)^{\circ}$ and $99.05(15)^{\circ}$ respectively which are significantly smaller than observed in 1 . The sum of the angles around the phenoxide bridging $\mathrm{O}$-atom, $\mathrm{O}(1)$ and $\mu_{3}-\mathrm{OH}^{-}$bridging $\mathrm{O}$-atom $(\mathrm{O}(3))$ are $351.82(7)^{\circ}$ and $301.19(14)^{\circ}$ respectively, indicating a significant distortion from planarity and a strong pyramidal distortion respectively.

\subsection{3. $\left[\mathrm{Cu}_{2}\left(\mathrm{H}_{3} \mathrm{~L}^{2-}\right)\left(\mathrm{N}_{3}\right)\left(\mathrm{H}_{2} \mathrm{O}\right)\left(\mathrm{NO}_{3}\right)\right](3)$}

$\mathrm{H}_{5} \mathrm{~L} 1$ is a potentially heptadentate penta-anionic double Schiff base ligand. Only one tetranuclear $\mathrm{Ni}^{2+}$ complex of this ligand has been reported [43]. In this publication, we are presenting the results of our investigation on the coordination versatility of this ligand towards copper(II) ions and the effect of the anions on the coordination ability of the ligand and the structural complexity. Reactions of copper(II) ions with $\mathrm{H}_{5} \mathrm{~L} 1$ under varied conditions produce complexes of diverse nuclearities including dinuclear (3), heptanuclear (5), decanuclear (6), and polynuclear (4). In the dinuclear compound (3), $\mathrm{H}_{3} \mathrm{~L}^{2-}$ acts a pentadentate $\left(\mathrm{N}_{2} \mathrm{O}_{3}\right)$ dianionic dinucleating ligand binding through phenoxide $\mathrm{O}$, two imine $\mathrm{N}$ atoms, and two alkoxide $\mathrm{O}$ atoms in the side arms of the ligand. The second ethanol $(-\mathrm{OH})$ group in the side arm of either side remains protonated and uncoordinated. On one side, oxygen atom $(\mathrm{O}(2 \mathrm{~A})$ \& $\mathrm{O}(2 \mathrm{~B}))$ of ethanol group in the side arm is present at two positions with half-occupancy. In 3, the copper centers are bridged by a phenoxide $\mathrm{O}(1) \mathrm{of}_{3} \mathrm{~L}^{2-}$ and an end-on (EO) azido, $\mu-1,1-\mathrm{N}_{3}$ bridge. The perspective view of 3 is shown in Figure 5. The dinuclear units grow into $2 \mathrm{D}$-sheets along the $a b$ or $a c$-axis (Figure S1), which are crosslinked along the $c$ or $b$-axis to generate a very fascinating supramolecular 3D-structure through a symmetrical, reasonably strong network of H-bonding interactions (2.511-3.000 ^) involving two uncoordinated protonated $(\mathrm{O}(2)$ and $\mathrm{O}(9))$, coordinated protonated $(\mathrm{O}(8))$, and coordinate deprotonated $(\mathrm{O}(3))$. ethanoate groups in the side arms of the ligand $\left(\mathrm{H}_{3} \mathrm{L1}^{2-}\right)$, coordinated water $(\mathrm{O}(4))$, coordinated azide ion $(\mathrm{N}(5))$, and coordinated nitrate ion $(\mathrm{O}(5), \mathrm{O}(6), \mathrm{O}(7))$ : $\mathrm{O}(2)-\mathrm{O}(5)=2.783 \AA, \mathrm{O}(4)-\mathrm{O}(6)=2.896 \AA, \mathrm{O}(9)-\mathrm{O}(7)=2.848 \AA$, $\mathrm{O}(3)-\mathrm{O}(4)=2.773 \AA, \mathrm{O}(3)-\mathrm{O}(8)=2.511 \AA$, and $\mathrm{O}(2)-\mathrm{N}(5)=3.00 \AA$. (see Figure 6).

The relevant bond distances and angles are listed in Table S3. The stereochemistry at each copper(II) ion can best be described as a distorted square pyramidal $(\tau(\mathrm{Cu}(1)=0.22$ and $\mathrm{Cu}(2)=0.13)$. The coordination geometry at each copper(II) ion in the basal plane consists of a phenoxide O-atom $(\mathrm{O}(1))$, an imine $\mathrm{N}$-atom, $(\mathrm{N}(1) / \mathrm{N}(2))$, an alkoxide $\mathrm{O}$-atom, $(\mathrm{O}(8) / \mathrm{O}(3))$, and an azido nitrogen atom $(\mathrm{N}(3))$, and a relatively longer contact with oxygen atom $(\mathrm{O}(5) / \mathrm{O}(4))$ of the nitrate/water at the axial position. The sum of the angles in the basal plane of $\mathrm{Cu}(1)$ and $\mathrm{Cu}(2)$ are $359.08(8)^{\circ}$ and $358.68(8)^{\circ}$ respectively, indicating planar arrangements at these metal centers. In a dinuclear unit of $\mathbf{3}$, the bridge angles at the phenoxide oxygen atom $(\mathrm{O}(1))$ and the azido nitrogen atom $(\mathrm{N}(3))$ are $100.80(8)^{\circ}$ and $100.07(9)^{\circ}$, respectively. The sum of the angles at the oxygen atom of the phenoxide bridge, $\mathrm{O}(1)$, and the nitrogen atom of the azido bridge, $\mathrm{N}(3)$, are $359.85(13)^{\circ}$ and $358.37(15)^{\circ}$ respectively, indicating planar arrangements around $\mathrm{O}(1)$ and $\mathrm{N}(3)$ for effective spin-exchange interactions between copper centers of the dinuclear core. The $\mathrm{Cu}(1)-\mathrm{Cu}(2)$ distance of $3.019 \AA$ in a dinuclear unit is intermediate between 1 (3.092 $\AA$ ) and 2 (2.967 $\AA$ ), and similar to the distance found in other dinuclear copper complexes with similar ligands [48,49,58-66]. 


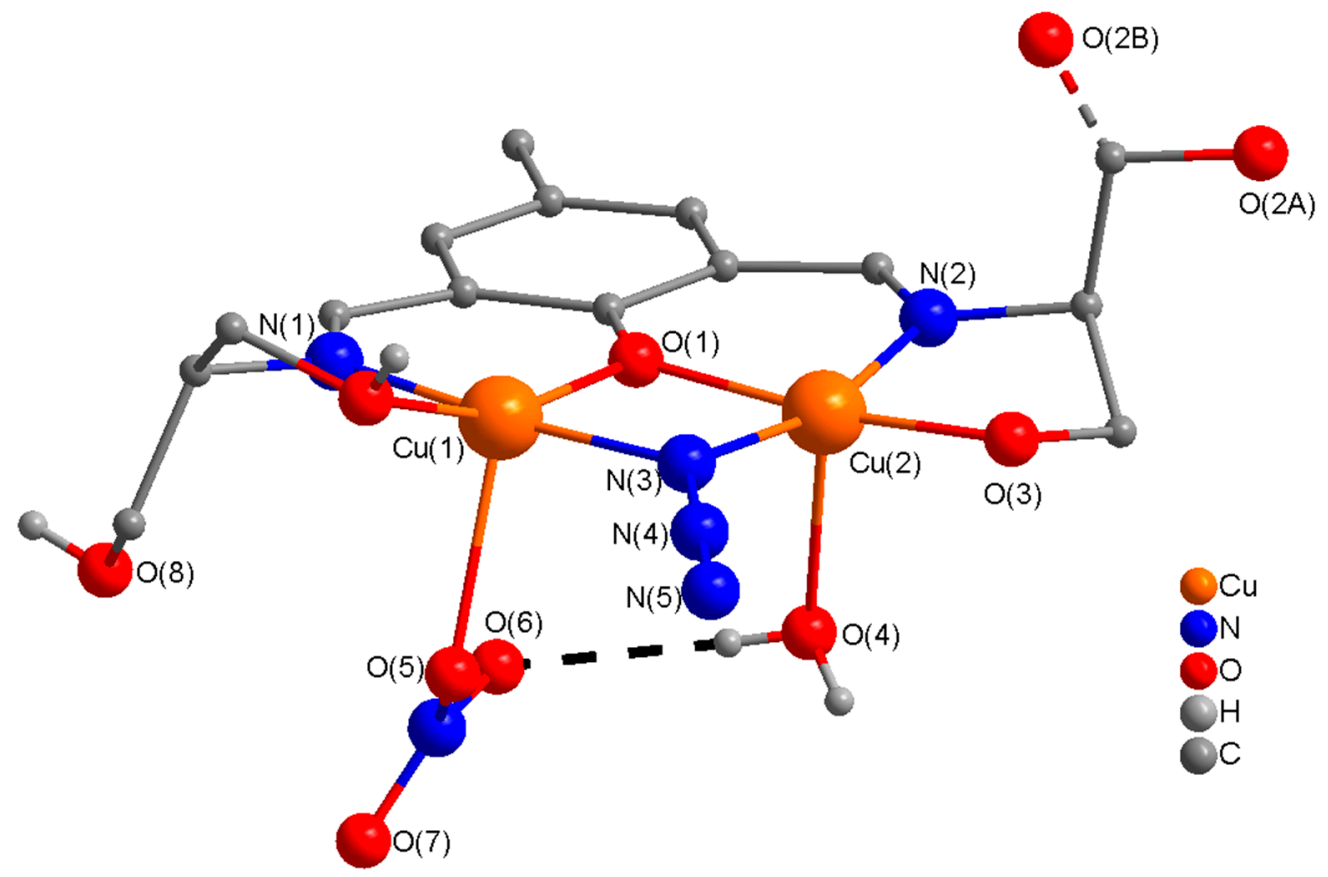

Figure 5. Molecular structure of a dinuclear unit $\left[\mathrm{Cu}_{2}\left(\mathrm{H}_{3} \mathrm{L1}^{2-}\right)\left(\mathrm{H}_{2} \mathrm{O}\right)\left(\mathrm{NO}_{3}\right)\left(\mathrm{N}_{3}\right)\right]$ (3) with relevant numbering. H-atoms are omitted for clarity.

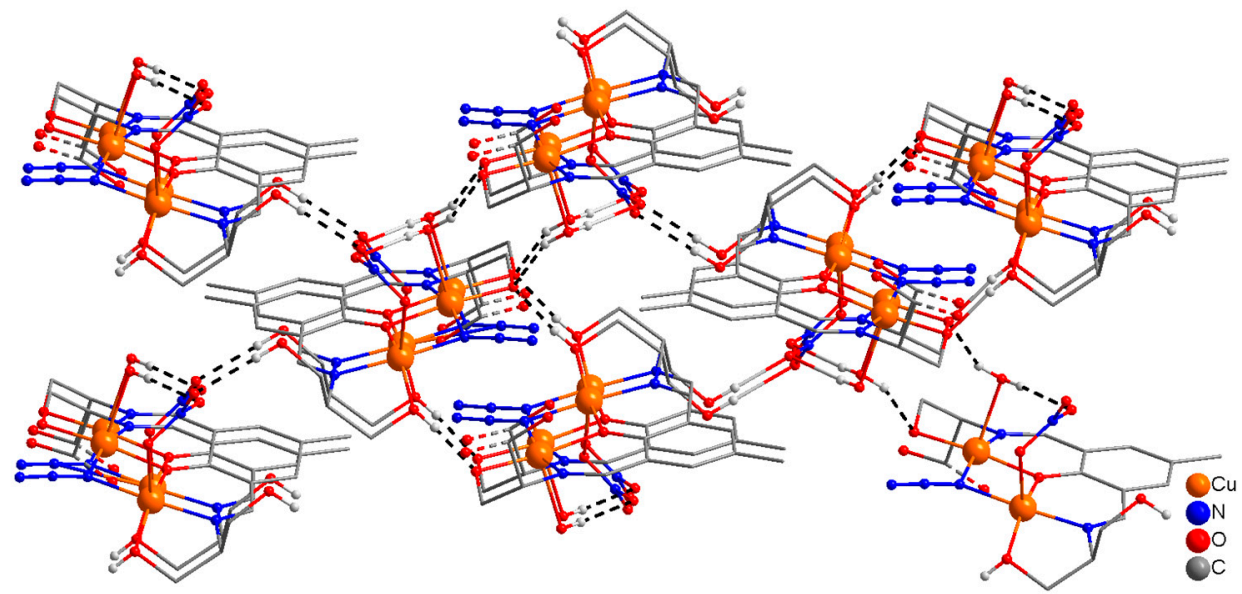

Figure 6. Perspective view of 3D-structure of 3.

\subsection{4. $\left\{\left[\mathrm{Cu}_{2}\left(\mathrm{H}_{3} \mathrm{~L}^{2-}\right)\left(\mathrm{H}_{2} \mathrm{O}\right)\left(\mathrm{BF}_{4}\right)\left(\mathrm{N}_{3}\right)\right] \cdot \mathrm{H}_{2} \mathrm{O}\right\}_{\mathrm{n}}(4)$}

The molecular structure of a dinuclear unit in complex 4 is shown in Figure 7, together with relevant atomic labeling. Important bond distances and angles are listed in Table S4. The structure of compound 4 consists of polymeric one-dimensional single chains along the $b$ axis, in which dinuclear $\left[\mathrm{Cu}_{2}\right]$ units are linked via an oxygen atom $(\mathrm{O}(5))$ of the ethanoate $\mathrm{OH}$ in the side arm of the ligand (Figure S2). These chains are cross linked via a strong network of intramolecular/intermolecular H-bonds $[\mathrm{O}(5)-\mathrm{O}(6)=2.739 \AA, \mathrm{O}(4)-\mathrm{O}(7)=2.885 \AA, \mathrm{O}(6)-\mathrm{O}(7)=2.788 \AA, \mathrm{O}(6)-\mathrm{O}(7 \mathrm{~A})=2.737 \AA]$ involving the coordinated $(\mathrm{O}(4),(\mathrm{O} 5))$ hydroxyl groups of ethanol in the side arms of the ligand and the coordinated $(\mathrm{O}(6)) /$ uncoordinated $(\mathrm{O}(7))$ water molecules generating $2 \mathrm{D}$ sheets along $b c$ axis which are further cross linked to produce an interesting 3D supramolecular structure (Figure 8). In complex 4, the coordination mode of $\mathrm{H}_{5} \mathrm{~L} 1$ is identical to that present in $3 . \mathrm{H}_{5} \mathrm{~L} 1$ acts as pentadentate $\left(\mathrm{N}_{2} \mathrm{O}_{3}\right)$ dianionic ligand $\left(\mathrm{H}_{3} \mathrm{~L}^{2-}\right)$, coordinating via two imine nitrogen atoms, a deprotonated phenoxide oxygen, a deprotonated alkoxide oxygen, and a protonated ethanolic $\mathrm{OH}$ group in the side arm of 
the ligand thereby bridging two copper(II) ions into dinuclear units. The second alkoxy group on either side of the Schiff-base ligand remains protonated and uncoordinated. As in compounds $\mathbf{1}$ and $\mathbf{3}$, the two $\mathrm{Cu}(\mathrm{II})$ ions in each dinuclear unit are bridged via a phenoxide oxygen and a $\mu-1,1-\mathrm{N}_{3}$ bridge.

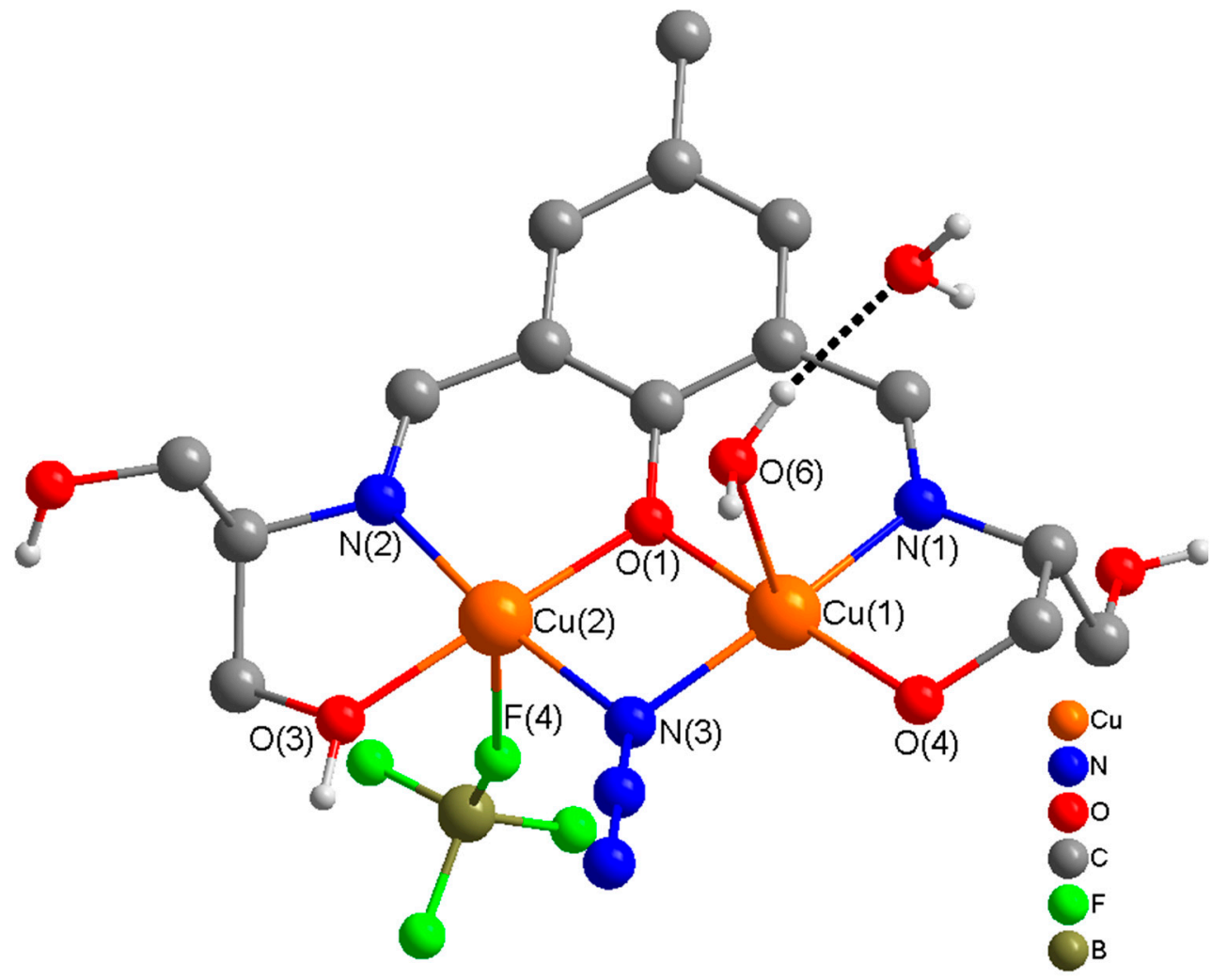

Figure 7. Molecular structure of a dinuclear unit $\left[\mathrm{Cu}_{2}\left(\mathrm{H}_{3} \mathrm{~L}^{2-}\right)\left(\mathrm{H}_{2} \mathrm{O}\right)\left(\mathrm{BF}_{4}\right)\left(\mathrm{N}_{3}\right)\right] \cdot \mathrm{H}_{2} \mathrm{O}$ in (4) with numbering of relevant atoms in the coordination environment. H-atoms are omitted for clarity.

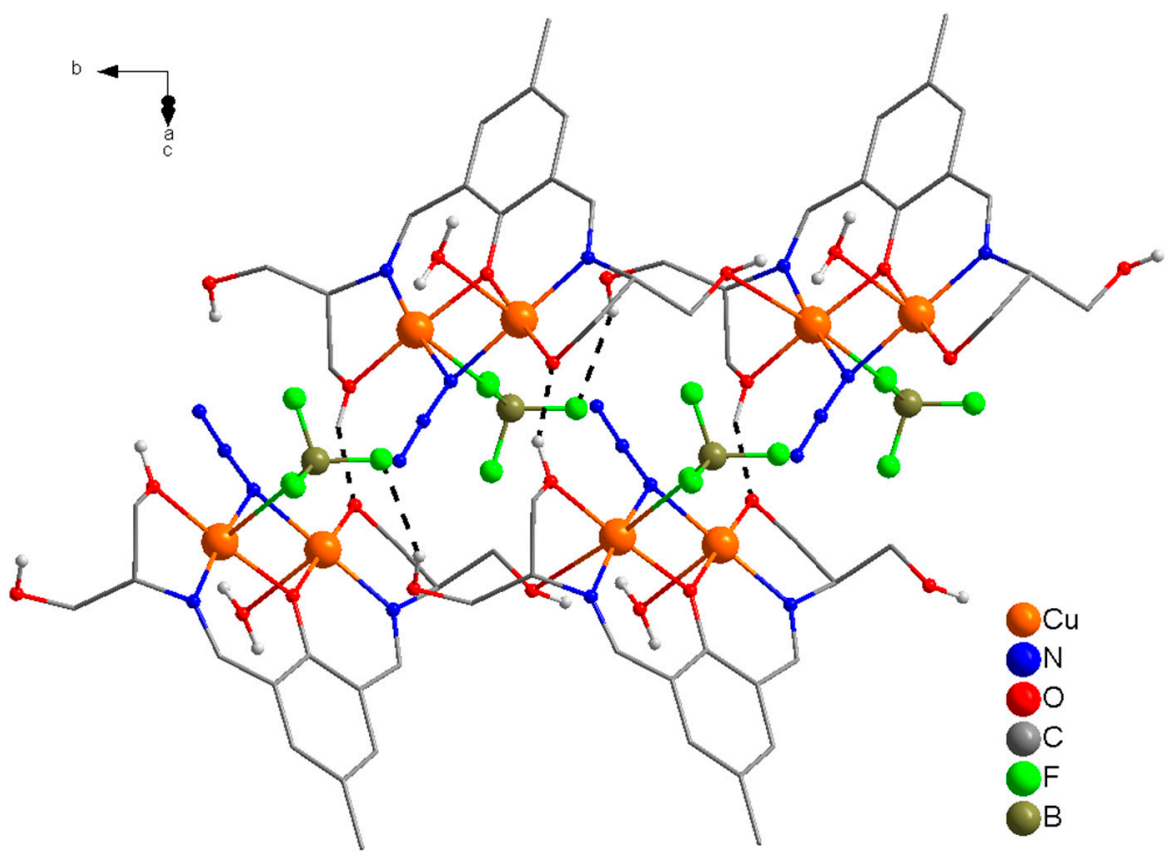

Figure 8. Perspective view of a portion of 3D supramolecular structure of 4 . 
The stereo-chemical environment at $\mathrm{Cu}(1)$ and $\mathrm{Cu}(2)$ can best be described as distorted square pyramidal $(\tau=0.12)$, and distorted octahedral respectively. The coordination geometry in the basal plane of each copper(II) ion is defined by a phenoxide O-atom, $(\mathrm{O}(1))$, an imine $\mathrm{N}$-atom, $(\mathrm{N}(1) / \mathrm{N}(2))$, an alkoxide O-atom, $(\mathrm{O}(4) / \mathrm{O}(3))$, and azido nitrogen atoms $(\mathrm{N}(3))$, with oxygen atom $(\mathrm{O}(5) / \mathrm{O}(6))$ of the ethanol $\mathrm{OH}$ group in the side arm of the Schiff base ligand/water at the axial position. There is a weak axial contact of $\mathrm{Cu}(2)$ with $\mathrm{F}(4)$ of $\mathrm{BF}_{4}{ }^{-}$, thus giving a distorted octahedral geometry at $\mathrm{Cu}(2)$. The sum of the angles in the basal plane of $\mathrm{Cu}(1)$ and $\mathrm{Cu}(2)$ are $359.97(18)^{\circ}$ and $360.24(18)^{\circ}$, respectively, indicating planar arrangements at these metal centers for effective magnetic interaction.

In dinuclear units of 4, the bridge angles at the phenoxide oxygen atom $(\mathrm{O}(1))$ and the azido nitrogen atom $(\mathrm{N}(3))$ are $100.44(17)^{\circ}$ and $97.8(2)^{\circ}$, respectively. The sum of the angles at the oxygen atom of the phenoxide bridge, $\mathrm{O}(1)$, and the nitrogen atom of the azido bridge, $\mathrm{N}(3)$ are $358.54(8)^{\circ}$ and 353.(3) ${ }^{\circ}$, respectively, indicating planar arrangements around $\mathrm{O}(1)$ and a slight distortion at $\mathrm{N}(3)$.

\subsection{5. $\left[\mathrm{Cu}_{7}\left(\mathrm{H}_{3} \mathrm{L1}^{2-}\right)_{2}(\mathrm{O})_{2}\left(\mathrm{C}_{6} \mathrm{H}_{5} \mathrm{CO}_{2}\right)_{6}\right] \cdot 6 \mathrm{CH}_{3} \mathrm{OH} \cdot 44 \mathrm{H}_{2} \mathrm{O}(5)$}

There are fewer examples of heptanuclear copper(II) complexes in the literature in comparison with other nuclearities [23,109-113]. In complex 5, two dinuclear $\left[\mathrm{Cu}_{2} \mathrm{H}_{3} \mathrm{~L}^{2-}\right]$ units are connected to three copper(II) ions which are bonded to benzoate ions in a heptanuclear associated arrangement. In this complex, the benzoate ions exhibit four different types of bridging modes including $\left(\mu_{4}-1,1,3,3-\mathrm{C}_{6} \mathrm{H}_{5} \mathrm{CO}_{2}\right),\left(\mu_{3}-1,1,3-\mathrm{C}_{6} \mathrm{H}_{5} \mathrm{CO}_{2}\right),\left(\mu-1,3-\mathrm{C}_{6} \mathrm{H}_{5} \mathrm{CO}_{2}\right)$, and $\left(\mu-1,1-\mathrm{C}_{6} \mathrm{H}_{5} \mathrm{CO}_{2}\right)$, which is unprecedented. In our opinion, this constitutes the first report of a copper(II) complex in which benzoate ions exhibit four different types of bridging modes. In complex $5, \mathrm{H}_{5} \mathrm{~L} 1$ acts as hexadentate $\left(\mathrm{N}_{2} \mathrm{O}_{4}\right)$ dianionic ligand $\left(\mathrm{H}_{3} \mathrm{~L}^{2-}\right)$ binding through two imine nitrogen atoms, a deprotonated phenoxide oxygen, and a deprotonated alkoxide oxygen, and two protonated ethanol $(\mathrm{OH})$ groups in the side arms of the double Schiff base ligand, bridging two copper(II) ions into a dinuclear unit which is different from that in complexes 3 and 4 (pentadentate $\left(\mathrm{N}_{2} \mathrm{O}_{3}\right)$ ). One alkoxy group in one side arm of the Schiff-base ligand remains protonated and uncoordinated. In each dinuclear unit, two copper(II) ions are bridged through a phenoxide oxygen and $\mu_{3}-\mathrm{O}^{2-}$ bridges. Two dinuclear $\left[\mathrm{Cu}_{2}\right]$ units are connected to three $\mathrm{Cu}^{2+}$ ions which are held in place by $\mu_{3}-\mathrm{O}^{2-}$, alkoxide $\mathrm{O}$ in the side arm of the ligand, and bridging benzoate ions that produce an interesting heptacopper structure. A perspective view of the 5 is presented in Figure 9. Important distances and angles are listed in Table S5.

The stereochemistry at $\mathrm{Cu}(1) / \mathrm{Cu}(7)$ ion in each dinuclear unit can best be described as a distorted square pyramidal $(\tau(\mathrm{Cu}(1)=0.10$ and $\mathrm{Cu}(7)=0.04)$ with phenoxide $\mathrm{O}$, imine $\mathrm{N}$, alkoxide $\mathrm{O}$, and an oxide $\mathrm{O}\left(\mu_{3}-\mathrm{O}^{2-}\right)$ in the equatorial plane and a benzoate $\mathrm{O}$ in the axial plane. The stereochemistry at $\mathrm{Cu}(2) / \mathrm{Cu}(6)$ ion in each dinuclear can best be described as a distorted octahedral with phenoxide $\mathrm{O}$, imine $\mathrm{N}$, alkoxide $\mathrm{O}$, and an oxide $\mathrm{O}\left(\mu_{3}-\mathrm{O}^{2-}\right)$ in the equatorial plane and benzoate $\mathrm{O}$ atoms in the axial plane. The stereochemistry at the other three copper centers, $[\mathrm{Cu}(3),(\mathrm{Cu}(4)$, and $\mathrm{Cu}(5)]$ is also distorted octahedral. The sum of the angles in the basal plane of $\mathrm{Cu}(1), \mathrm{Cu}(2), \mathrm{Cu}(6)$, and $\mathrm{Cu}(7)$ are 359.7(2) ${ }^{\circ}$, $360.5(3)^{\circ}, 360,6(2)^{\circ}$, and $356.6(2)^{\circ}$ respectively, indicating almost planar arrangements around these metal centers. The sum of the angles at $\mathrm{Cu}(3), \mathrm{Cu}(4)$, and $\mathrm{Cu}(5)$ which are held together by benzoate bridges are $358.4(2)^{\circ}, 361.7(2)^{\circ}$, and $360,9(2)^{\circ}$ respectively, indicating planar arrangements around these metal centers. In the dinuclear units, the bridge angles at the phenoxide oxygen $(\mathrm{O}(1) / \mathrm{O}(17))$ and $\mu_{3}-\mathrm{O}^{2-}$ oxygen $(\mathrm{O}(6) / \mathrm{O}(22))$ are $99.7(2)^{\circ}$ and $96.9(2)^{\circ} / 98.0(2)^{\circ}$, respectively. The sum of the angles around the phenoxide bridging $\mathrm{O}$-atom, $\mathrm{O}(1) / \mathrm{O}(17)$, and triply bridging $\mu_{3}-\mathrm{O}^{2-} \mathrm{O}$-atoms, $(\mathrm{O}(6) / \mathrm{O}(22))$ are $359.3(4)^{\circ} / 359.8(4)^{\circ}$ and $315.8(2)^{\circ} / 317.4(2)^{\circ}$ respectively, indicating planar arrangements at the phenoxide oxygen and a distorted pyramidal arrangement at the oxide oxygen atoms to allow effective magnetic exchange interaction between the $\mathrm{Cu}(1) / \mathrm{Cu}(2)$ and $\mathrm{Cu}(6) / \mathrm{Cu}(7)$ ions in the dinuclear units. 


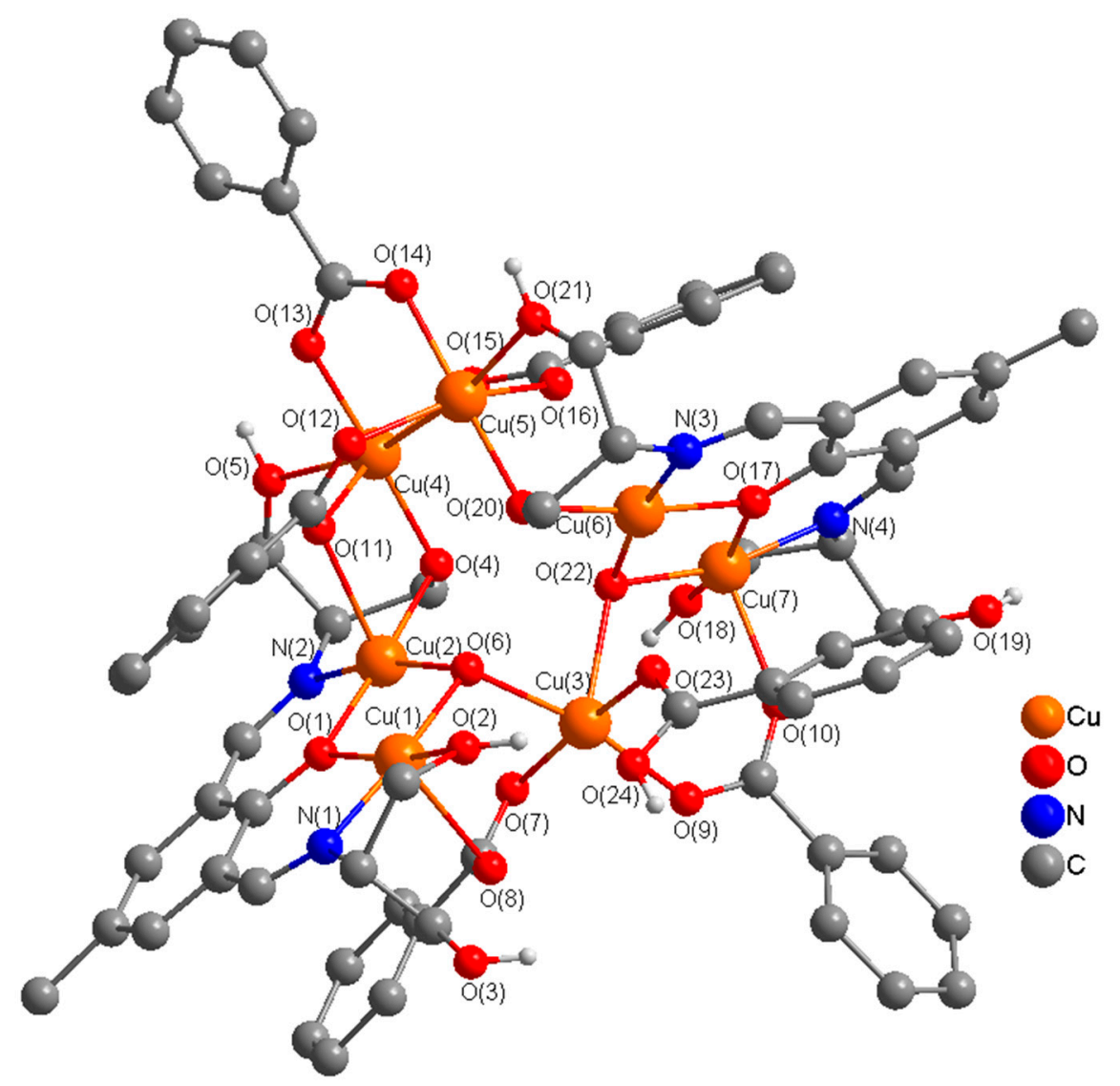

Figure 9. Perspective view of a heptanuclear complex $\left[\mathrm{Cu}_{7}\left(\mathrm{H}_{3} \mathrm{~L}^{2-}\right)_{2}(\mathrm{O})_{2}\left(\mathrm{C}_{6} \mathrm{H}_{5} \mathrm{CO}_{2}\right)_{6}\right]$ (5) with relevant numbering. H-atoms and solvent molecules are omitted for clarity.

\subsection{6. $\left[\mathrm{Cu}_{10}\left(\mathrm{H}_{3} \mathrm{L1}^{2-}\right)_{4}(\mathrm{O})_{2}(\mathrm{OH})_{2}\left(\mathrm{C}_{6} \mathrm{H}_{5} \mathrm{CO}_{2}\right)_{4}\right]\left(\mathrm{C}_{6} \mathrm{H}_{5} \mathrm{CO}_{2}\right)_{2} \cdot 20 \mathrm{H}_{2} \mathrm{O}(6)$}

In complex 6, two cationic dinuclear $\left[\mathrm{Cu}_{2} \mathrm{H}_{3} \mathrm{L1}^{2-}(\mathrm{OH})\right]^{+}$units are linked to two cationic trinuclear units $\left[\mathrm{Cu}_{3} \mathrm{H}_{3} \mathrm{~L}^{2-}\left(\mathrm{O}^{2-}\right)\left(\mathrm{C}_{6} \mathrm{H}_{5} \mathrm{CO}_{2}^{-}\right)\right]^{+}$via two alkoxide $\left(\mu-\mathrm{O}-\mathrm{R}^{-}\right)$ions in the side arms of the ligand and two triply bridging, $\mu_{3}-1,1,3-\mathrm{C}_{6} \mathrm{H}_{5} \mathrm{CO}_{2}{ }^{-}$ions to generate a centrosymmetric decanuclear complex 6 . In 6, four benzoate ions $\left(\mu_{3}-1,1,3-\mathrm{C}_{6} \mathrm{H}_{5} \mathrm{CO}_{2}{ }^{-}\right)$act as intra-dimer and inter-dimer bridges, generating a decacopper complex. In complex $6, \mathrm{H}_{5} \mathrm{~L} 1$ acts as pentadentate $\left(\mathrm{N}_{2} \mathrm{O}_{3}\right)$ dianionic ligand $\left(\mathrm{H}_{3} \mathrm{~L}^{2-}\right)$ as in 3 and $\mathbf{4}$, binding through two imine nitrogen atoms, a deprotonated phenoxide oxygen, and a deprotonated alkoxide oxygen, and a protonated ethanol $(\mathrm{OH})$ group in the side arm of the double Schiff base ligand. This is different from that in 5 , where $\mathrm{H}_{5} \mathrm{~L} 1$ acts as a hexadentate $\left(\mathrm{N}_{2} \mathrm{O}_{4}\right)$ dianionic ligand. Here one ethanol group $(\mathrm{OH})$ in the side arm of the ligand is deprotonated and acts as a bridge between dinuclear and trinuclear units to produce a decanuclear complex. One ethanol group $(\mathrm{OH})$ of the side arm remains protonated and coordinates to the $\mathrm{Cu}(\mathrm{II})$ ion in a dinuclear unit. Two ethanol groups of the side arms of the ligand remain protonated and uncoordinated. Two copper(II) ions in a dinuclear unit are bridged by a phenoxy oxygen and a hydroxy oxygen $\left(\mu-\mathrm{OH}^{-}\right)$, whereas two $\mathrm{Cu}$ (II) ions in another dinuclear unit are bridged by a phenoxide oxygen and a $\mu_{3}-\mathrm{O}^{2-}$ ion, which acts as an intradinuclear bridge as well as a link between a dinuclear unit and a trinuclear unit forming the decanuclear supramolecular architecture 6. A perspective view of the 6 is presented in Figure 10 and important distances and angles are listed in Table S6. 


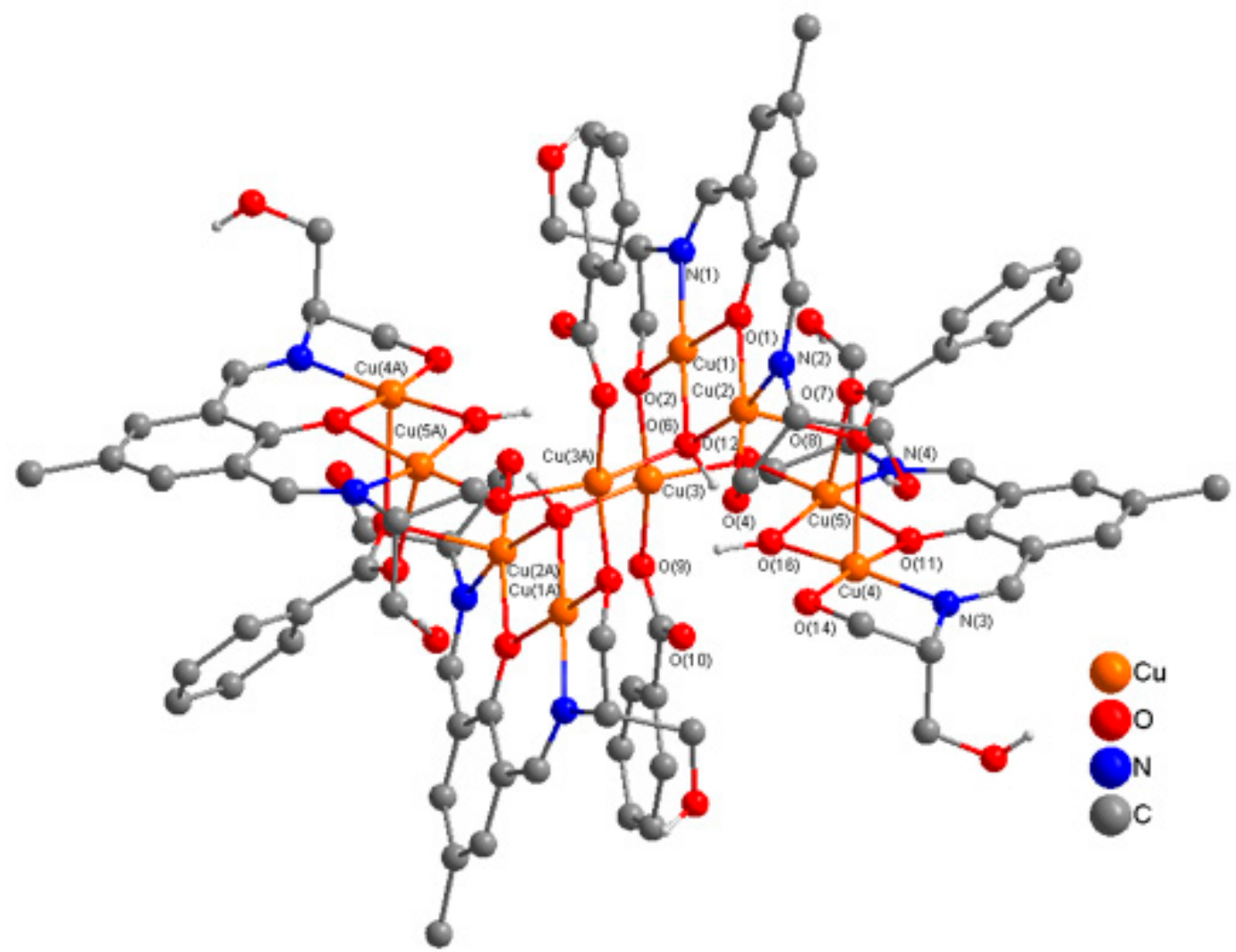

Figure 10. Perspective view of a cationic unit $\left[\mathrm{Cu}_{10}\left(\mathrm{H}_{3} \mathrm{L1}^{2-}\right)_{4}(\mathrm{O})_{2}(\mathrm{OH})_{2}\left(\mathrm{C}_{6} \mathrm{H}_{5} \mathrm{CO}_{2}\right)_{4}\right]^{2+}$ in decanuclear complex 6 with relevant numbering. $\mathrm{H}$-atoms, solvent molecules and uncoordinated $\left[\mathrm{C}_{6} \mathrm{H}_{5} \mathrm{CO}_{2}{ }^{-}\right]_{2}$ anions are omitted for clarity.

H-bonding forces, which are so important for stabilizing the structure of proteins and other biomolecules in living systems, play a prominent role in the stability of $\mathbf{6}$ and in the formation of 1D-single chains. There are remarkably strong intramolecular H-Bonding interactions $[\mathrm{O}(4)-\mathrm{O}(14)$ $=2.477 \AA, \mathrm{O}(6)-\mathrm{O}(16)=2.623 \AA, \mathrm{O}(10)-(\mathrm{O}(16)=2.787 \AA]$ between $\mu-\mathrm{OH}(\mathrm{O}(16)), \mu_{3}-\mathrm{O}^{2}(\mathrm{O}(6))$, $\mu_{3}-1,1,3-\mathrm{C}_{6} \mathrm{H}_{5} \mathrm{CO}_{2}{ }^{-}(\mathrm{O}(10))$, and $\mathrm{OH}(\mathrm{O}(4)$ and $\mathrm{O}(14))$ in the side arms of the ligand, which stabilize the structure. Complex 6 grows along the $a$-axis, generating an unprecedented supramolecular 1D-single chain through a network of $\mathrm{H}$-bonds $[\mathrm{O}(3)-\mathrm{O}(5)=2.797 \AA$ and $\mathrm{O}(13)-\mathrm{O}(15)=2.759 \AA$ ) between four protonated uncoordinated $\mathrm{OH}$ groups $(\mathrm{O}(3), \mathrm{O}(5), \mathrm{O}(13), \mathrm{O}(15))$ in the side chains of the ligands (see Figure 11).

The stereochemistry at $\mathrm{Cu}(1), \mathrm{Cu}(4)$, and $\mathrm{Cu}(5)$ can best be described as square pyramidal $(\tau(\mathrm{Cu}(1)=0.04, \mathrm{Cu}(4)=0.10$, and $\mathrm{Cu}(5)=0.06)$ with phenoxide $\mathrm{O}$, imine $\mathrm{N}$, alkoxide $\mathrm{O}$, and an oxide $\mathrm{O}\left(\mu_{3}-\mathrm{O}^{2-}\right) /$ hydroxy $(\mu-\mathrm{OH})$ in the equatorial plane and a benzoate $\mathrm{O}$ in the axial plane. The stereochemistry at the $\mathrm{Cu}(3)$ ion can best be described as a distorted square planar $(\tau=0.05)$ with one benzoate $\mathrm{O}$, two alkoxide $\mathrm{O}$, and one hydroxide $\mathrm{O}\left(\mu-\mathrm{OH}^{-}\right)$in the equatorial plane. The geometry at $\mathrm{Cu}(2)$ is distorted octahedral with phenoxide $\mathrm{O}$, imine $\mathrm{N}$, alkoxide $\mathrm{O}$, and an oxide $\mathrm{O}\left(\mu_{3}-\mathrm{O}^{2-}\right)$ in the equatorial plane and benzoate $\mathrm{O}$ atoms in the axial plane. The sum of the angles in the basal plane of $\mathrm{Cu}(1)$ to $\mathrm{Cu}(5)$ are $360.2(4)^{\circ}, 358.3(3)^{\circ}, 364,1(3)^{\circ}, 359.5(4)^{\circ}$ and $358.7(4)^{\circ}$ respectively, indicating almost planar arrangements around these metal centers. In the dinuclear units, the bridge angles at the phenoxide oxygen $(\mathrm{O}(1) / \mathrm{O}(11))$ are $97.5(4)^{\circ} / 97.3(4)^{\circ}$, similar to 5 . The $\mathrm{Cu}(4)-\mathrm{O}(16)-\mathrm{Cu}(5)$ bridge angle at doubly bridged hydroxide $(\mu-\mathrm{OH}) \mathrm{O}$ is $97.3(4)^{\circ}$ and $\mathrm{Cu}(1)-\mathrm{O}(6)-\mathrm{Cu}(2), \mathrm{Cu}(2)-\mathrm{O}(6)-\mathrm{Cu}(3 \mathrm{~A}), \mathrm{Cu}(1)-\mathrm{O}(6)-\mathrm{Cu}(3 \mathrm{~A})$ bridge angles at the triply bridged oxide $\left(\mu_{3}-\mathrm{O}^{2-}\right) \mathrm{O}$ are $97.1(4)^{\circ}, 102.0(5)^{\circ}$, and $118.9(4)^{\circ}$ respectively. The sum of the angles around the phenoxide bridging $\mathrm{O}$-atoms, $\mathrm{O}(1)$ and $\mathrm{O}(11)$ are $359.1(8)^{\circ}$ and $353.3(8)^{\circ}$ respectively, indicating planar and a distorted planar arrangements at these atoms. The sum of the 
angles at alkoxide $\mathrm{O}$-atoms, $\mathrm{O}(2)$ and $\mathrm{O}(12)$ are $345.9(7)^{\circ}$ and $346.9(7)^{\circ}$ indicating a distorted pyramidal arrangement at oxide oxygen atoms.

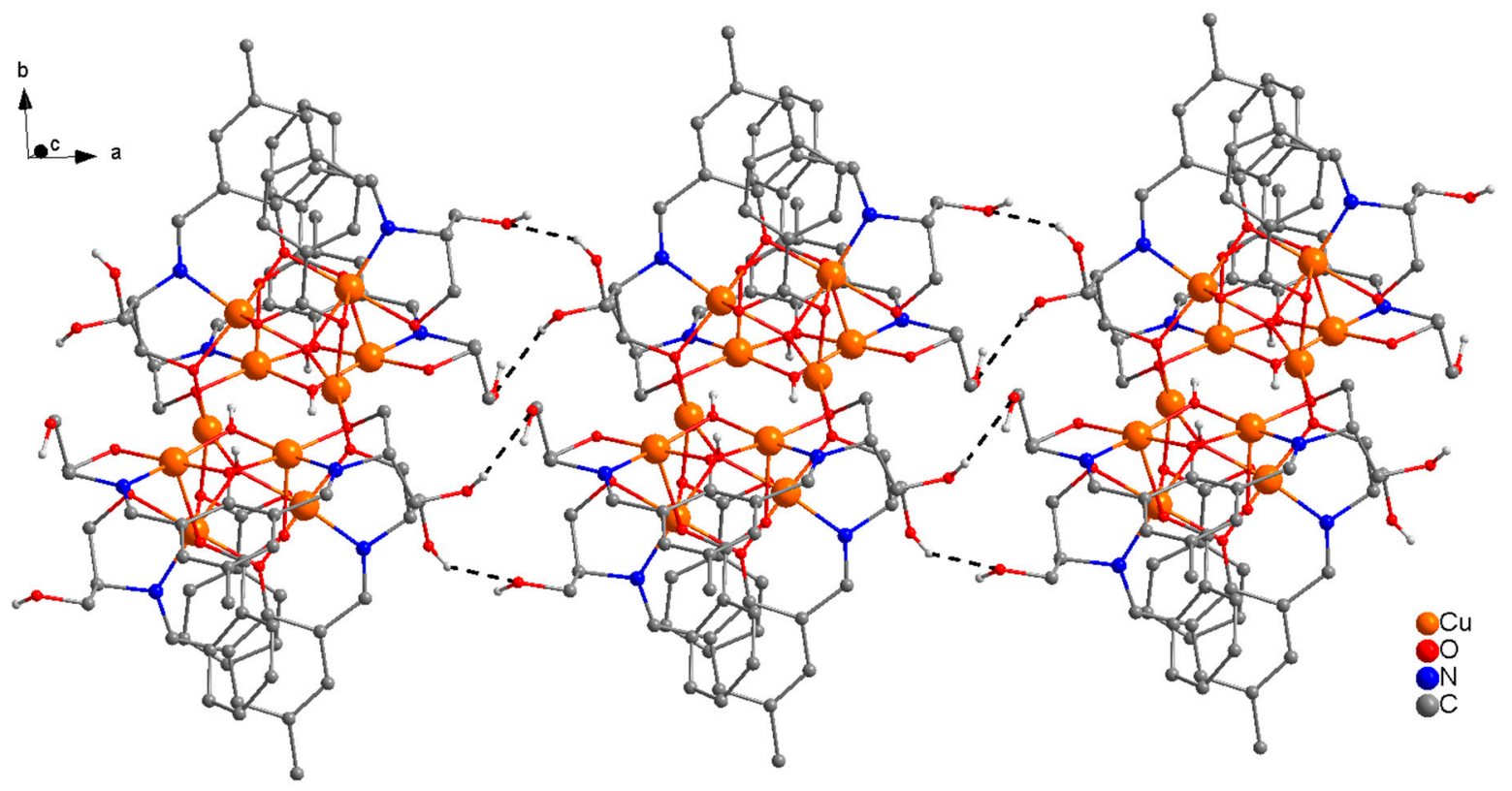

Figure 11. Perspective view of a portion of 1D-single chain along $a$-axis in the structure of 6 .

\subsection{Magnetic Properties}

In the compounds under investigation, the $\mathrm{Cu}-\mathrm{Cu}$ distances are quite short. The copper ions in the dinuclear units are bridged via single atom-phenoxy oxygen atom of the ligand and end-on azido $\mu-1,1-\mathrm{N}_{3} /$ hydroxy $\left(\mu-\mathrm{OH}^{-}\right)$/oxide $\left(\mu-\mathrm{O}^{2-}\right)$ bridges and are likely to result in magnetic exchange interactions between closely placed metal centers. Variable temperature magnetic studies have been carried out on 1, 3, and 5, and the results of our investigations are presented as the best fit curves along with experimental data in the Figures 12-14 respectively. Based on the structural information, we anticipate the presence of strong antiferromagnetic spin exchange interactions via the $\mathrm{PhO}^{-}$and $\mathrm{N}_{3}{ }^{-}$/hydroxy $\left(\mu-\mathrm{OH}^{-}\right)$/oxide $\left(\mu-\mathrm{O}^{2-}\right)$ bridges within the $\left[\mathrm{Cu}_{2}\right]$ units in these complexes, which involve all equatorial positions of the metals and bridging units.

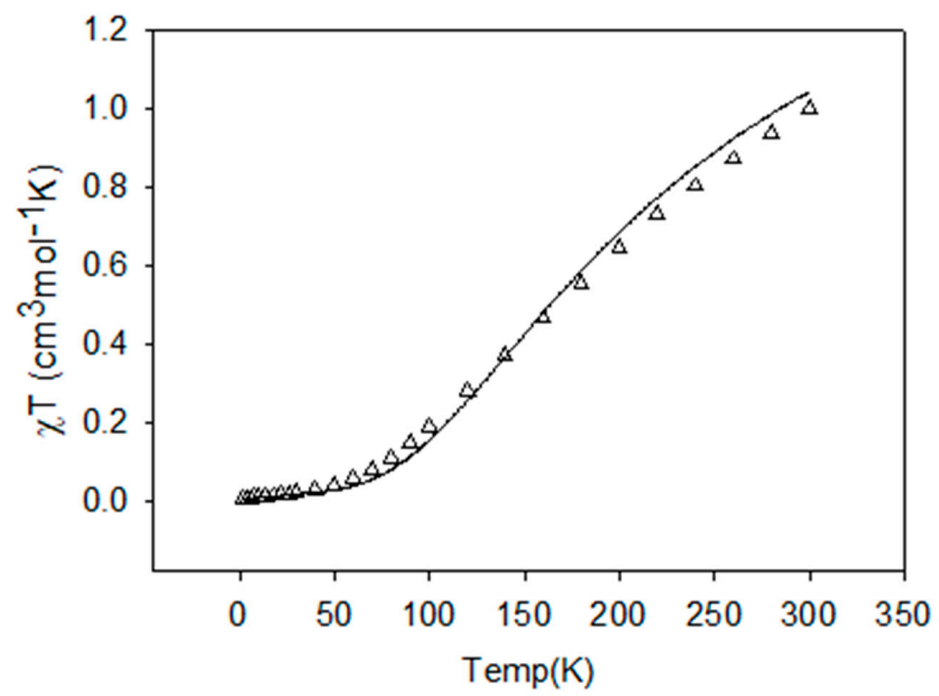

Figure 12. Plots of $\chi_{M} T$ (triangles) vs. $T$ per mole of $\left[\mathrm{Cu}_{2}\right]$ unit for $\mathbf{1}$. The solid line is the best fit to the experimental data. 


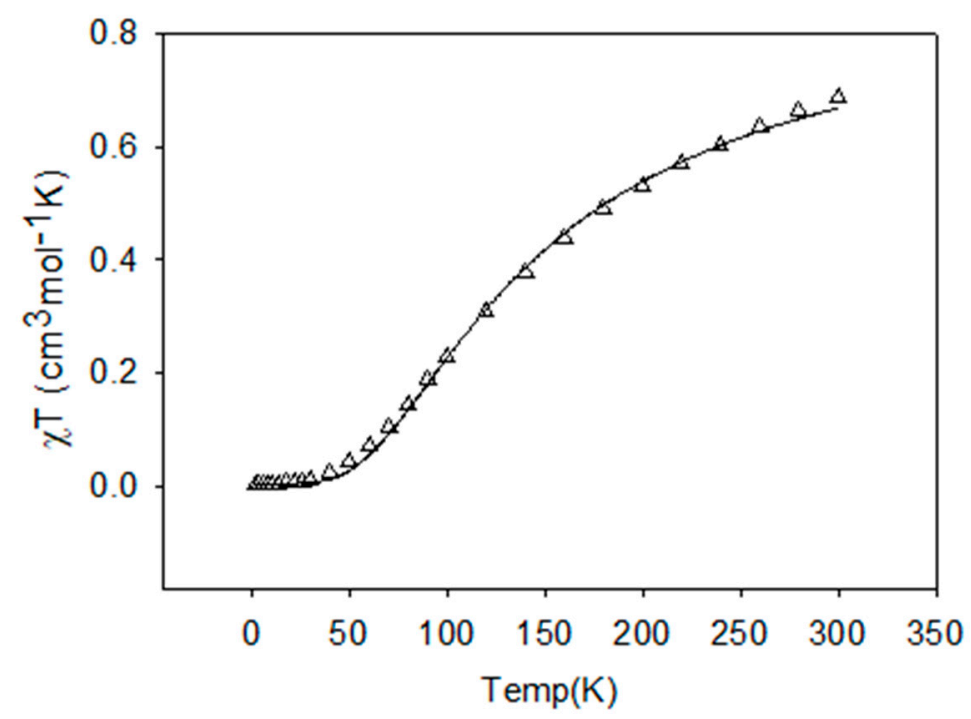

Figure 13. Plots of $\chi_{M} T$ (triangles) vs. $T$ per mole of $\left[\mathrm{Cu}_{2}\right]$ unit for 3 . The solid line is the best fit to the experimental data.

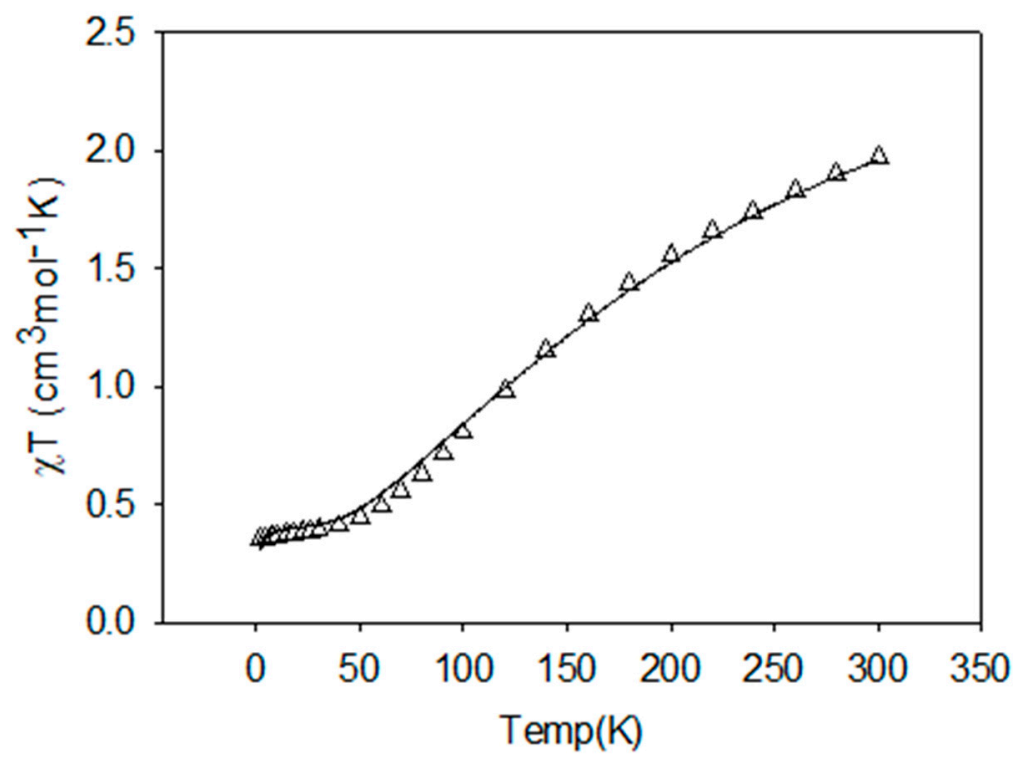

Figure 14. Plots of $\chi_{M} T$ (triangles) vs. $T$ per mole of $\left[\mathrm{Cu}_{2}\right]$ unit for 5 . The solid line is the best fit to the experimental data.

Despite the butterfly, cubane type structure of complex 1, the basic arrangement is comprised of two almost planar dinuclear fragments joined axially through long (2.4 $⿱$ ) and a very long $(3.02 \AA)$ axial contacts. Theoretically, these axial contacts are orthogonal and so contribute little to overall antiferromagnetic exchange [114]. Looking at the $\mathrm{Cu}-\mathrm{O}-\mathrm{Cu}$ and $\mathrm{Cu}-\mathrm{N}-\mathrm{Cu}$ angles, one would expect net antiferromagnetic (AF) exchange, as is observed experimentally. The best fit to a dinuclear model is not brilliant, and gives $\mathrm{g}=2.03, \mathrm{~J}=-278 \mathrm{~cm}^{-1}$, temperature independent magnetism (TIP) $=445 \times 10^{-6} \mathrm{~cm}^{3} \mathrm{~mol}^{-1}$, and fraction paramagnetic impurity $(\rho)=0.003,10^{2} R=9.38$. (R represents the agreement factor of data fitting which can be defined as $\left.\mathrm{R}=\sum\left[\left(\chi_{M} \mathrm{~T}\right)_{\exp }-\left(\chi_{M} \mathrm{~T}\right)_{\text {calc }}\right]^{2} / \sum\left[\left(\chi_{M} T\right)_{\exp }\right]^{2}\right)$. This was the best fit possible, based on the projected exchange model.

$$
\mathrm{H}_{\mathrm{ex}}=-\mathrm{J}\left\{\mathrm{S}_{1} \cdot \mathrm{S}_{2}\right\}
$$


Using Hatfield's correlation for $\mathrm{Cu}-\mathrm{O}-\mathrm{Cu}$ angle versus exchange [115], $\mathrm{J}_{\text {calc }}=-332 \mathrm{~cm}^{-1}$, it is possible that the azide is responsible for a small ferromagnetic contribution, which would agree with our azide correlation (vide supra) [116,117].

Complex 3 contains a simple dinuclear unit with two in plane active bridges, both connecting the $\mathrm{d}_{\mathrm{x}}{ }^{2}-\mathrm{y}^{2}$ metal magnetic orbitals. The fit is good, indicating overall AF coupling, and gives $\mathrm{g}=2.13(1)$, $\mathrm{J}=-177.3(2) \mathrm{cm}^{-1}$ TIP $=100 \times 10^{-6} \mathrm{~cm}^{3} \mathrm{~mol}^{-1}, \rho=0.004,10^{2} \mathrm{R}=2.41$ (Agreement factor $\mathrm{R}$ is defined as, $\left.\mathrm{R}=\left[\Sigma\left(\chi_{\mathrm{obs}}-\chi_{\mathrm{calc}}\right)^{2} / \Sigma \chi_{\mathrm{obs}}{ }^{2}\right]^{1 / 2}\right)$.

$$
\mathrm{H}_{\mathrm{ex}}=-\mathrm{J}\left\{\mathrm{S}_{1} \cdot \mathrm{S}_{2}\right\}
$$

The $\mathrm{Cu}-\mathrm{O}-\mathrm{Cu}$ angle $\left(100.9^{\circ}\right)$ suggests $\mathrm{AF}$ exchange, while the $\mathrm{Cu}-\mathrm{N}_{3}-\mathrm{Cu}$ angle $\left(100.1^{\circ}\right)$ is just in the Ferromagnetic realm. Since Ferromagnetic (F) and antiferromagnetic (AF) are additive and of opposite sign, one would expect the AF J value to be less than predicted based on Hatfield's correlation. For the $\mathrm{Cu}-\mathrm{O}-\mathrm{Cu}$ angle $\mathrm{J}_{\text {calc }}=\sim-250 \mathrm{~cm}^{-1}$, in complete agreement [115].

Complex 5 breaks down nicely into two isolated parts both expected to be AF. The fit assumes that all $\mathrm{J}$ values are the same, which is not unreasonable given the bridges and the $\mathrm{Cu}-\mathrm{O}-\mathrm{Cu}$ angles. The benzoates are not influencing exchange in any significant way.

$$
\mathrm{H}_{\mathrm{ex}}=-\mathrm{J}\left\{\mathrm{S}_{1} \cdot \mathrm{S}_{2}+\mathrm{S}_{2} \cdot \mathrm{S}_{3}+\mathrm{S}_{1} \cdot \mathrm{S}_{3}+\mathrm{S}_{2} \cdot \mathrm{S}_{4}+\mathrm{S}_{5} \cdot \mathrm{S}_{6}+\mathrm{S}_{6} \cdot \mathrm{S}_{7}\right\}
$$

The fit is good, giving $\mathrm{g}=2.09(2), \mathrm{J}_{\mathrm{av}}=-204(7) \mathrm{cm}^{-1}, \mathrm{TIP}=340 \times 10^{-1} \mathrm{~cm}^{3} \mathrm{~mol}^{-1}, \theta=-0.6 \mathrm{~K}$, $10^{2} \mathrm{R}=2.96$.

For clarity, the structure of $\mathbf{5}$ showing only the metal centers and the coordinating atoms is shown in Figure 15.

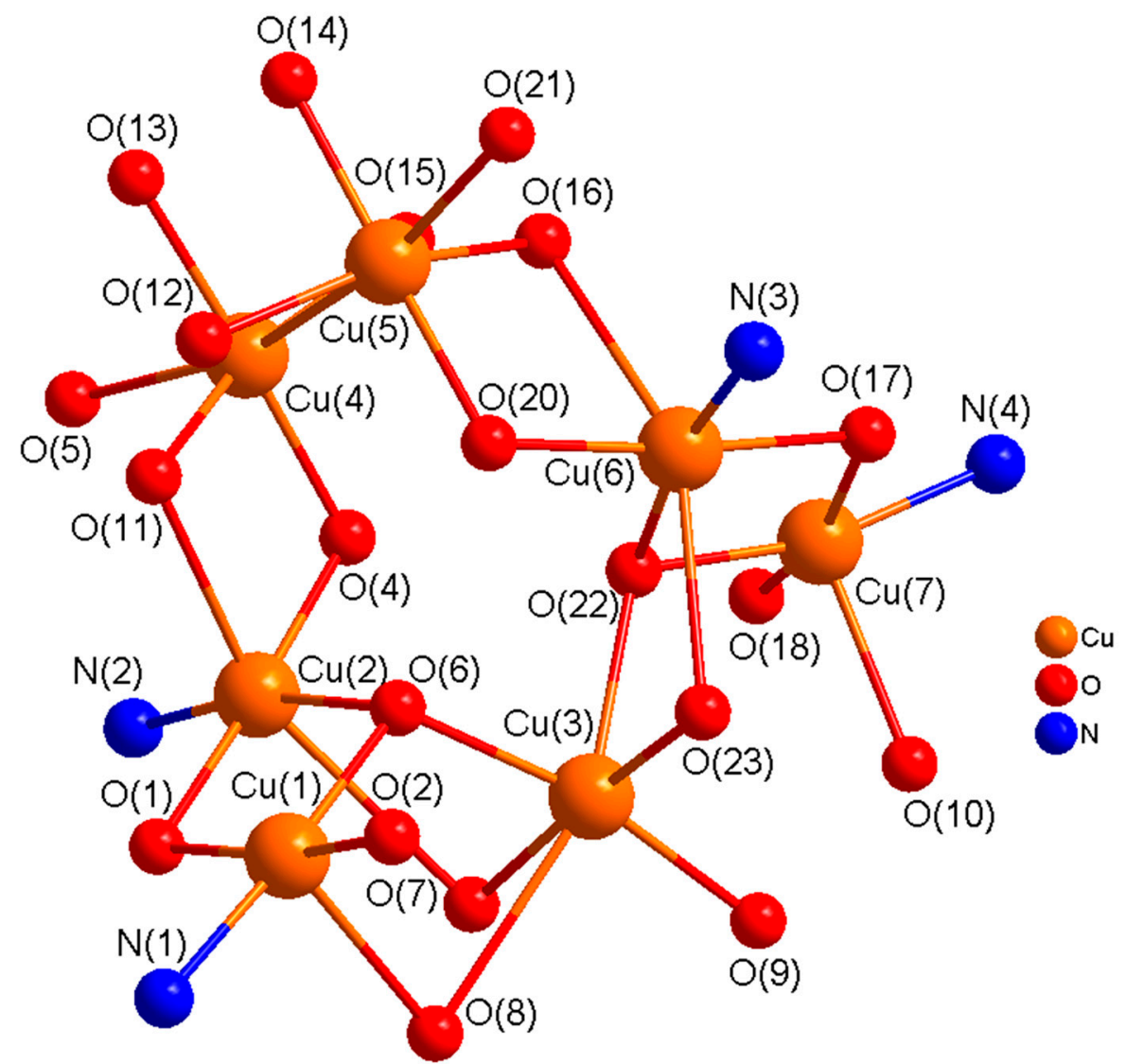

Figure 15. The structure of 5 showing only the copper atoms and the donor atoms. 


\subsection{Magneto-Structural Relationships}

In doubly bridged $\left[\mathrm{Cu}_{2}(\mu-\mathrm{OPh})\left(\mu-1,1-\mathrm{N}_{3}\right)\right]$ copper(II) complexes, the nature (ferromagnetic/ antiferromagnetic) and the magnitude of the magnetic spin exchange interaction (J) depends primarily on the bridge angles, but other important factors such as the intermetallic distance (d), bond distance in the equatorial plane, stereochemistry, and distortion from planarity in the mean plane of dinuclear core can also influence the magnitude of the coupling constant (J) [118]. In order to illustrate the magneto-structural trends, we have compiled the magnetic data of all the copper(II) complexes (Table 1) from the literature that contain endogenous phenoxide bridge and exogenous $\mathrm{EO} \mu$-azido bridge along with two new compounds (1 and 3 ) reported in this study. The relationships between the antiferromagnetic coupling constant $(-\mathrm{J})$ and phenoxide bridge angle $(\mathrm{Cu}-\mathrm{PhO}-\mathrm{Cu})$, average bridge angles of $\mu$-phenoxide bridges and $\mu$-azido bridges, and the $\mathrm{Cu}-\mathrm{Cu}$ distance $(\mathrm{d})$ are represented in Figures 16-18 respectively, and summarized in Table 1.

Table 1. Magneto-chemical parameters for the $\mu$-phenolate dicopper complexes with $\mu$-azido as exogenous bridge.

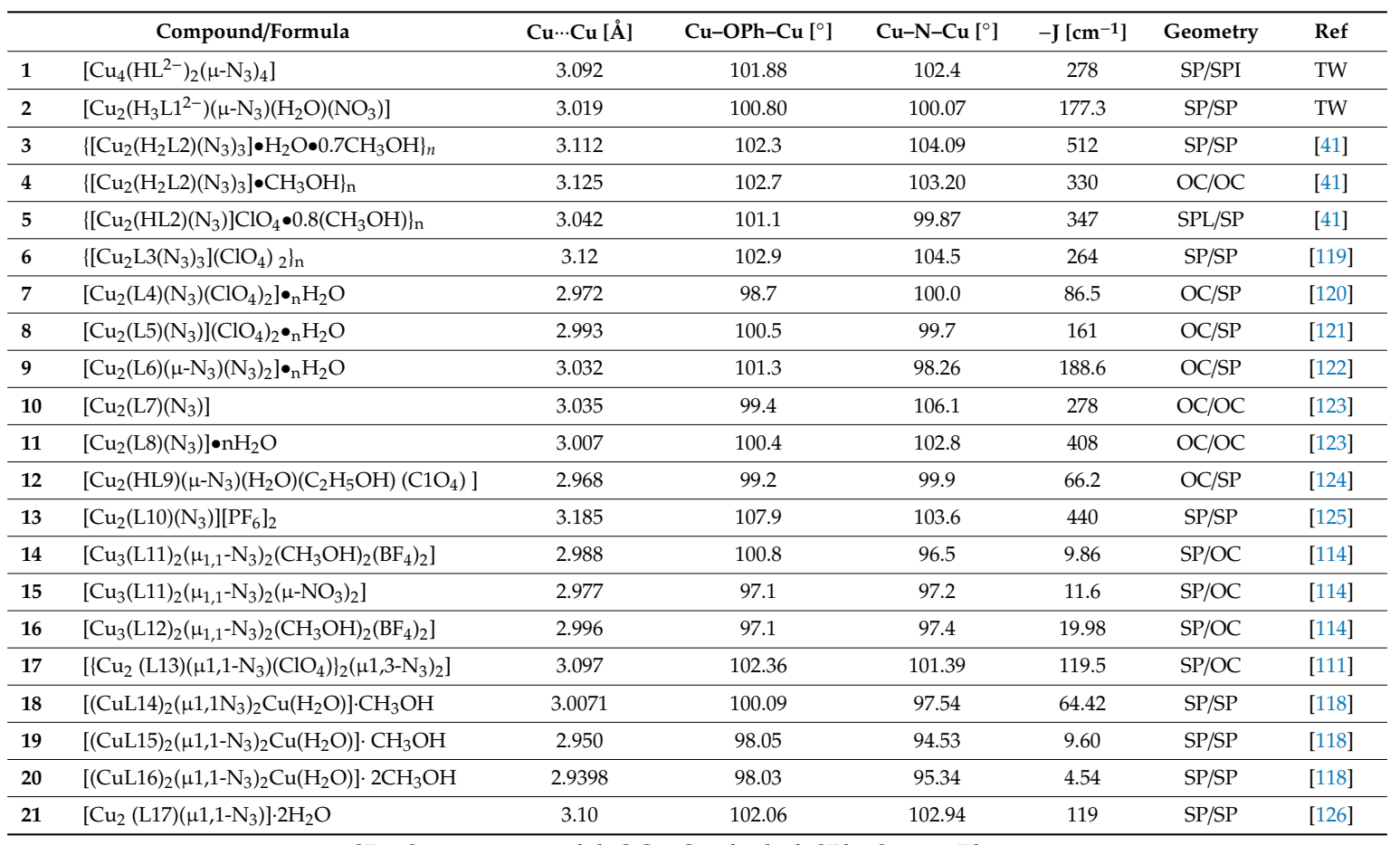




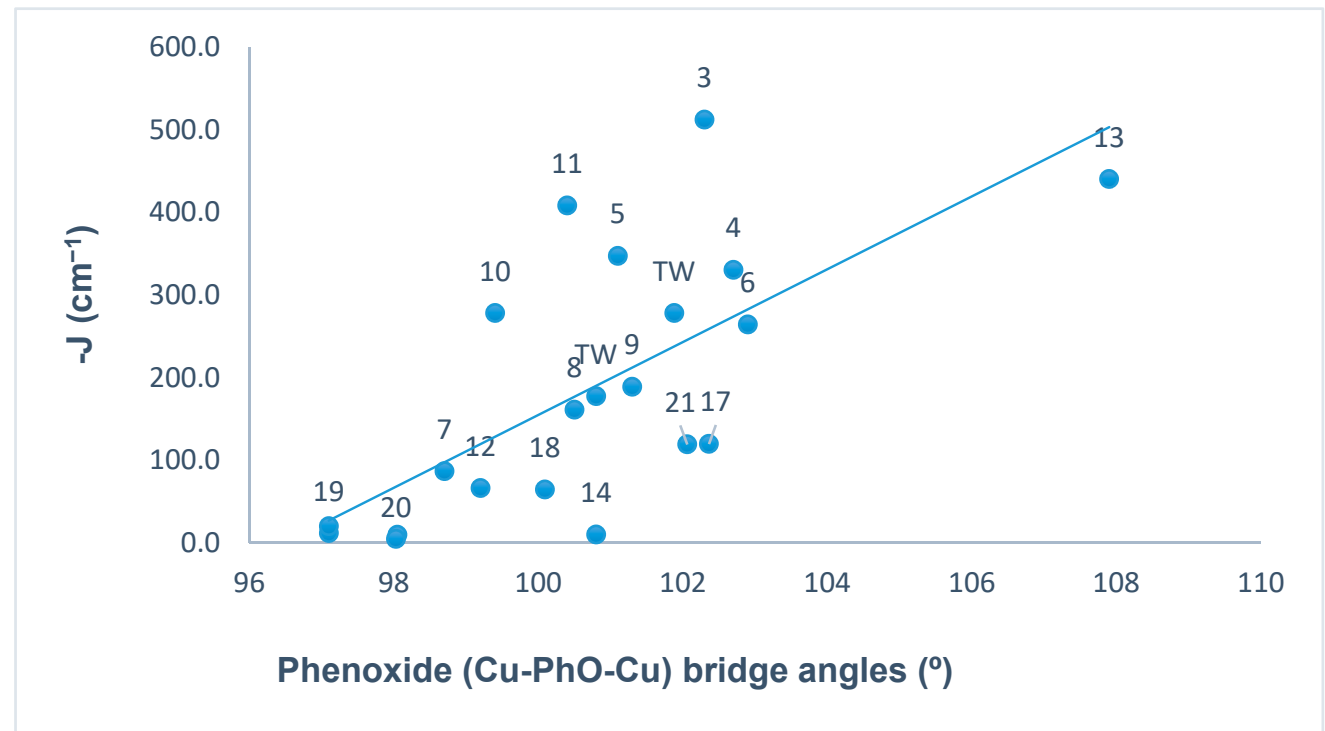

Figure 16. Plot of the antiferromagnetic interaction $(-\mathrm{J})$ vs. the $\mathrm{Cu}-\mathrm{OPh}-\mathrm{Cu}$ angle in dinuclear. ( $\mu$-phenolate/ $\mu$-azido bridged) copper(II) complexes.

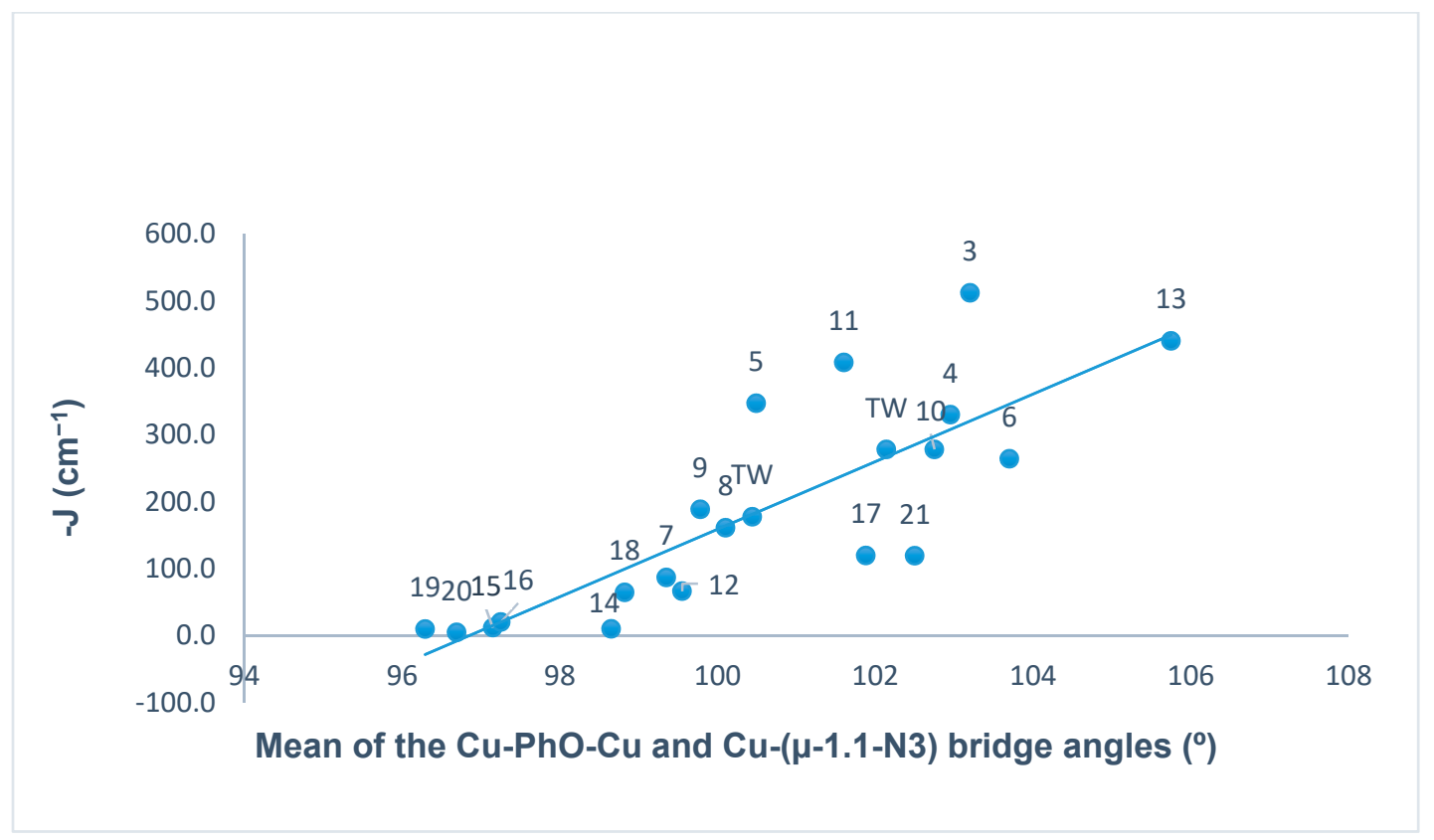

Figure 17. Plot of the antiferromagnetic interaction $(-\mathrm{J})$ vs. the averaged $\mathrm{Cu}-\mathrm{OPh}-\mathrm{Cu}$ and $\mathrm{Cu}-\left(\mu-\mathrm{N}_{3}\right)$ angle in dinuclear ( $\mu$-phenolate/ $\mu$-azido bridged) copper(II) complexes. 


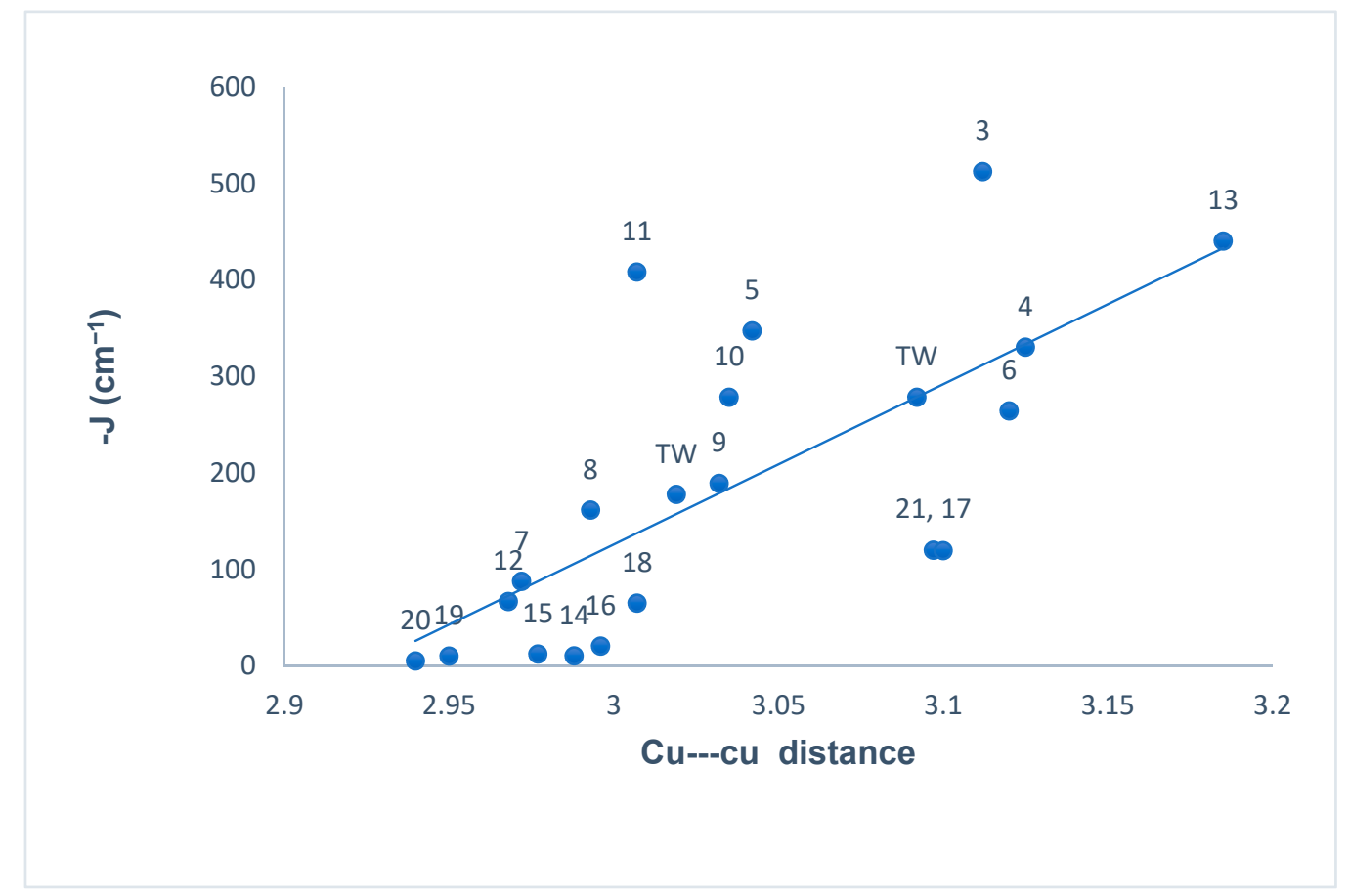

Figure 18. Plot of the antiferromagnetic interaction $(-\mathrm{J})$ vs. the $\mathrm{Cu}-\mathrm{Cu}$ distance $(\mathrm{d})$ in dinuclear ( $\mu$-phenolate/ $\mu$-azido bridged) copper(II) complexes.

$\mathrm{H}_{3} \mathrm{~L}$ and $\mathrm{H}_{5} \mathrm{~L} 1$ are the ligands used in this publication. $\mathrm{H}_{3} \mathrm{~L} 2$, 2,6-bis[[(2-hydroxyethyl) imino] methyl]-4-methylphenol. L3, Schiff base of 2-hydroxy-5-methylisophthalaldehyde and dimethylamino1-propylamine. L4 (Fdmen), Schiff base of 2,6-diformyl-4-methylphenol with 1,1dimethylethylenediamine. L5 (Fmap), 2,6-bis( $N$-(2-pyridylmethyl) formimidoyl)-4-methylphenolate. L6, Schiff-base of 4-methyl-2,6-diformylphenol and the 1,2-diaminoethane. L7, 4-methyl-2,6bis[N-(2-pyridylethyl)formimidoyl]phenolate. L8, 4-Methyl-2,6-bis[N-(2-methylthioethyl) formimidoyl] phenolate. L9, 2,6-diformyl-4-methyl phenol-di(benzoylhydrazone). L10, 2,6-bis(dipyridylmino)phenol. L11, 2-[1-(2-dimethylamino-ethylimino)-ethyl]-phenol. L12, 2-[1-(2-diethylamino-ethylimino)-ethyl]phenol. L13 = 2,6-bis[N-(2-pyridylethyl)formidoyl]-4-ethylphenol. L14, N,N-bis(3,5-dimethyl-2hydroxybenzyl)- $N^{\prime}, N^{\prime}$-dimethyl-1,3-diaminopropane. L15, $N, N$-bis(3,5-dimethyl-2-hydroxybenzyl)$N^{\prime}, N^{\prime}$-dimethyl-1,2-diaminoethane. L16, $N, N$-bis(3,5-dimethyl-2-hydroxybenzyl)- $N^{\prime}, N^{\prime}$-diethyl-1,2diaminoethane. L17, 2,6-bis[\{[(2-hy-droxybenzyl)(N,N-(dimethylamino)ethyl]amino\} methyl]4-methylphenol.

For the two complexes ( $\mathbf{1}$ and $\mathbf{3}$, in Table 1, $\mathbf{1}$ and $\mathbf{2})$ reported in this study, a strong antiferromagnetic interaction $\left(-\mathrm{J}=278,177.3 \mathrm{~cm}^{-1}\right.$ respectively) occurs within the dinuclear $\left[\mathrm{Cu}_{2}(\mu-\mathrm{OPh})\left(\mu-1,1-\mathrm{N}_{3}\right)\right]$ core where the $\mathrm{Cu}-\mathrm{N}$ and $\mathrm{Cu}-\mathrm{O}$ distances in the equatorial plane fall in the ranges of 1.915-1.980 $\AA$ and 1.9341-1.998 A respectively. These are quite short and are within the plane of the magnetic orbitals of both metals $\left(\mathrm{dx}^{2}-\mathrm{y}^{2}\right)$ which are approximately parallel, and are responsible for effective coupling between copper(II) centers in each dinuclear unit. Based on the bridge angles, it is anticipated that the bridging moieties ( $\mu$-phenolato and $\mu$-azido) provide counter complementary contributions to the magnetic exchange interaction between the copper(II) centers in $\left[\mathrm{Cu}_{2}(\mathrm{OPh})\left(\mu-1,1-\mathrm{N}_{3}\right)\right]$ core $[127,128]$.

The phenoxide bridge angle of $101.88^{\circ}(\mathbf{1}) / 100.80^{\circ}(3)$ and the $\mu$-azido bridge angles of $102.4^{\circ}$ (1) $/ 100.07^{\circ}$ (3) in these complexes are expected to mediate antiferromagnetic and ferromagnetic spin coupling respectively between the copper centers, based on previous studies [111,118]. This is consistent with the reported data for $\mu$-phenolato/ $\mu$-azido bridged copper(II) complexes presented in Figures 16 and 17. It is a well- established fact that for bis( $\mu$-phenolato) bridged copper(II) complexes if the bridge angle is less than the critical angle of $\sim 97^{\circ} / 98^{\circ}$, the spin coupling constant (J) between the copper centers is dominantly ferromagnetic, and for larger angles an antiferromagnetic interaction is 
expected [36,129]. For dinuclear complexes involving a $\mu$-azido bridge, it has been established that the nature of the spin coupling constant $(J)$ is dependent on the $\mathrm{Cu}-\left(\mu-\mathrm{N}_{3}\right)-\mathrm{Cu}$ bridge angle, and that the magnitude of ferromagnetic coupling $\left(\mathrm{J}_{\text {ferro }}\right.$ ) decreases with increasing bridge angle (critical angle $104^{\circ}$ (according to theoretical calculation) [130] or $108^{\circ}$ (experimental studies) $[115,116]$ ).

The antiferromagnetic spin coupling constant $(-\mathrm{J})$ plotted against the phenolate bridge angle and the averaged bridge angle of phenolate and azido for all the reported copper(II) complexes is shown in Figures 16 and 17 respectively. Figure 16 shows a relationship between -J and phenolate bridge angles with reasonable linear character. A graph of $-\mathrm{J}$ vs. averaged bond angles (Figure 17) shows a much better linear trend between coupling constant $-\mathrm{J}$ and averaged bridge angles for majority of the complexes including two in the present study, with only a few exceptions. The complexes (1 and $\mathbf{3})$ reported in this study lie close to the line of best fit. In these double bridged (phenoxide and end-on azido) copper(II) complexes, the averaged bridge angles lies in the range $96.29-105.75^{\circ}$ and the coupling constant (-J) lies in the range, $\mathrm{J}=-4.54 \mathrm{~cm}^{-1}$ for small angle $\left(96.69^{\circ}\right)$ to $\mathrm{J}=-440 \mathrm{~cm}^{-1}$ for the large angle $\left(105.75^{\circ}\right)$ with the exception of compound 3 in Table 1 where the average bridge angle is $103.20^{\circ}$ and $\mathrm{J}=-512 \mathrm{~cm}^{-1}$. While these plots show realistic trends, with dominant linear character, it is necessary to stress that the J values are based on the sum of two counter-complementary exchange contributions, where the individual bridges have linear variations with angle, which are different. This helps to explain why the general appearance of the averaged data plotted in Figure 17 look more linear than those in Figure 16.

Figure 18 summarizes the trend in exchange integral as a function of $\mathrm{Cu}-\mathrm{Cu}$ distance listed in Table 1. A reasonably linear relationship is evident for majority of the complexes. This agrees with the expected increase in both bridge angles, resulting in an increase of the antiferromagnetic contribution as reported previously $[36,41,115,116,129,130]$.

\subsection{Powder X-ray Diffraction Studies}

In an attempt to characterize the bulk powder, the XRD patterns of 1, $\mathbf{3}$ and 5 were collected. (Figures S3-S5). The XRD patterns were collected and compared to the calculated pattern generated from the single-crystal X-ray structure [131]. For $\mathbf{3}$ and 5, the form of the diffraction curve for the observed pattern was similar to that of the calculated pattern. There were minor differences (i.e., intensity variations, changes in peak full-width, and peak position) between the calculated and observed peaks. Peak shifts are an artifact, given that the powder data were collected at room temperature, while the calculated pattern was based on structural data from $-100^{\circ} \mathrm{C}$. This difference may change the unit cell dimensions and shift peak positions along the $2 \theta$ axis. For 1 , peak differences may result from the sample being grinded prior to characterizing. Mechanical grinding could alter the crystallite structure, possibly through the loss of solvent in the lattice. Although the XRD powder pattern shows consistency to that of the calculated powder pattern, the measurement also does not reveal amorphous content that may be present within the sample. Hence, the XRD powder data are not useful for commenting on the purity of the crystalline phase(s) present.

\section{Materials and Methods}

\subsection{Physical Measurements}

Infrared spectra were recorded as Nujol mulls using a Perkin Elmer FT-IR instrument, and Uv/Vis spectra of the powdered compounds were obtained as Nujol mulls or in solution using a Cary 5E spectrometer. Micro-analyses were carried out using a Leco CHNS-Analyzer. Variable temperature magnetic data (2-300 K) were obtained using a Quantum Design MPMS5S SQUID magnetometer with a field strength $0.1 \mathrm{~T}$. Background corrections for the sample holder assembly and diamagnetic components of the complexes were applied. X-ray powder patterns were collected using a Rigaku Miniflex $600 \mathrm{X}$-ray Diffractometer. The radiation used was $\mathrm{Cu} \mathrm{K} \alpha$ radiation $(\lambda=1.54059 \AA)$. 


\subsection{Material}

First, 2,6-Diformyl-4-methylphenol (DFMP) was isolated using the reported method [132]; 1-amino-2-propanol (AP), and 2-amino-1,3-propanediol (APD) were supplied by Aldrich. All other chemicals used (solvents and metal salts) were analytical or reagent grade and were employed without further purification. Schiff base ligands were prepared in situ by metal catalyzed self-assembly.

\subsection{Synthesis of the Coordination Complexes}

Caution: Azide and perchlorate complexes of metal ions involving organic ligands are potentially explosive. Only small quantities of the complexes should be prepared, and these should be handled with care.

In some cases, there is a difference between the most reasonable formula based on the elemental analysis (analytical formula) and that obtained from X-ray crystallography. In these compounds the $\mathrm{CHN}$ analysis showed a different number of solvent molecules (methanol and water) compared with the X-ray formulae, as the analysis was carried out on air dried samples due to their potential explosive nature. For consistency, the $\mathrm{X}$-ray formulae will be used in the discussion. For compound 1, the X-ray formula is $\left[\mathrm{Cu}_{4}\left(\mathrm{HL}^{2-}\right)_{2}\left(\mathrm{~N}_{3}\right)_{4}\right] \cdot 4 \mathrm{CH}_{3} \mathrm{OH} \cdot 56 \mathrm{H}_{2} \mathrm{O}$ and the analysis formula is $\left[\mathrm{Cu}_{4}\left(\mathrm{HL}^{2-}\right)_{2}\left(\mathrm{~N}_{3}\right)_{4}\right] \cdot 6 \mathrm{H}_{2} \mathrm{O}$. For compound 2, the X-ray formula is $\left[\mathrm{Cu}_{4}\left(\mathrm{HL}^{2-}\right)_{2}(\mathrm{O})_{2}\left(\mathrm{H}_{2} \mathrm{O}\right)_{2}\right]$ and the analysis formula is $\left[\mathrm{Cu}_{4}\left(\mathrm{HL}^{2-}\right)_{2}(\mathrm{O})_{2}\left(\mathrm{H}_{2} \mathrm{O}\right)_{2}\right] \cdot 12 \mathrm{H}_{2} \mathrm{O}$. For compound 3, the X-ray formula is $\left[\mathrm{Cu}_{2}\left(\mathrm{H}_{3} \mathrm{~L}^{2-}\right)\left(\mathrm{H}_{2} \mathrm{O}\right)\left(\mathrm{NO}_{3}\right)\left(\mathrm{N}_{3}\right)\right]$ and the analysis formula is $\left[\mathrm{Cu}_{2}\left(\mathrm{H}_{3} \mathrm{L1}^{2-}\right)\left(\mathrm{H}_{2} \mathrm{O}\right)\left(\mathrm{NO}_{3}\right)\left(\mathrm{N}_{3}\right)\right] \cdot \mathrm{CH}_{3} \mathrm{OH} \cdot 0.8 \mathrm{H}_{2} \mathrm{O}$. For compound 5 , the X-ray formula is $\left[\mathrm{Cu}_{7}\left(\mathrm{H}_{3} \mathrm{Lr}^{2-}\right)_{2}(-\mathrm{O})_{2}\left(\mathrm{C}_{6} \mathrm{H}_{5} \mathrm{CO}_{2}\right)_{6}\right] \cdot 6 \mathrm{CH}_{3} \mathrm{OH} \cdot 44 \mathrm{H}_{2} \mathrm{O}$ and the analysis formula is $\left[\mathrm{Cu}_{7}\left(\mathrm{H}_{3} \mathrm{L1}^{2-}\right)_{2}(\mathrm{O})_{2}\left(\mathrm{C}_{6} \mathrm{H}_{5} \mathrm{CO}_{2}\right)_{6}\right] \cdot 10 \mathrm{H}_{2} \mathrm{O}$. For compound 6 , the X-ray formula is $\left[\mathrm{Cu}_{10}\left(\mathrm{H}_{3} \mathrm{L1}^{2-}\right)_{4}(\mathrm{O})_{2}(\mathrm{OH})_{2}\left(\mathrm{C}_{6} \mathrm{H}_{5} \mathrm{CO}_{2}\right)_{4}\right]\left(\mathrm{C}_{6} \mathrm{H}_{5} \mathrm{CO}_{2}\right)_{2} \cdot 20 \mathrm{H}_{2} \mathrm{O}$ and the analysis formula is $\left[\mathrm{Cu}_{10}\left(\mathrm{H}_{3} \mathrm{L1}^{2-}\right)_{4}(\mathrm{O})_{2}(\mathrm{OH})_{2}\left(\mathrm{C}_{6} \mathrm{H}_{5} \mathrm{CO}_{2}\right)_{4}\right]\left(\mathrm{C}_{6} \mathrm{H}_{5} \mathrm{CO}_{2}\right)_{2} \cdot 13 \mathrm{H}_{2} \mathrm{O}$.

\subsection{1. $\left[\mathrm{Cu}_{4}\left(\mathrm{HL}^{2-}\right)_{2}\left(\mathrm{~N}_{3}\right)_{4}\right] \cdot \mathrm{CH}_{3} \mathrm{OH} \cdot 14 \mathrm{H}_{2} \mathrm{O}(\mathbf{1})$}

First, 1-Amino-2-propanol (AP) $(0.08 \mathrm{~g}, 1.0 \mathrm{mmol})$ dissolved in $3 \mathrm{~mL}$ of methanol was added dropwise to a solution of 2,6-diformyl-4-methylphenol (DFMP, $0.09 \mathrm{~g}, 0.50 \mathrm{mmol}$ ) in hot methanol $(10 \mathrm{~mL})$ while stirring under reflux. The yellow solution formed was refluxed for $30 \mathrm{~min}$ and a solution of $\mathrm{Cu}\left(\mathrm{BF}_{4}\right)_{2} \cdot 6 \mathrm{H}_{2} \mathrm{O}(1.0 \mathrm{mmol}, 0.35 \mathrm{~g})$ in methanol $(5 \mathrm{~mL})$ was added dropwise. The reaction mixture (green) was refluxed for $10 \mathrm{~min}$, and a solution of $\mathrm{NaN}_{3}(0.07 \mathrm{~g}, 1.0 \mathrm{mmol})$ in a hot methanol $(10 \mathrm{~mL})$ was added dropwise. The color of the reaction mixture changed to dark green and it was refluxed further for $2.0 \mathrm{~h}$. The green solution was filtered hot, and the filtrate was kept unperturbed at room temperature for slow evaporation. After two weeks, dark green crystals suitable for X-ray studies were obtained and some were kept in the mother liquor for X-ray analysis. The bulk sample was separated from the mother liquor and washed with methanol $(2 \times 2 \mathrm{~mL})$ and air dried at ambient temperature. IR spectrum: $3423 \mathrm{~cm}^{-1}\left(v(\mathrm{OH}) \mathrm{H}_{2} \mathrm{O}\right.$ and $\left.\mathrm{CH}_{3} \mathrm{OH}\right), 2093,2037 \mathrm{~cm}^{-1}$ (vas $\left.\left(\mathrm{N}_{3}\right)\right), 1637 \mathrm{~cm}^{-1}(v(\mathrm{C}=\mathrm{N})$ ). UV-Vis Spectrum: $330 \mathrm{~nm}(\mathrm{~s}), 370 \mathrm{~nm}(\mathrm{sh})$ (Cu-azide and Cu-ligand charge transfer transitions respectively), and $625 \mathrm{~nm}$ (d-d transition). Yield: $0.14 \mathrm{~g}, 48 \%$, based on DFMP. Elemental analysis (air dried sample): Found (\%): C, 32.95; $\mathrm{H}, 4.97 ; \mathrm{N}, 21.14$. Calcd (\%) for $\left[\mathrm{Cu}_{4}\left(\mathrm{C}_{15} \mathrm{H}_{20} \mathrm{~N}_{2} \mathrm{O}_{3}\right)_{2}\left(\mathrm{~N}_{3}\right)_{4}\right] \cdot 6 \mathrm{H}_{2} \mathrm{O}$, C, 33.33; H, 4.85; N, 20.74.

\subsection{2. $\left[\mathrm{Cu}_{4}\left(\mathrm{~L}^{3-}\right)_{2}(\mathrm{OH})_{2}\left(\mathrm{H}_{2} \mathrm{O}\right)_{2}\right] \cdot \mathrm{CH}_{3} \mathrm{OH} \cdot 11 \mathrm{H}_{2} \mathrm{O}(2)$}

Complex 2 was prepared by exactly the same method as used for 1 by replacing $\mathrm{Cu}\left(\mathrm{BF}_{4}\right)_{2} \cdot 6 \mathrm{H}_{2} \mathrm{O}$ with $\mathrm{CuCl}_{2} \cdot 6 \mathrm{H}_{2} \mathrm{O}$ and adding 10 drops of triethylamine in the absence of $\mathrm{NaN}_{3}$. Dark green crystals suitable for $\mathrm{x}$-analysis were obtained by keeping the reaction mixture unperturbed at ambient temperature for 5 weeks. IR spectrum: $3450 \mathrm{~cm}^{-1}, 3341 \mathrm{~cm}^{-1}\left(v(\mathrm{OH}) \mathrm{H}_{2} \mathrm{O}\right.$ and $\left.\mathrm{CH}_{3} \mathrm{OH}\right), 1652 \mathrm{~cm}^{-1}, 1637 \mathrm{~cm}^{-1}(v(\mathrm{C}=\mathrm{N}))$. UV-Vis Spectrum: $375 \mathrm{~nm}$ (Cu-ligand charge transfer transitions) and $735 \mathrm{~nm}$ (d-d transition). Yield: 0.085 g, 40\%, based on DFMP. Elemental analysis (air dried sample): Found (\%): C,32.75; H, 5.86; N, 5.48. Calcd (\%) for $\left[\mathrm{Cu}_{4}\left(\mathrm{C}_{15} \mathrm{H}_{19} \mathrm{~N}_{2} \mathrm{O}_{3}\right)_{2}\left((\mathrm{OH})_{2}\left(\mathrm{H}_{2} \mathrm{O}\right)_{2}\right] \cdot 12 \mathrm{H}_{2} \mathrm{O}: \mathrm{C}, 33.02 ; \mathrm{H}, 6.28 ; \mathrm{N}, 5.14\right.$. 


\subsection{3. $\left[\mathrm{Cu}_{2}\left(\mathrm{H}_{3} \mathrm{~L}^{2-}\right)\left(\mathrm{N}_{3}\right)\left(\mathrm{H}_{2} \mathrm{O}\right)\left(\mathrm{NO}_{3}\right)\right](3)$}

First, 2,6-Diformyl-4-methylphenol (DFMP, $0.09 \mathrm{~g}$, $0.50 \mathrm{mmol}$ ) dissolved in hot methanol $(10 \mathrm{~mL})$ was added to a solution of 2-amino-1,3-propanediol (APD) $(0.09 \mathrm{~g}, 1.0 \mathrm{mmol})$ in the same solvent $(5 \mathrm{~mL})$. The yellow solution of the Schiff-base ligand $\left(\mathrm{H}_{5} \mathrm{~L} 1\right)$ formed was stirred under reflux for $30 \mathrm{~min}$, and a solution of $\mathrm{Cu}\left(\mathrm{NO}_{3}\right)_{2} \cdot 3 \mathrm{H}_{2} \mathrm{O}(0.24 \mathrm{~g}, 1.0 \mathrm{mmol})$ in methanol $(5 \mathrm{~mL})$ was added to it dropwise. The solution changed from brown to green in about $5 \mathrm{~min}$. The resulting green solution was refluxed for $10 \mathrm{~min}$ and a solution of $\mathrm{NaN}_{3}(0.070 \mathrm{~g}, 1.0 \mathrm{mmol})$ in hot methanol $(10 \mathrm{~mL})$ was added dropwise. The color of the reaction mixture changed to dark green and was refluxed further for $1.5 \mathrm{~h}$. A clear green solution was filtered hot and the filtrate was left undisturbed at ambient temperature for slow evaporation. After four weeks, dark green crystals suitable for x-ray analysis were formed, separated from the mother liquor, and washed with methanol $(2 \times 2 \mathrm{~mL})$. IR spectrum: $3392,3322 \mathrm{~cm}^{-1}\left(v(\mathrm{OH}) \mathrm{H}_{2} \mathrm{O}\right), 2110$, $2074,2050 \mathrm{~cm}^{-1}\left(\right.$ vas $\left.\left(\mathrm{N}_{3}\right)\right), 1648,1634 \mathrm{~cm}^{-1}(v(\mathrm{C}=\mathrm{N}))$. UV-Vis Spectrum: $378 \mathrm{~nm}(\mathrm{~s})$, and $410 \mathrm{~nm}(\mathrm{sh})$ (Cu-azide and $\mathrm{Cu}$-ligand charge transfer transitions respectively), and $625 \mathrm{~nm}$ (d-d transition). Yield: $0.16 \mathrm{~g}, 54 \%$, based on DFMP. Elemental analysis (air dried sample): Found (\%): C, 31.73; H, 3.97; N, 13.46. Calcd (\%) for $\left[\mathrm{Cu}_{2}\left(\mathrm{C}_{15} \mathrm{H}_{19} \mathrm{~N}_{2} \mathrm{O}_{5}\right)\left(\mathrm{H}_{2} \mathrm{O}\right)\left(\mathrm{NO}_{3}\right)\left(\mathrm{N}_{3}\right)\right] \cdot \mathrm{CH}_{3} \mathrm{OH} \cdot 0.8 \mathrm{H}_{2} \mathrm{O}: \mathrm{C}, 31.87 ; \mathrm{H}, 4.45 ; \mathrm{N}, 13.94$.

\subsection{4. $\left\{\left[\mathrm{Cu}_{2}\left(\mathrm{H}_{3} \mathrm{~L}^{2-}\right)\left(\mathrm{H}_{2} \mathrm{O}\right)\left(\mathrm{BF}_{4}\right)\left(\mathrm{N}_{3}\right)\right] \cdot \mathrm{H}_{2} \mathrm{O}\right\}_{\mathrm{n}}(4)$}

Compound 4 was obtained in a similar manner as compound 3. In this case after adding the $\mathrm{NaN}_{3}$ solution to the reaction mixture of DFMP (0.50 mmol), 2-amino-1,3-propanediol (1.0 mmol), and $\mathrm{Cu}\left(\mathrm{BF}_{4}\right)_{2} \cdot 6 \mathrm{H}_{2} \mathrm{O}(0.35 \mathrm{~g}, 1.0 \mathrm{mmol})$, the mixture was further refluxed for $2.0 \mathrm{~h}$ and left at room temperature undisturbed for slow evaporation. After one week, very nice crystals suitable for X-ray studies separated from the dark green solution. The crystals used for X-ray studies were kept in the mother liquor. The remaining crystals were separated and washed with methanol $(2 \times 2 \mathrm{~mL})$. IR spectrum: $3361 \mathrm{~cm}^{-1}\left(v(\mathrm{OH}) \mathrm{H}_{2} \mathrm{O}\right), 2114 \mathrm{~cm}^{-1}, 2080 \mathrm{~cm}^{-1}\left(\right.$ vas $\left.\left(\mathrm{N}_{3}\right)\right), 1646 \mathrm{~cm}^{-1}, 1635 \mathrm{~cm}^{-1}(v(\mathrm{C}=\mathrm{N}))$. UV-Vis Spectrum: $327 \mathrm{~nm}$, and $370 \mathrm{~nm}$ (Cu-azide and $\mathrm{Cu}$-ligand charge transfer transitions respectively), and $625 \mathrm{~nm}$ (d-d transition). (Yield: $0.18 \mathrm{~g}, 54 \%$ ). Elemental analysis: Found (\%): C, 30.50; H, 4.11; N, 11.44. Calcd (\%) for $\left\{\left[\mathrm{Cu}_{2}\left(\mathrm{C}_{15} \mathrm{H}_{19} \mathrm{~N}_{2} \mathrm{O}_{5}\right)\left(\mathrm{H}_{2} \mathrm{O}\right)\left(\mathrm{BF}_{4}\right)\left(\mathrm{N}_{3}\right)\right] \cdot \mathrm{H}_{2} \mathrm{O}\right\}_{n}: \mathrm{C}, 30.01 ; \mathrm{H}, 3.87 ; \mathrm{N}, 11.69$.

\subsection{5. $\left[\mathrm{Cu}_{7}\left(\mathrm{H}_{3} \mathrm{L1}^{2-}\right)_{2}(\mathrm{O})_{2}\left(\mathrm{C}_{6} \mathrm{H}_{5} \mathrm{CO}_{2}\right)_{6}\right] \cdot 6 \mathrm{CH}_{3} \mathrm{OH} \cdot 44 \mathrm{H}_{2} \mathrm{O}(5)$}

First, 2,6-Diformyl-4-methylphenol ( $0.17 \mathrm{~g}, 1.0 \mathrm{mmol})$ dissolved in hot methanol $(15 \mathrm{~mL})$ was added to a solution of 2-amino-1,3-propanediol (APD) $(0.18 \mathrm{~g}, 2.0 \mathrm{mmol})$ in methanol $(10 \mathrm{~mL})$. The yellow solution of the Schiff-base ligand $\left(\mathrm{H}_{5} \mathrm{~L} 1\right)$ was then refluxed for $30 \mathrm{~min}$ and $\mathrm{Cu}\left(\mathrm{ClO}_{4}\right)_{2} \cdot 6 \mathrm{H}_{2} \mathrm{O}(0.92 \mathrm{~g}$, $0.25 \mathrm{mmol})$ dissolved in hot methanol $(10 \mathrm{~mL})$ was added to it dropwise with stirring under reflux. The bright green solution formed was refluxed further for $10 \mathrm{~min}$ and a solution of sodium benzoate $\left(\mathrm{C}_{6} \mathrm{H}_{5} \mathrm{CO}_{2} \mathrm{Na}\right)(0.30 \mathrm{~g}, 2.0 \mathrm{mmol})$ in hot methanol $(15 \mathrm{~mL})$ was added dropwise. After refluxing the reaction mixture for $10 \mathrm{~min}$, a solution of triethylamine $(0.20 \mathrm{~g}, 2.0 \mathrm{mmol})$ dissolved in $5 \mathrm{~mL}$ of methanol was added dropwise, which caused a color change of the reaction mixture to brownish green. It was stirred under reflux for $2.0 \mathrm{~h}$ and filtered hot. The filtrate was left unperturbed at ambient temperature for slow evaporation. After three weeks some colorless crystals, which were possibly of sodium benzoate, separated and were filtered off. $5 \mathrm{~mL}$ of ethanol and $2 \mathrm{~mL}$ of water was added to the filtrate and left at room temperature for slow evaporation. After two weeks green crystals suitable for X-ray analysis formed and were kept in the mother liquor. The crystals of the bulk sample were separated from the mother liquor and washed with methanol $(2 \times 2 \mathrm{~mL})$. IR spectrum: $3400 \mathrm{~cm}^{-1}\left(v(\mathrm{OH}) \mathrm{H}_{2} \mathrm{O}\right.$ and $\left.\mathrm{CH}_{3} \mathrm{OH}\right), 1645,1608 \mathrm{~cm}^{-1}(v(\mathrm{C}=\mathrm{N}))$. UV-Vis Spectrum: $330 \mathrm{~nm}$ and $370 \mathrm{~nm}$ (Cu-azide and $\mathrm{Cu}$-ligand charge transfer transitions respectively), and $630 \mathrm{~nm}(\mathrm{~d}-\mathrm{d}$ transition). Yield: $0.45 \mathrm{~g}, 43 \%$ based on DFMP. Elemental analysis on the bulk air-dried sample: Found (\%): C, 42.77; H, 4.03; N, 2.54. Calcd (\%) for $\left[\mathrm{Cu}_{7}\left(\mathrm{C}_{15} \mathrm{H}_{20} \mathrm{~N}_{2} \mathrm{O}_{5}\right)_{2}(\mathrm{O})_{2}\left(\mathrm{C}_{6} \mathrm{H}_{5} \mathrm{CO}_{2}\right)_{6}\right] \cdot 10 \mathrm{H}_{2} \mathrm{O}: \mathrm{C}, 43.23 ; \mathrm{H}, 4.53 ; \mathrm{N}, 2.80$. 


\subsection{6. $\left[\mathrm{Cu}_{10}\left(\mathrm{H}_{3} \mathrm{L1}^{2-}\right)_{4}(\mathrm{O})_{2}(\mathrm{OH})_{2}\left(\mathrm{C}_{6} \mathrm{H}_{5} \mathrm{CO}_{2}\right)_{4}\right]\left(\mathrm{C}_{6} \mathrm{H}_{5} \mathrm{CO}_{2} \mathrm{H}\right)_{2} \cdot 20 \mathrm{H}_{2} \mathrm{O}(\mathbf{6})$}

Complex 6 was prepared by using the same method as used for 5 by reacting $\mathrm{Cu}\left(\mathrm{NO}_{3}\right)_{2} \cdot 3 \mathrm{H}_{2} \mathrm{O}$ $(0.58 \mathrm{~g}, 3 \mathrm{mmol})$ with the Schiff base prepared by reacting 2,6-diformyl-4-methyphenol $(0.17 \mathrm{~g}$, $1 \mathrm{mmol})$ and 2-amino-1,3-propanediol $(0.18 \mathrm{~g}, 2.0 \mathrm{mmol}), \mathrm{C}_{6} \mathrm{H}_{5} \mathrm{CO}_{2} \mathrm{Na}(0.30 \mathrm{~g}, 2.0 \mathrm{mmol})$, and triethylamine $(0.22 \mathrm{~g}, 2.2 \mathrm{mmol})$. IR spectrum: $3289 \mathrm{~cm}^{-1}\left(v(\mathrm{OH}) \mathrm{H}_{2} \mathrm{O}\right), 1644,1628 \mathrm{~cm}^{-1}$ $(v(C=N))$. UV-Vis Spectrum: $320 \mathrm{~nm}(\mathrm{Cu}$-ligand charge transfer transitions respectively), and $638 \mathrm{~nm}$ (d-d transition). Yield: 0.26 g, 35\%, based on DFMP. Found (\%): C, 42.01; H, 4.93; N, 4.20. Calcd. for $\left[\mathrm{Cu}_{10}\left(\mathrm{H}_{3} \mathrm{~L} 1\right)_{4}(\mathrm{O})_{2}(\mathrm{OH})_{2}\left(\mathrm{C}_{6} \mathrm{H}_{5} \mathrm{CO}_{2}\right)_{4}\right]\left(\mathrm{C}_{6} \mathrm{H}_{5} \mathrm{CO}_{2}\right)_{2} \cdot 13 \mathrm{H}_{2} \mathrm{O}: \mathrm{C}, 42.31 ; \mathrm{H}, 4.80 ; \mathrm{N}, 3.87 .3$.

\subsection{X-ray Crystallography}

Suitable single crystals for X-ray diffraction studies were obtained for 1-6. Crystal data for the compounds were collected by the same method by mounting a crystal onto a thin glass fiber from a pool of Fluorolube ${ }^{\mathrm{TM}}$ and immediately placing it under a liquid $\mathrm{N}_{2}$ cooled stream on a Bruker AXS diffractometer upgraded with an APEX II CCD detector. The radiation used was graphite monochromatized Mo K $\alpha$ radiation $(\lambda=0.7107 \AA)$. The lattice parameters were optimized from a least-squares calculation on carefully centered reflections. Lattice determination, data collection, structure refinement, scaling, and data reduction were carried out using APEX3 Version 2018.11 software package $[133,134]$. The data were corrected for absorption using the SCALE program within the APEX3 software package $[133,134]$. The structures were solved using SHELXT [135]. This procedure yielded a number of the $\mathrm{C}, \mathrm{N}, \mathrm{Cu}, \mathrm{O}, \mathrm{F}$ and $\mathrm{B}$ atoms. Subsequent Fourier synthesis yielded the remaining atom positions. The hydrogen atoms were fixed in positions of ideal geometry (riding model) and refined within the XSHELL software package [136]. The final refinement of each compound with anisotropic thermal parameters on all nonhydrogen atoms was performed using OLEX2-1.2 [137]. The crystal data for compounds 1-6 are given in Table 2. Crystallographic data for the structures has been deposited with the Cambridge Crystallographic Data Centre as supplementary publication nos: CCDC 1944278-1944283. Copies of the data can be obtained, free of charge on application to CCDC, 12 Union Road, Cambridge CB2 1EZ, UK (fax, +44-(0)1223-336033; or e-mail, deposit@ccdc.cam.ac.uk).

Table 2. Summary of crystallographic data for compounds 1-6.

\begin{tabular}{llll}
\hline Compound & $\mathbf{1}$ & $\mathbf{2}$ & $\mathbf{3}$ \\
\hline Empirical formula & $\mathrm{C}_{30} \mathrm{H}_{40} \mathrm{Cu}_{4} \mathrm{~N}_{16} \mathrm{O}_{6}$ & $\mathrm{C}_{30} \mathrm{H}_{44} \mathrm{Cu}_{4} \mathrm{~N}_{4} \mathrm{O}_{10}$ & $\mathrm{C}_{15} \mathrm{H}_{19} \mathrm{Cu}_{2} \mathrm{~N}_{6} \mathrm{O}_{9}$ \\
\hline $\mathrm{M}$ & 974.94 & 874.85 & 554.44 \\
\hline Crystal System & Monoclinic & monoclinic & monoclinic \\
\hline Space group & $\mathrm{C} 2 / \mathrm{c}$ & $\mathrm{C} 2 / \mathrm{c}$ & $\mathrm{P} 2{ }_{1} / \mathrm{c}$ \\
\hline $\mathrm{a} / \AA$ & $27.504(8)$ & $17.6107(10)$ & $10.1607(6)$ \\
\hline $\mathrm{b} / \AA$ & $22.357(8)$ & $11.8828(7)$ & $24.3239(14)$ \\
\hline${ }^{\circ} \mathrm{c} / \AA$ & $7.187(3)$ & $22.8905(17)$ & $8.2923(5)$ \\
\hline$\alpha /{ }^{\circ}$ & & - & \\
\hline$\beta /{ }^{\circ}$ & $93.526(7)$ & $109.0710(10)$ & $94.2440(10)$ \\
\hline$\gamma /{ }^{\circ}$ & & - & $2043.8(2)$ \\
\hline$V / \mathrm{A}^{3}$ & $4798(3)$ & $4527.3(5)$ & 1.802 \\
\hline$\rho_{\text {calcd }}\left(\mathrm{g} \mathrm{cm}{ }^{-3}\right)$ & 1.35 & 1.284 & 190.15 \\
\hline$T / \mathrm{K}$ & 190 & 190 & 4 \\
\hline$Z$ & 4 & 4 & 2.144 \\
\hline$\mu / \mathrm{mm}^{-1}$ & 1.801 & 1.899 & $0.2 \times 0.2 \times 0.15$ \\
\hline $\mathrm{Crystal} \mathrm{size}(\mathrm{mm})$ & $0.4 \times 0.2 \times 0.1$ & $0.5 \times 0.2 \times 0.2$ & \\
\hline
\end{tabular}


Table 2. Cont

\begin{tabular}{|c|c|c|c|}
\hline Compound & 1 & 2 & 3 \\
\hline \multicolumn{4}{|c|}{ Reflections collected: } \\
\hline Total & 18,862 & 17,838 & 16,291 \\
\hline Unique & 4253 & 4004 & 3610 \\
\hline$R_{\text {int }}$ & 0.063 & 0.0193 & 0.0299 \\
\hline Final $R_{1}, w R_{2}$ & $0.0712,0.2090$ & $0.0401,0.12732$ & $0.0265,0.0691$ \\
\hline Compound & 4 & 5 & 6 \\
\hline Empirical formula & $\mathrm{C}_{15} \mathrm{H}_{24} \mathrm{BCu}_{2} \mathrm{~F}_{4} \mathrm{~N}_{5} \mathrm{O}_{7}$ & $\mathrm{C}_{72} \mathrm{H}_{71} \mathrm{Cu}_{7} \mathrm{~N}_{5} \mathrm{O}_{27}$ & $\mathrm{C}_{88} \mathrm{H}_{100} \mathrm{Cu}_{10} \mathrm{~N}_{8} \mathrm{O}_{32}$ \\
\hline $\mathrm{M}$ & 600.28 & 1883.11 & 2417.5 \\
\hline Crystal System & monoclinic & monoclinic & triclinic \\
\hline Space group & $\mathrm{P} 2_{1} / \mathrm{c}$ & $\mathrm{P} 2_{1} / \mathrm{c}$ & $\mathrm{P} \overline{1}$ \\
\hline $\mathrm{a} / \AA ̊$ & $12.730(4)$ & 20.291(3) & $12.835(13)$ \\
\hline $\mathrm{b} / \AA ̊ \AA$ & $8.228(3)$ & $22.194(3)$ & $15.38(2)$ \\
\hline c/ $\AA$ & $20.879(6)$ & $33.076(3)$ & $15.81(2)$ \\
\hline$\alpha /^{\circ}$ & & - & $103.149(17)$ \\
\hline$\beta /{ }^{\circ}$ & 97.208(5) & $116.575(2)$ & $113.233(9)$ \\
\hline$\gamma /^{\circ}$ & & - & $100.144(14)$ \\
\hline$V / \mathrm{A}^{3}$ & $2169.7(12)$ & $8892(2)$ & $2666(6)$ \\
\hline$\rho_{\text {calcd }}\left(\mathrm{g} \mathrm{cm}^{-3}\right)$ & 1.838 & 1.407 & 1.506 \\
\hline$T / K$ & 190.15 & 190 & 190 \\
\hline Z & 4 & 4 & 1 \\
\hline$\mu / \mathrm{mm}^{-1}$ & 2.044 & 1.714 & 2.028 \\
\hline Crystal size (mm) & $0.45 \times 0.15 \times 0.15$ & $0.2 \times 0.2 \times 0.1$ & $0.2 \times 0.2 \times 0.1$ \\
\hline \multicolumn{4}{|c|}{ Reflections collected: } \\
\hline Total & 15,704 & 66,906 & 9178 \\
\hline Unique & 3838 & 15737 & 9178 \\
\hline$R_{\text {int }}$ & 0.0676 & 0.0795 & 0.0873 \\
\hline Final $R_{1}, w R_{2}$ & $0.0630,0.1710$ & $0.0679,0.1817$ & $0.0998,0.2402$ \\
\hline
\end{tabular}

\section{Conclusions}

We reported the coordination versality of two double Schiff base ligands $\mathrm{H}_{3} \mathrm{~L}$ (potentially pentadentate $\left(\mathrm{N}_{2} \mathrm{O}_{3}\right)$ tri-anionic) and $\mathrm{H}_{5} \mathrm{~L} 1$ (potentially heptadentate $\left(\mathrm{N}_{2} \mathrm{O}_{5}\right)$ penta-anionic) with a high degree of conformational flexibility, having one or two ethanoate hydroxy groups in the side arms and a potential to coordinate in a convergent and a divergent fashion with $\mathrm{Cu}$ (II) ions. Based on the reaction conditions, the nature of the anion, and the stereochemical requirements of the metal, these ligands were shown to exhibit diverse coordination versatility. In complex $1, \mathrm{H}_{3} \mathrm{~L}$ acts as tetradentate $\left(\mathrm{N}_{2} \mathrm{O}_{2}\right)$ dianionic ligand $\left(\mathrm{HL}^{2-}\right)$, whereas in 2 , it acts as a pentadentate $\left(\mathrm{N}_{2} \mathrm{O}_{3}\right)$ tri-anionic $\left(\mathrm{L}^{3-}\right)$ ligand, holding two $\mathrm{Cu}(\mathrm{II})$ ions in close proximity for magnetic exchange interaction. Reactions of copper(II) ions with $\mathrm{H}_{5} \mathrm{~L} 1$ under varied conditions resulted in the formation of dinuclear (3), polynuclear (4), heptanuclear (5), and decanuclear (6) complexes, depending upon the anions. This clearly demonstrated the significant effect of the nature of an anion on the nuclearity of the complex produced. In dinuclear complex 3 and polynuclear complex 4, which grew into very fascinating 3D-network structures through H-bonding, 
and in decanuclear complex $6, \mathrm{H}_{5} \mathrm{~L} 1$ acted as a pentadentate $\left(\mathrm{N}_{2} \mathrm{O}_{3}\right)$ dianionic dinculeating ligand $\left(\mathrm{H}_{3} \mathrm{~L}^{2-}\right)$. In complex 6 , ethanolic $(\mathrm{OH})$ groups in the side arms of the ligand remained protonated and uncoordinated, and were involved in symmetrical $\mathrm{H}$-bonding, generating $1 \mathrm{D}$-single chains of decanuclear cationic $\left[\mathrm{Cu}_{10}\left(\mathrm{H}_{3} \mathrm{~L}^{2-}\right)_{4}\left(\mu_{3}-\mathrm{O}\right)_{2}(\mu-\mathrm{OH})_{2}\left(\mu_{3}-1,1,3-\mathrm{C}_{6} \mathrm{H}_{5} \mathrm{CO}_{2}\right)_{4}\right]^{2+}$, units. In heptanuclear complex 5, $\mathrm{H}_{5} \mathrm{~L} 1$ behaved as a hexadentate $\left(\mathrm{N}_{2} \mathrm{O}_{4}\right)$ dianionic ligand $\left(\mathrm{H}_{3} \mathrm{L1}^{2-}\right)$. In complex 5, benzoate ions exhibited four different types of coordination modes which, in our opinion, constitutes a novel discovery. The magnetic coupling in complexes 1, 3, and 5 was dominated

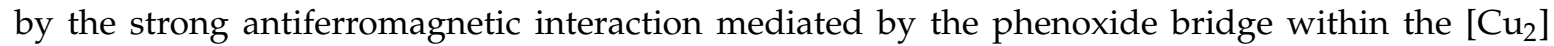
moieties with coupling constants ranging from -177 to $-278 \mathrm{~cm}^{-1}$ (in the $H=-J\left(S_{1} S_{2}\right)$ convention). Magneto-structural relationships in all doubly bridged $\left[\mathrm{Cu}_{2}(\mathrm{OPh})\left(\mu-1,1-\mathrm{N}_{3}\right)\right]$ core were examined. The effect of $\mu$-phenolato and $\mu$-azido bridge, and intermetallic distance (d) on the magnitude of coupling constant were investigated.

Supplementary Materials: The following are available online, Selected interatomic distances and angles are listed in the Tables S1-S6 and UV-vis spectroscopy. Figure S1 (Perspective view of crystal packing of 3 along the ab axis, showing the formation of a 2D-sheet structure). Figure S2 (Perspective view of a portion of 1D-single chain in 4 along the b-axis). Powder XRD patterns for 1, 3 and 5 in Figures S3-S5. Combined Checkcif report and combined crystallographic data file.

Author Contributions: Conceptualization, S.S.T. and methodology, S.S.T.; S.D.B.; formal analysis, S.S.T.; S.D.B.; investigation, N.P.; E.C.W.; R.T.; L.K.T.; S.D.B.; S.S.T.; resources, X.X.; data curation, S.S.T.; S.D.B.; writing一original draft preparation, S.S.T.; writing-review and editing, S.S.T.; S.D.B.; visualization, S.S.T.; S.D.B.; supervision, S.S.T.; S.D.B.; project administration, S.S.T.; funding acquisition, S.S.T. All authors have read and agreed to the published version of the manuscript.

Funding: This research received no external funding.

Acknowledgments: S.S.T. wants to thank Kent State University Salem Campus for financial support and Department of Chemistry and Biochemistry, Kent Campus for laboratory facilities and Mahinda Gangoda and Bishnu Pant for assistance with spectroscopic and analytical studies.

Conflicts of Interest: The authors declare no conflict of interest.

\section{References}

1. Uhlenheuer, D.A.; Petkau, K.; Brunsreld, L. Combining supramolecular chemistry with biology. Chem. Soc. Rev. 2010, 39, 2817-2826. [CrossRef] [PubMed]

2. Davis, J.T.; Spada, G.P. Supramolecular architectures generated by self-assembly of guanosine derivatives. Chem. Soc. Rev. 2007, 36, 296-313. [CrossRef] [PubMed]

3. Younjin, M.; Mustafa, A.; Kai, K.; Yuval, G.; Jacob, I. The role of interparticle and external forces in nanoparticle assembly. Nat. Mater. 2008, 7, 527-538.

4. Lehn, J.-M. Supramolecular Chemistry—Scope and perspectives molecules, supermolecules, and molecular devices (Nobel Lecture). Angew. Chem. Int. Ed. 1988, 27, 89-112. [CrossRef]

5. Lohmeijer, B.G.G.; Schubert, U.S. Supramolecular engineering with macromolecules: An alternative concept for block copolymers. Angew. Chem. Int. Ed. 2002, 41, 3825-3829. [CrossRef]

6. Lehn, J.-M. Supramolecular Chemistry: Concepts and Perspectives; VCH: Weihneim, Germany, 1995.

7. Stupp, S.I.; Palmer, L.C. Supramolecular chemistry and self-Assembly in organic materials design. Chem. Mater. 2014, 26, 507-518. [CrossRef]

8. Nicolaou, K.C.; Vourloumis, D.; Winssinger, N.; Baran, P.S. The art and science of total synthesis at the dawn of the twenty-first century. Angew. Chem. Int. Ed. 2000, 39, 44-122. [CrossRef]

9. He, Z.; Jiang, W.; Schalley, C.A. Integrative self-sorting: A versatile strategy for the construction of complex supramolecular architecture. Chem. Soc. Rev. 2015, 44, 779-789. [CrossRef]

10. Stang, P.J.; Olenyuk, B. Self-Assembly, symmetry, and molecular architecture: Coordination as the motif in the rational design of supramolecular metallacyclic polygons and polyhedra. Acc. Chem. Res. 1997, 30, 502-518. [CrossRef]

11. Glotzer, S.C. Some assembly required. Science 2004, 306, 419-420. [CrossRef]

12. Boles, M.A.; Engel, M.; Talapin, D.V. Self-assembly of colloidal nanocrystals: From intricate structures to functional materials. Chem. Rev. 2016, 116, 11220-11289. [CrossRef] 
13. Cook, T.R.; Zheng, Y.-R.; Stang, P.J. Metal-organic frameworks and self-assembled supramolecular coordination complexes: Comparing and contrasting the design, synthesis, and functionality of metal-organic materials. Chem. Rev. 2013, 113, 734-777. [CrossRef] [PubMed]

14. Tanaka, S.; Tsurugi, H.; Mashima, K. Supramolecular assemblies of multi-nuclear transition metal complexes: Synthesis and redox properties. Coord. Chem. Rev. 2014, 265, 38-51. [CrossRef]

15. Dalgarno, S.J.; Power, N.P.; Atwood, J.L. Metallo-supramolecular capsules. Coord. Chem. Rev. 2008, 252, 825-841. [CrossRef]

16. Koshevoy, I.O.; Koskinen, L.; Haukka, M.; Tunik, S.P.; Serdobintsev, P.Y.; Melnikov, A.S.; Pakkanen, T.A. Self-assembly of supramolecular luminescent AuI-CuI complexes: "Wrapping" an Au6Cu6 cluster in a [Au3(diphosphine)3]3+ "Belt". Angew. Chem. Int. Ed. 2008, 47, 3942-3945. [CrossRef]

17. Fujita, M. Molecular Self-Assembly Organic Versus Inorganic Approaches; Springer: Berlin/Heidelberg, Germany, 2003.

18. Caulder, D.L.; Powers, R.E.; Parac, T.N.; Raymond, K.N. The Self-assembly of a predesigned tetrahedral M4L6 supramolecular cluster. Angew. Chem. Int. Ed. 1998, 37, 1840-1843. [CrossRef]

19. Zheng, Z. Ligand-controlled self-assembly of polynuclear lanthanide-oxo/hydroxo complexes: From synthetic serendipity to rational supramolecular design. Chem. Commun. 2001, 24, 2521-2529. [CrossRef]

20. Johnson, D.W.; Xu, J.; Saalfrank, R.W.; Raymond, K.N. Self-Assembly of a three-dimensional [Ga6(L2)6] metal-ligand "Cylinder". Anew. Chem. Int. Ed. 1999, 38, 2882-2885. [CrossRef]

21. Saalfrank, R.W.; Glaser, H.; Demleitner, B.; Hampel, F.; Chowdhary, M.M.; Schunemann, V.; Trautwein, A.X.; Vaughan, G.B.M.; Yeh, R.; Davis, A.V.; et al. Self-assembly of tetrahedral and trigonal antiprismatic clusters [Fe4(L4)4] and [Fe6(L5)6] on the basis of trigonal tris-Bidentate chelators. Chem. Eur. J. 2002, 8, 493-497. [CrossRef]

22. Diederich, F.; Stang, P.J. Templated Organic Synthesis; Wiley-VCH: Weinheim, Germany, 2000.

23. Tandon, S.S.; Bunge, S.D.; Toth, S.A.; Sanchiz, J.; Thompson, L.K.; Shelley, J.T. Antiferromagnetically coupled dimeric dodecacopper supramolecular architectures of macrocyclic ligands with a symmetrical $\mu_{6}-\mathrm{BO}_{3}{ }^{3-}$ central moiety. Inorg. Chem. 2015, 54, 6873-6884. [CrossRef]

24. McKee, V.; Tandon, S.S. X-ray crystal structure and some properties of a tetranuclear, mixed-valence manganese complex of a macrocyclic ligand. J. Chem. Soc. Chem. Commun. 1988, 19, 1334-1336. [CrossRef]

25. McKee, V.; Tandon, S.S. The X-ray crystal structure and some properties of a planar tetracopper(II) macrocyclic complex containing a $\mu 4$-hydroxo bridge. J. Chem. Soc. Chem. Commun. 1988, 385-387. [CrossRef]

26. McKee, V.; Tandon, S.S. An octacopper(II) complex with . $\mu .5$-oxo, and tripod-like perchlorate ligands; formation and x-ray structure of the $\left[\mathrm{Cu}_{4}(\mathrm{~L}) \mathrm{O}\left(\mathrm{ClO}_{4}\right)\right]_{2}\left(\mathrm{ClO}_{4}\right)_{2} \cdot 2 \mathrm{H}_{2} \mathrm{O}$ dimer. Inorg. Chem. 1989, 28, 2901-2902. [CrossRef]

27. Tandon, S.S.; McKee, V. Lead(II) and barium(II) complexes of a potentially octadentate macrocyclic ligand $\left(\mathrm{H}_{4} \mathrm{~L}\right)$, capable of providing endogenous alkoxy and phenoxy bridges. The x-ray crystal structures of $\left[\mathrm{Pb}\left(\mathrm{H}_{4} \mathrm{~L}\right)\right]\left(\mathrm{ClO}_{4}\right)_{2},\left[\mathrm{~Pb}_{2}\left(\mathrm{H}_{2} \mathrm{~L}\right)\right]\left(\mathrm{ClO}_{4}\right)_{2}$ and $\left[\mathrm{H}_{6} \mathrm{~L}\left(\mathrm{H}_{2} \mathrm{O}\right)_{2}\right]\left(\mathrm{ClO}_{4}\right)_{2}$. J. Chem. Soc. Dalton Trans. 1989, 19-24. [CrossRef]

28. Downard, J.; McKee, V.; Tandon, S.S. Binuclear manganese(II) and nickel(II) complexes of a potentially octadentate macrocyclic ligand $\left(\mathrm{H}_{4} \mathrm{~L}\right)$, capable of providing endogenous alkoxy and phenoxy bridges. The x-ray crystal structures of $\left[\mathrm{Mn}_{2}\left(\mathrm{H}_{2} \mathrm{~L}\right)\left(\mathrm{CH}_{3} \mathrm{COO}\right)_{2}\right] \cdot \mathrm{CH}_{3} \mathrm{OH}$ and $\left[\mathrm{Ni}_{2}\left(\mathrm{H}_{2} \mathrm{~L}\right) \mathrm{Cl}_{2}\left(\mathrm{H}_{2} \mathrm{O}\right)_{2}\right]$. Inorg. Chim. Acta 1990, 173, 181-190. [CrossRef]

29. McKee, V.; Tandon, S.S. Synthesis and characterization of a series of tetra- and octa-copper(11) complexes with macrocyclic ligands. J. Chem. Soc. Dalton Trans. 1991, 221-230. [CrossRef]

30. Tandon, S.S.; Thompson, L.K.; Bridson, J.N.; McKee, V.; Downard, A.J. Dinuclear copper(II) and polymeric tetranuclear copper(II) and copper(II)-copper(I) complexes of macrocyclic ligands capable of forming endogenous alkoxide and phenoxide bridges. Structural, magnetic, and electrochemical studies. Inorg. Chem. 1992, 31, 4635-4642. [CrossRef]

31. Tandon, S.S.; Thompson, L.K.; Bridson, J.N. A Novel Antiferromagnetically coupled, dimeric, dodecanuclear copper(I1) complex involving two macrocyclic ligands each with a 'benzene-like' arrangement of six copper centres. J. Chem. Soc. Chem. Commun. 1992, 911-913. [CrossRef] 
32. Tandon, S.S.; Thompson, L.K.; Bridson, J.N.; Bubenik, M. Synthetic, structural and magnetic properties of mononuclear, dinuclear and tetranuclear copper(II) complexes of a 17-membered macrocyclic ligand (HM3), capable of forming endogenous phenoxide and pyridazino bridges. X-ray crystal structure of $\left[\mathrm{Cu}_{2}(\mathrm{M} 3)\left(\mu_{2}-\mathrm{OMe}\right)\left(\mathrm{NO}_{3}\right)_{2}\right],\left[\mathrm{Cu}_{4}(\mathrm{M} 3)_{2}\left(\mu_{3}-\mathrm{OMe}\right)_{2}\left(\mu_{2}-\mathrm{Cl}_{2} \mathrm{Cl}_{2}\right],\left[\mathrm{Cu}_{4}(\mathrm{M} 3)_{2}\left(\mu_{3}-\mathrm{OEt}\right)_{2}\left(\mu_{2}-\mathrm{N}_{3}\right)_{2}\left(\mathrm{~N}_{3}\right)_{2}\right] .(\mathrm{MeOH})\right.$, $\left[\mathrm{Cu}_{4}(\mathrm{M} 3)\left(\mu_{3}-\mathrm{Ome}\right)_{2}(\mathrm{NCS})_{4}\right](\mathrm{DMF})$ and $\left[\mathrm{Cu}(\mathrm{HM} 3)(\mathrm{NCS})_{2}\right]$. Inorg. Chem. 1993, 32, 4621-4631.

33. Chen, L.; Thompson, L.K.; Tandon, S.S.; Bridson, J.N. Synthetic, structural, and spectroscopic studies on copper(II), copper(I), and silver(I) complexes of a series of pyridazinophane and phthalazinophane macrocycles. Unusual extended metallocyclic structures. Inorg. Chem. 1993, 32, 4063-4068. [CrossRef]

34. Tandon, S.S.; Thompson, L.K.; Bridson, J.N. Dinuclear copper(II) and mixed-valence copper(II)-copper(I) complexes of a 34-membered macrocyclic ligands $\left(\mathrm{H}_{2} \mathrm{M} 1, \mathrm{H}_{2} \mathrm{M} 2\right)$ capable of forming endogenous phenolate and pyridazino bridges. X-ray crystal structures of the dinuclear copper(II) complexes $\left[\mathrm{Cu}_{2} \mathrm{M} 1\right]\left[\mathrm{BF}_{4}\right]_{2} \cdot \mathrm{H}_{2} \mathrm{O}$ and $\left[\mathrm{Cu}_{2} \mathrm{M} 2\right]\left[\mathrm{BF}_{4}\right]_{2} \cdot \mathrm{CH} 3 \mathrm{OH}$, which exhibit a remarkable ligand twist. Inorg. Chem. 1993, 32, 32-39.

35. Tandon, S.S.; Thompson, L.K.; Bridson, J.N.; Benelli, C. Hexanuclear and dodecanuclear macrocyclic copper(II) and nickel(II) complexes with almost planar "benzene-like" metal arrays. Inorg. Chem. 1995, 34, 5507-5515. [CrossRef]

36. Thompson, L.K.; Tandon, S.S.; Bridson, J.N.; Park, M.K. Magnetostructural Correlations in Bis( $\mu 2$-phenoxide)-Bridged Macrocyclic Dinuclear Copper(II) Complexes. Influence of Electron-Withdrawing Substituents on Exchange Coupling. Inorg. Chem. 1996, 35, 3117-3125. [CrossRef] [PubMed]

37. McCrea, J.; McKee, V.; Metcalfe, T.; Tandon, S.S.; Wikaira, J. Geometric control of redox level in tetranuclear manganese and cobalt systems. Inorg. Chim. Acta 2000, 297, 220-230. [CrossRef]

38. Tandon, S.S.; Bunge, S.D.; Thompson, L.K. A tetradecanuclear copper dimeric macrocyclic complex with a body-centred heptanuclear core-structure and magnetism. Chem. Commun. 2007, 798-800. [CrossRef]

39. Tandon, S.S.; Bunge, S.D.; Patel, N.; Thompson, L.K. The synthesis, structure, and magnetic properties of a novel copper(II) cluster with H-bonding directed 3D-structure comprised of interconnected double-stranded ladders. Inorg. Chem. Commun. 2009, 12, 1077-1080. [CrossRef]

40. Tandon, S.S.; Bunge, S.D.; Rakosi, R.; Xu, Z.; Thompson, L.K. Self-assembly of mixed-valence Co(ii/iii) and $\mathrm{Ni}$ (ii) clusters: Azide-bridged 1D single chain coordination polymers comprised of tetranuclear units, tetranuclear Co(ii/iii) complexes, ferromagnetically coupled azide-bridged tetranuclear, and hexanuclear Ni(ii) complexes: Synthesis, structural, and magnetic properties. Dalton Trans. 2009, 6536-6551. [CrossRef]

41. Tandon, S.S.; Bunge, S.D.; Motry, D.; Costa, J.S.; Aromí, G.; Reedijk, J.; Thompson, L.K. Copper coordination polymers based on single-chain or sheet structures involving dinuclear and tetranuclear copper(II) units: Synthesis, structures, and magnetostructural correlations. Inorg. Chem. 2009, 48, 4873-4881. [CrossRef]

42. Tandon, S.S.; Bunge, S.D.; Sanchiz, J.; Thompson, L.K. Structures and magnetic properties of an antiferromagnetically coupled polymeric copper(II) complex and ferromagnetically coupled hexanuclear nickel(II) clusters. Inorg. Chem. 2012, 51, 3270-3282. [CrossRef]

43. Tandon, S.S.; Bunge, S.D.; Patel, N.; Sanchiz, J. H-bonding directed formation of 1D-single chains, 2D-sheets, and 3D structures in magnetically coupled tetranuclear nickel(II) complexes with incomplete double cubane core. Polyhedron 2017, 123, 361-375. [CrossRef]

44. Wilkinson, M.J.; Van Leeuwen, P.W.; Reek, J.N. New directions in supramolecular transition metal catalysis. Org. Biomol. Chem. 2005, 3, 2371-2383. [CrossRef]

45. Van Leeuwen, P.W.N.M. Homogeneous Catalysis; Kluwer Academic Publishers: Dordrecht, The Netherlands, 2004.

46. Funabiki, T. Catalysis by Metal Complexes; Springer-International Publisher Science, Technology, Medicine: New York, NY, USA, 1997; Volume 19.

47. Sivasubramaniam, V.K.; Ganesan, M.; Rajagopal, S.; Ramaraj, R.B. Iron(III)-salen complexes as enzyme models: mechanistic study of oxo(salen)iron complexes oxygenation of organic sulfides. J. Org. Chem. 2002, 67, 1506-1514. [CrossRef] [PubMed]

48. Rizzarelli, E.; Vecchio, G. Metal complexes of functionalized cyclodextrins as enzyme models and chiral receptors. Coord. Chem. Rev. 1999, 188, 343-364. [CrossRef]

49. Van den Benken, E.K.; Feringu, B.L. Bimetallic catalysis by late transition metal complexes. Tetrahedron 1998, 54, 12985-13011. [CrossRef]

50. Karlin, K.D. Progress in Inorganic Chemistry; Wiley: New York, NY, USA, 2007; Volume 41.

51. Plass, W. Structural variety and magnetic properties of polynuclear assemblies based on 2-aminoglucose and tritopic triaminoguanidine ligands. Coord. Chem. Rev. 2009, 253, 2286-2295. [CrossRef] 
52. Burkhard, A.; Spielberg, E.T.; Simon, S.; Gorls, H.; Buchholz, A.; Plass, W. Hydrogen bonds as structural directive towards unusual polynuclear complexes: Synthesis, structure, and magnetic properties of copper(II) and nickel(II) complexes with a 2-aminoglucose ligand. Chem. Eur. J. 2009, 15, 1261-1271. [CrossRef]

53. Ribas, R.; Escuer, A.; Monfort, M.; Vicente, R.; Cortes, R.; Lezama, L.; Rojo, T. Polynuclear Ni ${ }^{\mathrm{II}}$ and $\mathrm{Mn}^{\mathrm{II}}$ azido bridging complexes. Structural trends and magnetic behavior. Coord. Chem. Rev. 1999, 193-195, 1027-1068. [CrossRef]

54. Dul, M.C.; Pardo, E.; Lescouëzec, R.; Journaux, Y.; Ferrando-Soria, J.; Ruiz-García, R.; Cano, J.; Julve, M.; Lloret, F.; Cangussu, D.; et al. Supramolecular coordination chemistry of aromatic polyoxalamide ligands: A metallosupramolecular approach toward functional magnetic materials. Coord. Chem. Rev. 2010, 254, 22. [CrossRef]

55. Christou, G.; Gatteschi, D.; Hendrickson, D.N.; Sessoli, R. Single-molecule magnets. MRS Bull. 2000, 25, 66-71. [CrossRef]

56. Miller, J.S.; Drillon, M. Magnetism: Molecules to Materials; Wiley: Weinheim, Germany, 2001.

57. Miller, J.S.; Epstein, A. Organic and organometallic molecular magnetic materials—Designer magnets. Angew. Chem. Int. Ed. 1994, 33, 385-415. [CrossRef]

58. Wernsdorfer, W.; Sessoli, R. Quantum phase interference and parity effects in magnetic molecular clusters. Science 1999, 284, 133-135. [CrossRef] [PubMed]

59. Bogani, L.; Wernsdorfer, W. Molecular spintronics using single-molecule magnets. Nat. Mater. 2008, 7, 179-186. [CrossRef]

60. Caneschi, A.; Gatteschi, D.; Lalioti, N.; Sangregorio, C.; Sessoli, R.; Ventiru, G.; Vendigni, A.; Rettori, A.; Pini, M.G.; Novak, M.A. Cobalt(II)-nitronyl nitroxide chains as molecular magnetic nanowires. Angew. Chem. Int. Ed. 2001, 40, 1760-1763. [CrossRef]

61. Gatteschi, D.; Sessoli, R. Quantum tunneling of magnetization and related phenomena in molecular materials. Angew. Chem. Int. Ed. 2003, 42, 268-297. [CrossRef]

62. Thomas, L.; Lionti, F.; Ballou, R.; Gatteschi, D.; Sessoli, R.; Barbara, B. Macroscopic quantum tunnelling of magnetization in a single crystal of nanomagnets. Nature 1996, 383, 145-147. [CrossRef]

63. Milios, C.J.; Vinslava, A.; Wernsdorfer, W.; Moggach, S.; Parsons, S.; Perlepes, S.P.; Christou, G.; Brechin, E.K. A Record anisotropy barrier for a single-molecule magnet. J. Am. Chem. Soc. 2007, 129, 2754-2755. [CrossRef]

64. Timco, G.A.; Faust, T.B.; Tuna, F.; Winpenny, R.E.P. Linking heterometallic rings for quantum information processing and amusement. Chem. Soc. Rev. 2011, 40, 3067-3075. [CrossRef]

65. Santini, P.; Carretta, S.; Troiani, F.; Amoretti, G. Molecular nanomagnets as quantum simulators. Phys. Rev. Lett. 2011, 107, 230502. [CrossRef]

66. Timco, G.A.; McInnes, E.J.L.; Winpenny, R.E.P. Physical studies of heterometallic rings: An ideal system for studying magnetically-coupled systems. Chem. Soc. Rev. 2013, 42, 1796-1806. [CrossRef]

67. Kahn, O. Molecular Magnetism; VCH: New York, NY, USA, 1993; p. 131.

68. Murrie, M. Cobalt(II) single-molecule magnets. Chem. Soc. Rev. 2010, 39, 1986-1995. [CrossRef]

69. Aromi, G.; Brechin, E.K. Synthesis of 3d metallic single-molecule magnets. In Single-Molecule Magnets and Related Phenomena; Structure and Bonding Series; Winpenny, R., Ed.; Springer: Berlin/Heidelberg, Germany, 2006; Volume 122.

70. Thompson, L.K. Polynuclear coordination complexes-From dinuclear to nonanuclear and beyond. Coord. Chem. Rev. 2002, 233-234, 193-206. [CrossRef]

71. Thompson, L.K.; Dawe, L.N. Magnetic properties of transition metal (Mn(II), Mn(III), Ni(II), Cu(II)) and lanthanide (Gd(III), Dy(III), Tb(III), Eu(III), Ho(III), $\mathrm{Yb}(\mathrm{III})$ ) clusters and [nxn] grids: Isotropic exchange and SMM behaviour. Coord. Chem. Rev. 2015, 289-290, 13-31. [CrossRef]

72. Turnbull, M.M.; Sugimoto, T.; Thompson, L.K. Molecule-Based Magnetic Materials_Theory, Techniques, and Applications; ACS: Washington, DC, USA, 1996; Volume 644.

73. Ferguson, A.; Lawrence, J.; Parkin, A.; Sanchez-Benitez, J.; Kamenev, K.V.; Brechin, E.K.; Wernsdorfer, W.; Hill, S.; Murrie, M. Synthesis and characterisation of a $\mathrm{Ni}_{4}$ single-molecule magnet with $S_{4}$ symmetry. Dalton Trans. 2008, 6409-6414. [CrossRef] [PubMed]

74. Ritchie, C.; Ferguson, A.; Nojiri, H.; Miras, H.N.; Song, Y.-F.; Long, D.-L.; Burkholder, E.; Murrie, M.; Kogerler, P.; Brechin, E.K.; et al. Polyoxometalate-mediated self-assembly of single-molecule magnets: $\left\{\left[\mathrm{XW}_{9} \mathrm{O}_{34}\right]_{2}\left[\mathrm{Mn}^{\mathrm{III}}{ }_{4} \mathrm{Mn}_{2}{ }_{2} \mathrm{O}_{4}\left(\mathrm{H}_{2} \mathrm{O}\right)_{4}\right]\right\}^{12}$. Angew. Chem. Int. Ed. 2008, 47, 5609-5612. [CrossRef] [PubMed] 
75. Milios, C.J.; Vinslava, A.; Wood, P.A.; Parsons, S.; Wernsdorfer, W.; Christou, G.; Perlepes, S.P.; Brechin, E.K. A Single-molecule magnet with a "Twist". J. Am. Chem. Soc. 2007, 129, 8-9. [CrossRef]

76. Stamatatos, T.C.; Abboud, K.A.; Wernsdorfer, W.; Christou, G. "Spin Tweaking" of a high-spin molecule: An Mn25 single-molecule magnet with an $\mathrm{S}=61 / 2$ ground state. Angew. Chem. Int. Ed. 2007, 46, 884-888. [CrossRef] [PubMed]

77. Milios, C.J.; Inglis, R.; Vinslava, A.; Bagai, R.; Wernsdorfer, W.; Parsons, S.; Perlepes, S.P.; Christou, G.; Brechin, E.K. Toward a magnetostructural correlation for a family of Mn6 SMMs. J. Am. Chem. Soc. 2007, 129, 12505-12511. [CrossRef]

78. Murugesu, M.; Habrych, M.; Wernsdorfer, W.; Abboud, K.A.; Christou, G. Single-molecule magnets: A Mn25 complex with a record $\mathrm{S}=51 / 2$ spin for a molecular species. J. Am. Chem. Soc. 2004, 126, 4766-4767. [CrossRef]

79. Soler, M.; Wernsdorfer, W.; Folting, K.; Pink, M.; Christou, G. Single-molecule magnets: A large Mn30 molecular nanomagnet exhibiting quantum tunneling of magnetization. J. Am. Chem. Soc. 2004, 126, 2156-2165. [CrossRef]

80. Aliaga-Alcalde, N.; Edwards, R.S.; Hill, S.O.; Wernsdorfer, W.; Foltin, K.; Christou, G. Single-molecule magnets: Preparation and properties of low symmetry $\left[\mathrm{Mn}_{4} \mathrm{O}_{3}\left(\mathrm{O}_{2} \mathrm{CPh}-\mathrm{R}\right)_{4}(\mathrm{dbm})_{3}\right]$ complexes with S=9/2. J. Am. Chem. Soc. 2004, 126, 12503-12516. [CrossRef]

81. Bagai, R.; Wernsdorfer, W.; Abboud, K.A.; Christou, G. Exchange-biased dimers of single-molecule magnets in oFF and oN states. J. Am. Chem. Soc. 2007, 129, 12918-12919. [CrossRef] [PubMed]

82. Coulon, C.; Miyasaki, H.; Clerac, R. Single-chain magnets:Theoretical approach and experimental systems. Struct. Bond. 2006, 122, 163.

83. Coulon, C.; Clerac, R.; Lecren, L.; Wernsdorfer, W.; Miyasaka, H. Glauber dynamics in a single-chain magnet: From theory to real systems. Phys. Rev. B 2004, 69, 132408. [CrossRef]

84. Yang, E.C.; Hendrickson, D.N.; Wernsdorfer, W.; Nakano, M.; Zakharov, L.N.; Sommer, R.D.; Rheingold, A.L.; Ledezma-Gairaud, M.; Christou, G. Cobalt single-molecule magnet. J. Appl. Phys. 2002, 91, 7382-7384. [CrossRef]

85. Clerac, R.; Miyasaka, H.; Yamashita, M.; Coulon, C. Evidence for single-chain magnet behavior in a Mn ${ }^{\mathrm{III}}-\mathrm{Ni}^{\mathrm{II}}$ chain designed with high spin magnetic units: A route to high temperature metastable magnets. J. Am. Chem. Soc. 2002, 124, 12837-12844. [CrossRef]

86. Brechin, E.K.; Boskovic, C.; Wernsdorfer, W.; Yoo, J.; Yamaguchi, A.; Sanudo, E.C.; Concolino, Y.R.; Rheingold, A.L.; Ishimoto, H.; Hendrickson, D.N.; et al. Quantum tunneling of magnetization in a new $\left[\mathrm{Mn}_{18}\right]^{2+}$ Single-molecule magnet with $S=13$. J. Am. Chem. Soc. 2002, 124, 9710-9711. [CrossRef] [PubMed]

87. Friedman, J.R.; Sarachik, M.P.; Tejada, J.; Maciejewski, J.; Ziolo, R. Steps in the hysteresis loops of a high-spin molecule. J. Appl. Phys. 1996, 79, 6031-6033. [CrossRef]

88. Friedman, J.R.; Sarachik, M.P.; Tejada, J.; Ziolo, R. Macroscopic measurement of resonant magnetization tunneling in high-spin molecules. Phys. Rev. Lett. 1996, 76, 3830-3833. [CrossRef]

89. Massoud, S.S.; Mautner, F.A.; Vicente, R.; Gallo, A.A.; Ducasse, E. Dinuclear and polynuclear bridged azido-nickel(II) complexes: Synthesis, structure determination, and magnetic properties. Eur. J. Inorg. Chem. 2007, 2007, 1091-1102. [CrossRef]

90. Escuer, A.; Aromi, G. Azide as a bridging ligand and magnetic coupler in transition metal clusters. Eur. J. Inorg. Chem. 2006, 2006, 4721-4736. [CrossRef]

91. Ferbinteanu, M.; Miyasaka, H.; Wernsdorfer, W.; Nakata, K.; Sugiura, K.; Yamashita, M.; Coulon, C.; Clerac, R. Single-chain magnet $\left(\mathrm{NEt}_{4}\right)\left[\mathrm{Mn}_{2}(5-\mathrm{MeOsalen})_{2} \mathrm{Fe}(\mathrm{CN})_{6}\right]$ made of $\mathrm{Mn}^{\mathrm{III}}-\mathrm{Fe}^{\mathrm{III}}-\mathrm{Mn}^{\mathrm{III}}$ trinuclear single-molecule magnet with an $S_{\mathrm{T}}=9 / 2$ spin ground state. J. Am. Chem. Soc. 2005, 127, 3090-3099. [CrossRef]

92. Tasiopoulos, A.J.; Vinslava, A.; Wernsdorfer, W.; Abboud, K.A.; Christou, G. Giant single-molecule magnets: A $\{$ Mn84\} torus and its supramolecular nanotubes. Angew. Chem. Int. Ed. 2004, 43, 2117-2121. [CrossRef] [PubMed]

93. Chakov, N.E.; Wernsdorfer, W.; Abboud, K.A.; Christou, G. Mixed-valence $\mathrm{Mn}^{\mathrm{III}} \mathrm{Mn}^{\mathrm{IV}}$ clusters $\left[\mathrm{Mn}_{7} \mathrm{O}_{8}\left(\mathrm{O}_{2} \mathrm{SePh}\right)_{8}\left(\mathrm{O}_{2} \mathrm{CMe}\right)\left(\mathrm{H}_{2} \mathrm{O}\right)\right]$ and $\left[\mathrm{Mn}_{7} \mathrm{O}_{8}\left(\mathrm{O}_{2} \mathrm{SePh}\right)_{9}\left(\mathrm{H}_{2} \mathrm{O}\right)\right]$ : Single-chain magnets exhibiting quantum tunneling of magnetization. Inorg. Chem. 2004, 43, 5919-5930. [CrossRef] [PubMed]

94. Chakraborty, A.; Rao, L.S.; Manna, A.K.; Pati, S.K.; Ribas, J.; Maji, T.K. Discrete dinuclear complex to extended 2D compound in a $\mathrm{Cu}$-azido system by controlling coligand stoichiometry: Synthesis and magneto-structural correlations. Dalton Trans. 2013, 42, 10707-10714. [CrossRef] [PubMed] 
95. Nanda, P.K.; Aromi, G.; Ray, D. Tetranuclear Cu(ii) complex supported by a central $\mu_{4}-1,1,3,3$ azide bridge. Chem. Commun. 2006, 3181-3183. [CrossRef]

96. Demeshko, S.; Leibeling, G.; Maringgele, W.; Meyer, F.; Mennerich, C.; Klauss, H.H.; Pritzkow, H. Structural variety and magnetic properties of tetranuclear nickel(II) complexes with a central $\mu_{4}$-azide. Inorg. Chem. 2005, 44, 519-528. [CrossRef]

97. Meyer, F.; Demeshko, S.; Leibeling, G.; Kersting, B.; Kaifer, E.; Pritzkow, H. Structures and magnetic properties of tetranuclear Nickel(II) complexes with unusual $\mu_{3}-1,1,3$ Azido bridges. Chem. Eur. J. 2005, 11, 1518-1526. [CrossRef]

98. Boudalis, A.K.; Donnadieu, B.; Nastopoulos, V.; Clemente-Juan, J.M.; Mari, A.; Sanakis, Y.; Tuchagues, J.P.; Perlepes, S.P. A Nonanuclear. Iron(II) single-molecule magnet. Angew. Chem. Int. Ed. 2004, 43, 2266-2270. [CrossRef]

99. Meyer, F.; Kozlowski, H. Nickel. In Comprehensive Coordination Chemistry; McCleverty, J.A., Meyer, T.J., Eds.; Elsevier: Oxford, UK, 2004; pp. 247-276.

100. Ma, D.; Hikichi, S.; Akita, M.; Moro-oka, Y. An entry to half-sandwich complexes of first row transition metals $(\mathrm{Ni}, \mathrm{Co}, \mathrm{Mn})$ containing the Kläui tripodal ligand, $\mathrm{L}_{\mathrm{OMe}}$ : Synthesis and crystal structures of oligomeric, $\left[\mathrm{L}_{\mathrm{OMe}} \mathrm{M}(\mu-\mathrm{X})(\mathrm{L})\right] \mathrm{n}(\mathrm{n}=2,4)$, and monomeric complexes, $\mathrm{L}_{\mathrm{OMe}} \mathrm{M}(\mathrm{L} 2)(\mathrm{X})$. J. Chem. Soc. Dalton Trans. 2000, 7, 1123-1134. [CrossRef]

101. Thompson, L.K.; Tandon, S.S. Azide bridged dicopper and dinickel complexes: Structure and magnetism. Comm. Inorg. Chem. 1996, 18, 125-144. [CrossRef]

102. Halcrow, M.A.; Huffman, J.C.; Christou, G. A Nickel(II) Azide cubane: Characterization of the magnetic exchange interactions mediated by a triply bridging azide group bound end-on. Angew. Chem. Int. Ed. 1995, 34, 889-891. [CrossRef]

103. Halcrow, M.A.; Sun, J.S.; Huffman, J.C.; Christou, G. Structural and magnetic properties of $\left[\mathrm{Ni}_{4}\left(\mu_{3}-\mathrm{OMe}\right)_{4}(\mathrm{dbm})_{4}(\mathrm{MeOH})_{4}\right]$ and $\left[\mathrm{NI}_{4}\left(\eta^{1} \mu_{3}-\mathrm{N} 3\right)_{4}(\mathrm{dbm})_{4}(\mathrm{EtOH})_{4}\right]$. magnetostructural correlations for $\left[\mathrm{Ni}_{4} \mathrm{X}_{4}\right]^{4+}$ cubane complexes. Inorg. Chem. 1995, 34, 4167-4177. [CrossRef]

104. Charlot, M.F.; Kahn, O.; Chaillet, M.; Larrieu, C. Interaction between Copper(II) Ions through the azido bridge: Concept of spin polarization and ab initio calculations on model systems. J. Am. Chem. Soc. 1986, 108, 2574-2581. [CrossRef]

105. Zhang, W.X.; Ma, C.Q.; Wang, X.N.; Yu, Z.G.; Lin, Q.J.; Jiang, D.H. Synthesis and structure of tetranuclear copper(II) complex containing $\mu_{4}$-oxo bridge. Chin. J. Chem. 1995, 13, 497-503. [CrossRef]

106. Mukherjee, S.; Weyhermuller, T.; Bothe, E.; Wieghardt, K.; Chaudhuri, P. Single-atom O-bridged urea in a dinickel(II) complex together with $\mathrm{Ni}_{4}{ }_{4}, \mathrm{Cu}_{2}{ }_{2}$ and $\mathrm{Cu}_{4}{ }_{4}$ complexes of a pentadentate phenol-containing Schiff base with $(\mathrm{O}, \mathrm{N}, \mathrm{O}, \mathrm{N}, \mathrm{O})$-donor atom. Eur. J. Inorg. Chem. 2003, 2003, 863-875. [CrossRef]

107. Mukherjee, S.; Weyhermuller, T.; Bothe, E.; Chaudhuri, P. Structural, magnetochemical and electrochemical studies of dinuclear complexes containing the $\left[\mathrm{V}^{\mathrm{V}} \mathrm{O}_{2},\left[\mathrm{~V}^{\mathrm{IV}} \mathrm{O}\right] 2, \mathrm{Cr}_{2}{ }^{\mathrm{III}}, \mathrm{Mn}_{2}{ }^{\mathrm{III}}\right.$ and $\mathrm{Fe}_{2}{ }^{\mathrm{III}}$ cores of a potentially pentadentate phenol-containing ligand with $(\mathrm{O}, \mathrm{N}, \mathrm{O}, \mathrm{N}, \mathrm{O})$-donor atoms. Eur. J. Inorg. Chem. 2003, 2003, 1956-1965. [CrossRef]

108. Mandal, D.; Ray, D. Self-assembly of a face-shared partial double cubane supported by alkoxo terminal and bridging ligands. Inorg. Chem. Commun. 2007, 10, 1202-1205. [CrossRef]

109. Przyojski, J.A.; Myers, N.N.; Arman, H.D.; Prosvirin, A.; Dunbar, K.R.; Natarajan, M.; Krishnan, M.; Mohan, S.; Walmsley, J.A. Dinuclear and heptanuclear complexes of copper(II) with 7-azaindole ligand: Synthesis, characterization, magnetic properties, and biological activity. J. Inorg. Biochem. 2013, 127, 175-181. [CrossRef]

110. Ferrer, S.; Aznar, E.; Lloret, F.; Castiñeiras, A.; Liu-González, M.; Borrás, J. One-dimensional metal-organic framework with unprecedented heptanuclear copper units. Inorg. Chem. 2007, 46, 372-374. [CrossRef]

111. Majumder, S.; Sarkar, S.; Sasmal, S.; Sañudo, E.C.; Mohanta, S. Heterobridged dinuclear, tetranuclear, dinuclear-based 1-D, and heptanuclear-based 1-D complexes of copper(II) derived from a dinucleating ligand: Syntheses, structures, magnetochemistry, spectroscopy, and catecholase activity. Inorg. Chem. 2011, 50, 7540-7554. [CrossRef]

112. Gottschaldt, M.; Wegner, R.; Görls, H.; Jäger, E.-G.; Klemm, D. Synthesis and crystal structure of a heptanuclear and an octanuclear copper(II) complex derived from $\alpha$-D-glucofuranoses. Eur. J. Inorg. Chem. 2007, 2007, 3633-3638. [CrossRef] 
113. Xu, Y.; Xia, P.; Wang, X.; Wei, W.; Zhanga, F.; Hu, C. Positional disorder of Cu(ii) ions in a cluster: A novel heptanuclear $\mathrm{Cu}(\mathrm{ii})$ core supported by 4-bromo-3,5-dimethylpyrazolate. CrystEngComm 2011, 13, 2820-2823. [CrossRef]

114. Biswas, C.; Drew, M.G.B.; Ruiz, E.; Estrader, M.; Diaz, C.; Ghosh, A. Synthesis, crystal structure and magnetic properties of three unprecedented tri-nuclear and one very rare tetra-nuclear copper(II) Schiff-base complexes supported by mixed azido/phenoxo/nitrato or acetato bridges. Dalton Trans. 2010, 39, 7474-7484. [CrossRef] [PubMed]

115. Crawford, V.H.; Richardson, H.W.; Wasson, R.R.; Hodgson, D.J.; Hatfield, W.E. Relationship between the singlet-triplet splitting and the $\mathrm{Cu}-\mathrm{O}-\mathrm{Cu}$ bridge angle in hydroxo-bridged copper dimers. Inorg. Chem. 1976, 9, 2107-2110. [CrossRef]

116. Tandon, S.S.; Thompson, L.K.; Manuel, M.E.; Bridson, J.N. Magnetostructural correlations in $\mu 2-\mathrm{M} \_\mathrm{N} 3$ bridged, dinuclear copper(II) complexes. 1. Ferromagnetic and antiferromagnetic coupling associated with the azide bridge. X-ray crystal structures of $\left[\mathrm{Cu}_{2}(\mathrm{DMPTD})\left(\mu_{2}-\mathrm{N}_{3}\right)\left(\mu_{2}-\mathrm{Cl}\right) \mathrm{Cl}_{2}\right] \cdot \mathrm{CH}_{3} \mathrm{CN}$, $\left.\left[\mathrm{Cu}_{2}(\mathrm{DMPTD})\left(\mu_{2}-\mathrm{N}_{3}\right)_{2}\left(\mathrm{~N}_{3}\right)_{2}\right],\left[\mathrm{Cu}_{2}(\mathrm{DIP})\left(\mu_{2}-\mathrm{N}_{3}\right)\left(\mu_{2}-\mathrm{Cl}\right) \mathrm{Cl}_{2}\right] \cdot 0.5 \mathrm{CH}_{3} \mathrm{OH}, \quad\left[\mathrm{Cu}_{2}(\mathrm{PAP} 46 \mathrm{Me}-\mathrm{H}) \mu_{2}-\mathrm{N}_{3}\right)\left(\mathrm{N}_{3}\right)_{2}\right]$. $0.33 \mathrm{H} 2 \mathrm{O}, \quad\left[\mathrm{Cu}_{2}(\mathrm{PAP})\left(\mu_{2}-\mathrm{N}_{3}\right) \mathrm{Cl}_{3}\right] \quad \mathrm{CH}_{2} \mathrm{Cl}_{2}, \quad\left[\mathrm{Cu}_{2}(\mathrm{PAP})\left(\mu_{2}-\mathrm{N}_{3}\right)\left(\mathrm{N}_{3}\right)\left(\mathrm{NO}_{3}\right)\left(\mathrm{CH}_{3} \mathrm{OH}\right)\right] \quad\left(\mathrm{NO}_{3}\right) \mathrm{CH}_{3} \mathrm{OH}$, $\left[\mathrm{Cu}_{2}(\mathrm{PPD} 3 \mathrm{Me})\left(\mu_{2}-\mathrm{N}_{3}\right) \mathrm{Cl}_{3}\left(\mathrm{H}_{2} 0\right) \mathrm{i} . \mathrm{s}\right]$, and $\left.\left[\mathrm{Cu}_{2}(\mathrm{PPD}) \mu_{2}-\mathrm{N}_{3}\right)\left(\mathrm{NO}_{3}\right)_{3}\left(\mathrm{H}_{2} 0\right) 1.6\right]$. Inorg. Chem. 1994, 33, 5555-5570.

117. Thompson, L.K.; Tandon, S.S.; Manuel, M.E. Magneto-structural correlations in $\mu_{2}$-1,1-azide-bridged, dinuclear copper(II) complexes. Part 2. Dominant antiferromagnetic coupling with azide bridge angles exceeding $108^{\circ}$. X-ray structures of $\left[\mathrm{Cu}_{2}(\mathrm{PAP})\left(\mu_{2}-\mathrm{N}_{3}\right) \mathrm{Br}_{3}\right] \cdot \mathrm{CH}_{2} \mathrm{Cl}_{2}$, $\left[\mathrm{Cu}_{2}(\mathrm{PAP} 6 \mathrm{Me})\left(\mu_{2}-\mathrm{N}_{3}\right)\left(\mu_{2}-\mathrm{Br}\right) \mathrm{Br}_{2}\right] .1 .68 \mathrm{H}_{2} \mathrm{O},\left[\mathrm{Cu}_{2}(\mathrm{PAP} 6 \mathrm{Me})\left(\mu_{2}-\mathrm{N}_{3}\right)\left(\mu_{2}-\mathrm{H}_{2} \mathrm{O}\right)\left(\mathrm{NO}_{3}\right)_{2}\right]\left(\mathrm{NO}_{3}\right) \cdot 0.75 \mathrm{CH}_{3} \mathrm{OH}$, $\left[\mathrm{Cu}_{2}(\mathrm{PAN})\left(\mu_{2}-\mathrm{N}_{3}\right)\left(\mu_{2}-\mathrm{NO}_{3}\right)\left(\mathrm{NO}_{3}\right)_{2}\right] \cdot \mathrm{CH}_{3} \mathrm{OH} . \mathrm{CH}_{3} \mathrm{CN}$ and $\left[\mathrm{Cu}_{2}(\mathrm{PPD} 3,5 \mathrm{Me})\left(\mu_{2}-\mathrm{N}_{3}\right) \mathrm{Br}_{3} \cdot \mathrm{CH}_{3} \mathrm{OH}\right]$. Inorg. Chem. 1995, 34, 2356-2366.

118. Das, A.; Bhattacharya, K.; Das, L.K.; Giri, S.; Ghosh, A. Mixed azido/phenoxido bridged trinuclear Cu(ii) complexes of Mannich bases: Synthesis, structures, magnetic properties and catalytic oxidase activities. Dalton Trans. 2018, 47, 9385-9399. [CrossRef]

119. Lorosch, J.; Paulus, H.; Haase, W. Crystal structure and magnetic properties of a tetramer with a step-like $\mathrm{Cu}_{4} \mathrm{~N}_{4} \mathrm{O}_{2}$ core containing asymmetric bridged dimeric subunits related to the hemocyanin copper active site. Inorg. Chim. Acta 1985, 106, 101-108. [CrossRef]

120. Mallah, T.; Boillot, M.L.; Kahn, O.; Gouteron, J.; Jeannin, S.; Jeannin, Y. Crystal structures and magnetic properties of .mu.-phenolato copper(II) binuclear complexes with hydroxo, azido, and cyanato-O exogenous bridges. Inorg. Chem. 1986, 25, 3058-3065. [CrossRef]

121. Mallah, T.; Kahn, O.; Gouteron, J.; Jeannin, S.; Jeannin, Y.; Oconnor, C.J. Crystal structures and magnetic properties of dinuclear copper(II) complexes of 2,6-bis(N-(2-pyridylmethyl)formimidoyl)-4-methylphenolate with azido and cyanato-0 exogenous ligands. Inorg. Chem. 1987, 26, 1375-1380. [CrossRef]

122. Chattopadhyay, T.; Banu, K.S.; Banerjee, A.; Ribas, J.; Majee, A.; Nethaji, M.; Das, D. A novel single pot synthesis of binuclear copper(II) complexes of macrocyclic and macroacyclic compartmental ligands: Structures and magnetic properties. J. Mol. Struct. 2007, 833, 13-22. [CrossRef]

123. Kahn, O.; Mallah, T.; Gouteron, J.; Jeannin, S.; Jeannin, Y. Low-lying electronic states in $\mu$-phenolato copper(II) binuclear compounds with hydroxo, ethanolato, azido, and cyanato exogenous bridges: Crystal structures, magnetic properties, and interpretations. J. Chem. Soc. Dalton Trans. 1989, 1117-1126. [CrossRef]

124. Cheng, P.; Liao, D.; Yan, S.; Jiang, Z.; Wang, G.; Yao, X.; Wang, H. Magnetic interaction in the keto and enol forms of binuclear copper (II) complexes with a Robson-type ligand. X-ray crystal structure of [Cu $2(\mathrm{HL})$ $\left(\mu-\mathrm{N}_{3}\right)\left(\mathrm{H}_{2} \mathrm{O}\right)\left(\mathrm{C}_{2} \mathrm{H}_{5} \mathrm{OH}\right)\left(\mathrm{ClO}_{4}\right)$ ]. Inorg. Chim. Acta 1996, 248, 135-137. [CrossRef]

125. Karlin, K.D.; Farooq, A.; Hayes, J.C.; Cohen, B.I.; Rowe, T.M.; Sinn, E.; Zubieta, J. Models for met-hemocyanin derivatives: Structural and spectroscopic comparisons of analogous phenolate and $\mathrm{X}\left(\mathrm{X}=\mathrm{OH}^{-}\right.$, $\mathrm{OMe}^{-}, \mathrm{N}_{3}^{-}, \mathrm{Cl}^{-}, \mathrm{OAc}^{-}, \mathrm{OBz}^{-}$) doubly bridged dinuclear copper (II) complexes. Inorg. Chem. 1987, 26, 1271-1280. [CrossRef]

126. Banerjee, A.; Singh, R.; Colacio, E.; Rajak, K.K. Binuclear copper(II) chelates with heptadentate ligands: Synthesis, structure, magnetic properties, DFT studies, and catecholase and hydrolytic DNA cleavage activity. Eur. J. Inorg. Chem. 2009, 2009, 277-284. [CrossRef]

127. Fallah, M.S.E.; Badyine, F.; Vicente, R.; Escuer, A.; Solans, X.; Bardia, M.F. Complementarity and countercomplementarity in polynuclear copper(II) complexes with $\mathrm{R}_{2} \mathrm{NCH}_{2} \mathrm{CH}(\mathrm{OH}) \mathrm{CH}_{2} \mathrm{NR}_{2}(\mathrm{R}=\mathrm{H}$, $\mathrm{CH}_{3}$ ): Crystal structures and magnetic study. Dalton Trans. 2006, 2934-2942. [CrossRef] [PubMed] 
128. Nishida, Y.; Kida, S. Crystal structures and magnetism of binuclear copper(II) complexes with alkoxide bridges. Importance of orbital complementarity in spin coupling through two different bridging groups. J. Chem. Soc. Dalton Trans. 1986, 2633-2640. [CrossRef]

129. Ruiz, E.; Alemany, P.; Alvarez, S.; Cano, J. Structural modeling and magneto-structural correlations for hydroxo-bridged copper(II) binuclear complexes. Inorg. Chem. 1997, 36, 3683-3688. [CrossRef]

130. Ruiz, E.; Cano, J.; Alvarez, S.; Alemany, P. Magnetic coupling in end-on azido-bridged transition metal complexes: A density functional study. J. Am. Chem. Soc. 1998, 120, 11122-11129. [CrossRef]

131. Macrae, C.F.; Sovago, I.; Cottrell, S.J.; Galek, P.T.A.; McCabe, P.; Pidcock, E.; Platings, M.; Shields, G.P.; Stevens, J.S.; Towler, M.; et al. Mercury 4.0: From visualization to analysis, design and prediction. J. Appl. Cryst. 2020, 53, 226-235. [CrossRef]

132. Ullman, F.; Brittner, K. Ther die herstellung von oxyuvitinaldehyd aue p-kresol. Chem. Ber. 1909, 42, 2539-2549. [CrossRef]

133. Bruker. APEX3; Bruker AXS, Inc. Analytical X-Ray Systems: Madison, WI, USA, 2018.

134. Bruker. SAINT, Version 6.45A; Bruker AXS, Inc. Analytical X-Ray Systems: Madison, WI, USA, 2003.

135. Sheldrick, G.M. Crystal structure solution with ShelXT. Acta Cryst. A 2015, 71,3-8. [CrossRef] [PubMed]

136. Bruker. SHELXTL V6.12; Bruker AXS, Inc. Analytical X-Ray Systems: Madison, WI, USA, 2002.

137. Dolomanov, O.V.; Bourhis, L.J.; Gildea, R.J.; Howard, J.A.K.; Puschmann, H. OLEX2: A complete structure solution, refinement and analysis program. J. Appl. Cryst. 2009, 42, 339-341. [CrossRef]

Sample Availability: Samples of the compounds 1-6 are available from the authors.

Publisher's Note: MDPI stays neutral with regard to jurisdictional claims in published maps and institutional affiliations.

(C) 2020 by the authors. Licensee MDPI, Basel, Switzerland. This article is an open access article distributed under the terms and conditions of the Creative Commons Attribution (CC BY) license (http://creativecommons.org/licenses/by/4.0/). 